DILLIAN ADELAINE CESAR DA SILVA

PUBLICIDADE DE ALIMENTOS PARA CRIANÇAS E ADOLESCENTES: DESVELAR DA PERSPECTIVA ÉTICA NO DISCURSO DO CONSUMO CONSCIENTE E INFORMADO 


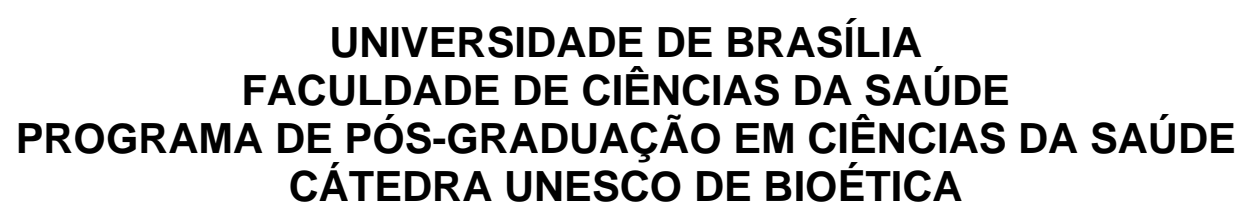

DILLIAN ADELAINE CESAR DA SILVA

PUBLICIDADE DE ALIMENTOS PARA CRIANÇAS E ADOLESCENTES:

DESVELAR DA PERSPECTIVA ÉTICA NO DISCURSO DO CONSUMO

CONSCIENTE E INFORMADO

Dissertação apresentada como requisito parcial para a obtenção do Título de Mestre em Bioética pelo Programa de Pós-Graduação em Bioética da Universidade de Brasília. Orientador: Prof. Dr. Antonio Carlos Rodrigues da Cunha 


\title{
PUBLICIDADE DE ALIMENTOS PARA CRIANÇAS E ADOLESCENTES: DESVELAR DA PERSPECTIVA ÉTICA NO DISCURSO DO CONSUMO CONSCIENTE E INFORMADO
}

\author{
Dissertação apresentada como requisito parcial \\ para a obtenção do Título de Mestre em Bioética \\ pelo Programa de Pós-Graduação em Bioética da \\ Universidade de Brasília.
}

Brasília, em 26/02/2016,

BANCA EXAMINADORA:

Prof. Dr. Antonio Carlos Rodrigues da Cunha (Presidente)

Universidade de Brasília

Profa. Dra. Caroline Filla Rosaneli (Membro Externo)

Pontifícia Universidade Católica do Paraná

Prof. Dr. Wanderson Flor do Nascimento (Membro Interno)

Universidade de Brasília

Profa. Dra. Ceres Nunes de Resende Oyama (Suplente) Universidade de Brasília 


\section{AGRADECIMENTOS}

À família de origem, muito especialmente à mãe-referência ética, Leticia, que fez "das tripas, coração" para que eu tivesse oportunidades na vida;

Ao companheiro Ricardo e ao filhote Giordano, que eu possa retribuir, diariamente e com todo meu carinho, o amor tranquilo, a paciência e o suporte na caminhada de estudos;

Ao professor doutor Rodrigues, pelo apoio e paciência na orientação do trabalho de pesquisa;

Aos professores e aos colegas da UnB, pelo mundo que se abriu com o aprendizado e pelo apoio diante dos desafios;

Aos colegas e chefes da Gerência de Nutrição e da Diretoria de Vigilância Sanitária da SES-DF, por apoiarem minha empreitada e compartilharem a construção do SUS que almejamos;

Às colegas Alejandra e Ana Virginia, e ao professor doutor Patrick Dahlet, pelas fundamentais contribuições na análise do discurso;

Aos amigos que apoiam e incentivam, de perto e de longe, cada um a seu modo, "desde sempre": Alessandra Coelho, Anelise, Bárbara, Elisa Piccinini, Fátima, Juliana Albuquerque, Luciene, Marina, Mônica, Sellene, Tatiana Barros, Thatiana Fávaro; aos "Éticos negativos" com quem venho compartilhando ideais e vivências: André, Andrea, Carol; ao Damião e ao Carlos, pelo "empurrão" definitivo: vá "fazer" mestrado, menina!;

Aos trabalhadores que pagam pela educação pública no país, nem sempre tendo pleno acesso a ela. 


\section{RESUMO}

Um dos públicos de maior interesse para a publicidade de alimentos é o infantil, visto pela indústria de marketing não apenas como futuros, mas como atuais consumidores. Por outro lado, crianças e adolescentes são extremamente vulneráveis à publicidade de alimentos, que, sabidamente, influencia as escolhas alimentares. Considerando ainda o perfil epidemiológico e nutricional da população brasileira, a regulação da publicidade de alimentos pode assumir papel estratégico como medida de proteção à saúde. Tendo em conta diferentes formas de olhar para a questão como problema, o objetivo dessa pesquisa foi caracterizar a perspectiva ética presente no discurso contrário à regulação, pelo Estado, da publicidade de alimentos direcionada a crianças e adolescentes - denominado no âmbito desse estudo "discurso do consumo consciente e informado" - com fins de compreender o contexto de produção e a maneira pela qual o discurso gera sentidos. A metodologia adotada foi qualitativa, com análise documental e utilização de conceitos, ferramentas e procedimentos da Análise de Discurso. As lentes que pautaram a análise e a discussão foram o pensamento de Hans Jonas e seu Princípio Responsabilidade e a Bioética de Intervenção, de Garrafa e Porto. A análise do discurso do consumo consciente e informado caracterizou uma perspectiva ética em que predominam relações de consumo sobre a vulnerabilidade de crianças e adolescentes. É constante o excesso de retórica, o uso de afirmações e premissas não discutidas, e uma forma discursiva pautada por recursos de naturalização, inverossimilidade, dissimulação ideológica e eufemização. Estão presentes o apagamento dos conflitos sociais, a desvalorização de perspectivas históricas e o ocultamento da enunciação. O discurso não se alinha ao princípio da responsabilidade de Hans Jonas nem aos princípios da bioética de intervenção, em especial a proteção aos vulneráveis. As propostas de autorregulamentação tampouco são convergentes para a ampliação da autonomia para escolhas alimentares. Considera-se, por fim, que a perspectiva ética do discurso analisado representa um duplo paradoxo, por tratar-se de discurso empresarial, mas que apaga seu 
enraizamento competitivo e metamorfosa-se em discurso ético, buscando a visualização e recepção como tal.

PALAVRAS-CHAVE: publicidade de alimentos; crianças e adolescentes; discurso; vulnerabilidade; ética. 


\begin{abstract}
When it comes to food marketing, children are one of the greatest targets. They are seen by the marketing industry not only as future consumers, but also as current ones. On the other hand, children are extremely vulnerable to food publicity, and it is broadly recognized that it influences food choices. Considering Brazilian population's nutrition and epidemiological status as well, regulatory actions over food marketing directed to children can play a strategic role as a health protection measure. Taking into account different ways to look at the question as a problem, the objective of this research was to characterize the ethical perspective present in the discourse against the regulatory actions over food marketing directed to children - in the research's context, called "informed and conscious consumption's discourse". The final goal is to realize the means of production and the way through which the discourse creates meanings. The methodology adopted was qualitative, with documental analysis and use of concepts, tools and procedures based on the Discourse Analysis. The lens that oriented the analysis and discussion were Hans Jonas' thinking and his Responsibility Principle and the Intervention Bioethics, from Garrafa and Porto. The informed and conscious consumption's discourse analysis showed an ethical perspective in which the consumption relations over the children's vulnerability predominates. The rhetorical excess is constant, as well as the use of statements and non-discussed premises, and a discursive form guided by naturalization resources, untruthfulness, ideological dissimulation and euphemism. The social conflicts deletion, ahistorical perspective and the enunciation concealment are also present. The discourse does not align with Hans Jonas' Responsibility Principle or with the Intervention Bioethics' principles, specially the vulnerability protection. Neither are the self-regulation proposals convergent to autonomy's extension with the objective of making food choices. Lastly, it is considered that the ethical perspective of the analyzed discourse represents a double paradox, because it is a business discourse. However, it deletes its competitive roots and metamorphoses itself into an ethical discourse, aiming at the visualization and reception as such.
\end{abstract}

KEY WORDS: food marketing; children; discourse; vulnerability; ethics. 


\section{LISTA DE ABREVIATURAS E SIGLAS}

ABA - Associação Brasileira de Anunciantes

ABAP - Associação Brasileira de Agências de Propaganda

ABTA - Associação Brasileira de Televisão por Assinatura

ABERT - Associação Brasileira de Emissoras de Rádio e Televisão

AD - Análise de Discurso

ANER - Associação Nacional de Editores de Revistas

ANJ - Associação Nacional de Jornais

ANVISA - Agência Nacional de Vigilância Sanitária

CONANDA - Conselho Nacional dos Direitos da Criança e do Adolescente

CONAR - Conselho Nacional de Autorregulamentação Publicitária

CONSEA - Conselho Nacional de Segurança Alimentar e Nutricional

DCNT - Doenças Crônicas Não Transmissíveis

DHAA - Direito Humano à Alimentação Adequada

DUBDH - Declaração Universal sobre Bioética e Direitos Humanos

FENEEC - Federação Nacional das Empresas Exibidoras Cinematográficas

IAB Brasil - Interactive Advertising Bureau

IBGE - Instituto Brasileiro de Geografia e Estatística

LOSAN - Lei Orgânica de Segurança Alimentar e Nutricional

NBCAL - Norma Brasileira de Comercialização de Alimentos para Lactentes e

Crianças de primeira infância, Bicos, Chupetas e Mamadeiras

OMS - Organização Mundial da Saúde

ONU - Organização das Nações Unidas

OPAS - Organização Pan-Americana da Saúde

PNSAN - Política Nacional de Segurança Alimentar e Nutricional

POF - Pesquisa sobre Orçamentos Familiares

RDC - Resolução de Diretoria Colegiada

SAN - Segurança Alimentar e Nutricional

SISAN - Sistema Nacional de Segurança Alimentar e Nutricional

SUS - Sistema Único de Saúde

UnB - Universidade de Brasília

UNESCO - Organização das Nações Unidas para a Educação, a Ciência e a

Cultura

VIGITEL - Vigilância de Fatores de Risco e Proteção para Doenças Crônicas por Inquérito Telefônico 


\section{SUMÁRIO}

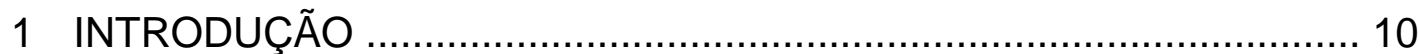

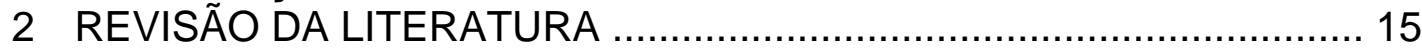

2.1 Segurança Alimentar e Nutricional, Direito Humano à Alimentação Adequada e Ética ……............................................................. 15

2.2 Regulação de Publicidade de alimentos no Brasil - Por quê?.....18

2.3 Vulnerabilidade, autonomia e escolhas alimentares? ................ 23

2.4 A Responsabilidade do Estado na Regulação ……………....... 26

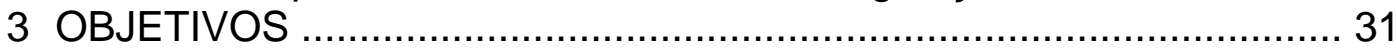

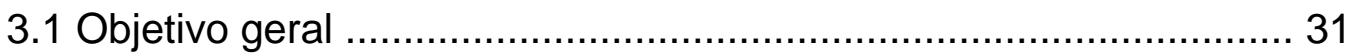

3.2 Objetivos específicos .......................................................... 31

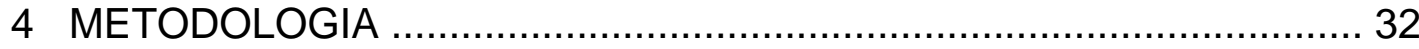

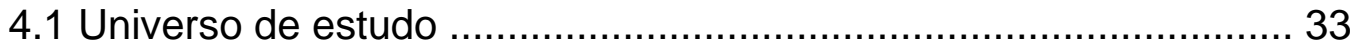

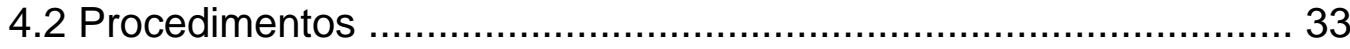

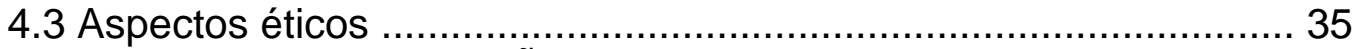

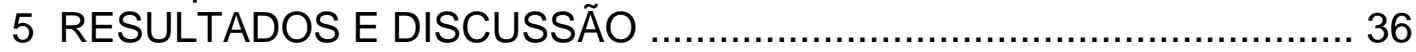

$5.1 \mathrm{O}$ discurso do consumo consciente e informado ............................ 36

5.1.1 Primeira Seção - O Conar reflete de forma democrática, ética e técnica os anseios da sociedade em questões que envolvam o consumo e a publicidade. 39

5.1.2 Segunda Seção - A publicidade brasileira é uma atividade que traz a ética em seu DNA ........................................................... 48 5.1.3 Terceira Seção - O sistema misto de legislação e autorregulamentação provê a segurança que convém ao consumidor 52

5.1.4 Quarta Seção - A solução para a epidemia de obesidade infantil passa pela família, educação - e também pela autorregulamentação

5.1.5 Quinta Seção - Uma breve história do Conar ......................... 57

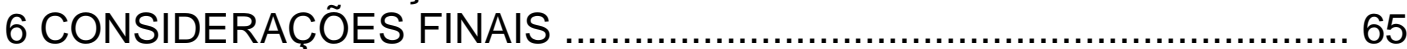

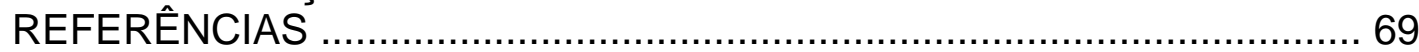

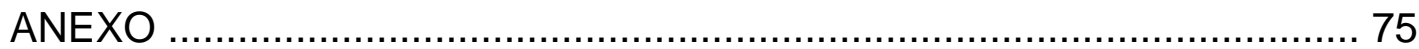




\section{INTRODUÇÃO}

Das biociências e das tecnologias, a bioética tem o motor que sem descanso Ihe oferece propósitos, estímulos, demandas; não quaisquer demandas, mas demandas urgentes e importantes. Importância não apenas justificada por seus propagadores e estudiosos, mas vulgarizada pela informação massiva e popularizada por uma sociedade que se vê entre risco e vulnerabilidade (Ramos, 2012, p. 143) ${ }^{1}$.

O debate em torno do controle da publicidade no Brasil envolve o Estado, em seu papel de proteção da população; os movimentos sociais, que buscam a garantia de direitos; e as empresas do setor regulado - tanto as produtoras de bens submetidos ao controle como o setor de publicidade e propaganda ${ }^{2}$ - que defendem a liberdade de atuação, através de mecanismos de autorregulamentação, como a atuação do Conselho Nacional de Autorregulamentação Publicitária (Conar).

Um dos públicos em que há maior interesse em conquistar, por meio da promoção comercial, é o público infantil, não apenas futuros como atuais consumidores, como são vistos pela indústria de marketing.

Crianças e adolescentes são considerados extremamente vulneráveis aos apelos promocionais em formatos os mais diversos veiculados em diferentes meios de comunicação, e a propaganda, a publicidade e a promoção de alimentos influenciam as escolhas alimentares infantis ${ }^{3}$.

Tendo em conta o perfil epidemiológico e nutricional da população, a vulnerabilidade e a escassez de autonomia para a realização de escolhas alimentares, esforços no sentido de fazer frente à influência da publicidade de alimentos iniciaram-se no Brasil há menos de uma década, quando em 2010 o Ministério da Saúde e a Agência Nacional de Vigilância Sanitária (Anvisa) elaboraram e publicaram uma Resolução de Diretoria Colegiada da Anvisa (RDC), a RDC-Anvisa $\mathrm{n}^{0} 24$ de $2010^{4}$, com o objetivo de regular a propaganda e outros tipos de estratégias de promoção comercial de alimentos, cumprindo a 
Anvisa com seu papel regulador de uma prática comercial que, sabidamente, têm influência no perfil alimentar da população.

No entanto, a presença de interesses contrários à regulação e ao controle por parte do Estado, levou ao fracasso desse processo, vez que, em sequência à publicação do instrumento, entidades representativas do setor regulado pressionaram o governo pela invalidação da RDC $n^{0} 24$ de 2010, alegando incapacidade da Anvisa como reguladora, justificando que tal medida somente poderia ser implementada por Lei.

Desde então, uma série de Projetos de Lei vêm sendo elaborados, com diferentes focos e diferentes origens de iniciativa, na tentativa de preencher a lacuna relativa ao controle de publicidade direcionada a crianças $e$ adolescentes, nenhum deles tendo sido encaminhado até instâncias necessárias à aprovação como Lei até o momento.

Diversos movimentos sociais têm buscado chamar atenção para a necessidade de regulação da publicidade, desde o fracasso da RDC 24 de 2010, alguns, inclusive entendendo que a publicidade voltada a crianças deva ser proibida. Em março de 2014, o Conselho Nacional dos Direitos da Criança e do Adolescente (Conanda), órgão ligado à Secretaria de Direitos Humanos da Presidência da República, aprovou a Resolução 163/2014 ${ }^{5}$, que considerou abusiva toda e qualquer publicidade dirigida à criança, proibindo-a, em acordo com o Código de Defesa do Consumidor, que impede a publicidade com tal característica. Apesar de seu caráter como norma vinculante, a Resolução do Conanda não é respeitada pelos anunciantes, que seguem impunemente violando-a.

Após a publicação da Resolução em referência pelo Conanda, o conjunto das entidades que congregam a categoria econômica de comunicação social - associações representantes de anunciantes, agências de publicidade, emissoras de rádio e televisão, revistas e outdoors - veio a público, por meio de nota divulgada em seu sítio eletrônico ${ }^{6}$, afirmar que somente reconheciam o Poder Legislativo, como único foro capaz de, legitimamente, legislar sobre 
publicidade comercial e que a autorregulamentação, vigente no Brasil, seria eficiente e suficiente para controlar publicidade abusiva.

Por outro lado, garantir o acesso a uma alimentação adequada e saudável é responsabilidade do Estado, e deve ser direito apropriado pela sociedade, entendimento que se fortalece no país desde a inclusão, em 2010, da alimentação como direito humano no rol dos direitos sociais da Constituição Brasileira.

Isso posto, urge debater e dar encaminhamento adequado a situações como a persistente falta de acesso aos alimentos por parcela da população; e questões que mais recentemente têm ocupado a pauta da área da nutrição em saúde, que dizem respeito à qualidade dos alimentos e ao modo como fazemos escolhas alimentares. Tais questões vêm sendo enfrentadas por meio de ações instituídas no âmbito da Política Nacional de Segurança Alimentar e Nutricional (PNSAN), que tem como base a intersetorialidade das políticas públicas.

Assuntos da pauta da PNSAN como regulação da publicidade de alimentos direcionada a crianças, da oferta de alimentos pouco nutritivos nas cantinas escolares, passando pela regulação da composição e da rotulagem nutricional de alimentos industrializados, chegando a temas como agrotóxicos e alimentos geneticamente modificados, requerem discussão sob o olhar da Bioética, tomando como base seus referenciais conceituais, princípios e critérios.

Refletindo sobre tal cenário, é importante aprofundar o conhecimento sobre a vulnerabilidade dos públicos a que se dirige a publicidade de alimentos e como se dão escolhas verdadeiramente autônomas, para fins de discutir a questão das responsabilidades envolvidas, e de como essas responsabilidades são concebidas, sob uma perspectiva ética, por parte de quem produz e veicula campanhas publicitárias destinadas a crianças e adolescentes.

Sabendo-se da existência de diferentes perspectivas ou formas de olhar para a questão da regulação da publicidade de alimentos para crianças e adolescentes como um problema, esse trabalho se propôs a analisar o discurso 
reputado como contrário à regulação, por parte do Estado, da publicidade de alimentos. O material de análise do discurso foi extraído de um documento elaborado pelo Conar e publicado em seu site em 2012. Como balizadores da discussão, foram utilizados o pensamento de Hans Jonas e seu Princípio Responsabilidade e a Bioética de Intervenção, de Garrafa e Porto.

A defesa dos Direitos Humanos à saúde e à alimentação adequada encontra nos marcos da Bioética de Intervenção e do Princípio Responsabilidade pleno respaldo e congruência, especialmente no que tange à compreensão sistêmica e transdisciplinar da realidade, à responsabilidade pública na defesa dos mais vulneráveis, ao diálogo plural e ao dever com as gerações futuras como imperativos e tantas outras interfaces, permitindo o religar de saberes.

No cenário da saúde pública e da Segurança Alimentar e Nutricional (SAN), é de extrema relevância desenhar e implementar políticas públicas intersetoriais, transdisciplinares, equânimes e efetivas voltadas à prevenção e ao enfrentamento das doenças crônicas não transmissíveis (DCNT), entre elas a obesidade. $\mathrm{O}$ alarmante aumento da prevalência dessas doenças nas últimas décadas caracterizou alterações no perfil epidemiológico e nutricional da população brasileira, implicado pelas drásticas mudanças nos modos de vida, padrões de atividade física e hábitos alimentares, em decorrência dos processos de industrialização, urbanização e globalização ${ }^{7}$.

Tal panorama epidemiológico exige atuação do Estado no sentido de proteger a população dessas doenças, o que passa pela prevenção da obesidade ainda na infância; nesse sentido, tem-se demonstrado, dentre tantos outros fatores, a influência nefasta da publicidade de alimentos nas escolhas alimentares das famílias, em especial as escolhas realizadas pelas crianças e adolescentes $^{3,8}$.

Nesse contexto, a regulação da propaganda e da publicidade de alimentos pode assumir um papel estratégico como medida de proteção, 
particularmente voltada para o grupo mais vulnerável aos apelos promocionais, como o infantil ${ }^{8,9,10,11,12}$.

Esse entendimento encontra reforço no arcabouço Constitucional Brasileiro, que define a saúde como direito de todos e dever do Estado, a alimentação adequada também como direito social, além de diversos outros documentos legais que expressam obrigações do Estado no sentido de proteger, promover e garantir a saúde e a nutrição adequada no país ${ }^{13,14,15}$.

Percebe-se a urgência de uma atuação que se mostre responsável e comprometida com a proteção às crianças e adolescentes, vulneráveis à publicidade de alimentos, considerando também o perfil epidemiológico e nutricional da população brasileira como orientador das práticas em saúde. A presença de discursos sociais conflitantes com essa lógica dificulta o avanço e requer, conforme apontam estudos recentes, análise à luz de parâmetros éticos, tendo-se em conta questões como o direito à informação e à saúde, a necessidade de minimizar os riscos implicados na exposição às práticas publicitárias e priorizar o interesse público em detrimento dos interesses de natureza econômica ${ }^{12,16,17}$.

Com a análise proposta, pretende-se identificar o alinhamento ou não do discurso presente no texto do documento aos mecanismos de proteção aos vulneráveis e reforço da sua autonomia para escolhas alimentares saudáveis, buscando-se compreender como se dá a construção da perspectiva ética presente no discurso - aqui identificado como discurso do consumo consciente e informado - e, por outro lado, entendendo-se que a autorregulamentação seja insuficiente, logo, que seja eticamente legítimo, defensável e, ainda, mandatário ao Estado regular a publicidade de alimentos. 


\section{REVISÃO DE LITERATURA}

\subsection{SEGURANÇA ALIMENTAR E NUTRICIONAL, DIREITO HUMANO À ALIMENTAÇÃO ADEQUADA E ÉTICA}

Esta seção pontua conceitos e referências básicos em apoio à análise do discurso pretendida, buscando-se entrelaçar os temas nominados.

O debate sobre SAN no Brasil teve início com a perspectiva de enfrentamento da fome e da desnutrição como sua expressão biológica. Josué de Castro abordou a fome como socialmente determinada, requerendo políticas públicas para seu enfrentamento como problema complexo e multifacetado. De acordo com Pinheiro e Carvalho ${ }^{18}$, a reestruturação do Conselho Nacional de Segurança Alimentar e Nutricional (Consea) e a publicação da Lei Orgânica de Segurança Alimentar e Nutricional (Losan) foram marcos fundamentais para a ampliação do debate do combate à fome para o discurso da SAN, conduzindo à discussão e à instituição de um Sistema Nacional de Segurança Alimentar e Nutricional (Sisan).

Ao longo da trajetória de mobilização e empreendimento de ações na área, reforçou-se a perspectiva que trata a alimentação e a nutrição como duas faces da insegurança alimentar e nutricional, direcionando a construção de políticas públicas intersetoriais para o alcance da SAN e a garantia do Direito Humano à Alimentação Adequada (DHAA), previstos, respectivamente, no âmbito da PNSAN e da Constituição Federal, tornando objetiva a responsabilidade do Estado em promover práticas alimentares saudáveis.

Para Pinheiro e Carvalho ${ }^{18}$, a alimentação adequada e saudável, para além dos aspectos de saúde, deve ser valorizada e reconhecida em suas dimensões cultural, regional e na concretude da categoria comida. A $5^{a}$ Conferência Nacional de Segurança Alimentar e Nutricional, realizada em novembro de 2015 em Brasília, trouxe como tema "Comida de Verdade no 
Campo e na Cidade", buscando estabelecer o entendimento de que essa categoria se constrói como forma concreta de reconhecimento do que seja uma alimentação adequada e saudável e que pauta as escolhas alimentares.

As escolhas alimentares são condicionadas pelo modelo de produção e oferta de alimentos, que por sua vez envolve elementos como a disponibilidade, o abastecimento, a comercialização e o acesso, entre outros, determinando, por fim, a maneira como nos alimentamos ${ }^{18}$. Entre esses elementos que influenciam a realização de escolhas, estão as práticas publicitárias, como anteriormente mencionado no âmbito deste trabalho.

Pensar em um modelo de organização social e econômica que seja capaz de garantir o Direito Humano à Alimentação Adequada requer práticas de produção e consumo que sejam pautadas pela eticidade e responsabilidade com o futuro, ponderando o compartilhamento da vida entre os seres humanos e as demais formas de vida no planeta.

Para apoiar a construção dessa perspectiva de modos de vida sustentável e responsável no campo da alimentação, apresentam-se, a seguir, breves pontos tomados em conta por este trabalho como parte do debate sobre ética.

Adela Cortina ${ }^{19}$, em seu livro Ética, historicia que a palavra ética tem origem do grego ethos, cujo sentido era de morada ou o lugar em que se vive, tendo seu significado se modificado para caráter ou modo de ser. A respeito de uma possível tentativa de diferenciação entre os termos ética e moral, a autora apresenta que o segundo termo vem do latim mores que originariamente significava costume, passando em seguida a ter como significado modo de ser, caráter. Assim, Cortina nos mostra que as duas palavras têm sentidos iguais, embora, no contexto acadêmico, o termo ética refira-se à filosofia moral, como saber reflexivo acerca da dimensão da ação humana, enquanto o termo moral apontaria para os diversos códigos morais existentes ${ }^{19}$.

Hans Jonas ${ }^{20}$ faz referência à ética até os dias atuais como "[...] injunção direta para fazer ou não fazer certas coisas ou como determinação dos 
princípios de tais injunções [...]" (2006, p. 29) e constrói uma linha de argumentação focada na necessidade de atualizar pressupostos com a perspectiva de que as modificações na natureza do agir humano requerem também mudanças na ética, refletindo sobre o modo como a técnica moderna afeta a natureza da ação dos seres humanos entre si e com o meio e implicando uma nova dimensão para a ética, a da responsabilidade.

Segre e Cohen ${ }^{21}$ entendem a ética como uma condição de percepção da existência de conflitos entre a emoção e a razão, com consequente posicionamento coerente face a tais conflitos. Assim, a ética requer, em uma visão mais individual, consciência, autonomia e coerência.

Para Wittgenstein ${ }^{22}$, não existe a possibilidade de um discurso universal a respeito de Ética; em uma interessante conferência sobre o tema, ele trabalha a partir da referência a um conceito de George Moore, definindo que ética seria a investigação a respeito do que é bom, e acrescenta que se poderia, ainda, dizer que ética é investigação sobre o que é valioso, sobre o que realmente importa ou sobre o correto modo de viver.

Com base em tais referências, para apurar o entendimento, seria necessário recorrer à metaética, debatida por Andrew Fisher ${ }^{23}$ como área da filosofia que apresenta questionamentos sobre as condições das afirmações éticas, perguntando: com o que o discurso ético está comprometido? Como se define o conceito de moral frente a outros raciocínios, como a prudência e a etiqueta, por exemplo? Como funciona o uso semântico da linguagem moral ao definir o que é "bom"? Como se dá a natureza vinculante e a justificação da moral?

Para fins do presente estudo, utilizaremos como orientadora a seguinte questão: com o quê está comprometido o discurso ético contrário à regulação da publicidade de alimentos? Adicionalmente, servirão como guias os referenciais mencionados e adiante explicitados, da Bioética de Intervenção e da Ética de Responsabilidade. 


\subsection{REGULAÇÃO DA PUBLICIDADE DE ALIMENTOS NO BRASIL - POR QUÊ?}

Para discutir a regulação da publicidade de alimentos, buscou-se conceituar o termo, trazendo referencial adotado por Eloá Muniz ${ }^{24}$, especialista da área de comunicação. A autora apresenta levantamento histórico do conceito, que inicialmente, até o advento da industrialização, referia-se à informação ao público sobre produtos existentes, sem incitação à compra. Em um segundo momento, conforme definição, evoluiu-se para pesquisa de interesses do público como forma de orientar a publicidade, que a partir de então, tornou-se sugestiva. Um terceiro período constituiu-se como evolução das técnicas publicitárias, com apoio não só em estudos de mercado, mas também na psicologia social, na sociologia e na psicanálise, buscando atuar sobre as motivações inconscientes do público e incidir em suas atitudes de compra.

Muniz afirma que "a publicidade contemporânea mitifica e converte em ídolo o objeto de consumo, revestindo-o de atributos que frequentemente ultrapassam as suas próprias qualidades e a sua própria realidade" (Muniz, 2004 , p. 2$)^{24}$.

Eugênio Malanga ${ }^{25}$ apresenta como definição de publicidade a que segue: "[...] conjunto de técnicas de ação coletiva no sentido de promover o lucro de uma atividade comercial, conquistando, aumentando e mantendo clientes" (Malanga, 1979, p. 11) ${ }^{25}$. O mesmo autor traz ainda que a publicidade possui finalidade essencialmente lucrativa, é paga pelo consumidor proporcionalmente aos produtos que adquire e frequentemente apela para 0 instinto de conservação e sentimentos de conforto e prazer.

Posto tal entendimento de publicidade, passamos a examinar o tema da regulação, enquanto ação realizada pelo Estado, mais especificamente a regulação em saúde. 
Ao estudar discursos presentes no processo de regulação da composição nutricional dos alimentos no país, Figueiredo ${ }^{26}$ debate acerca da regulação em saúde como processo de gestão dos riscos envolvidos no consumo de produtos e serviços de interesse à saúde.

A autora entende que a intervenção do Estado sobre as práticas produtivas é um imperativo no sentido de proteger a saúde pública, especialmente quando se trata de atividades privadas que podem gerar riscos. Assim, a regulação sanitária:

[...] pressupõe sempre a conjugação do conhecimento técnico multidisciplinar com o posicionamento político, e reveste-se de vários componentes que extrapolam o ato fiscalizatório de caráter privativo do Estado sobre os objetos de interesse à saúde propriamente dita (Figueiredo, 2014, p. 27-28) ) $^{26}$.

A regulação sanitária engloba diversos âmbitos de atuação, como regulamentação, investigação, fiscalização, monitoramento, controle, auditoria e avaliação, medidas adotadas pelo Estado no processo de gestão do risco à saúde ${ }^{26}$.

Destaque-se, ainda, o apontamento de que o processo de regulação envolve diferentes sujeitos que representam interesses também diversos, onde entram em confronto os conhecimentos científicos, os posicionamentos ideológicos e políticos presentes na esfera social:

Utilizada para ajustar as práticas do mercado, essa é a forma de exigir a adoção de medidas de prevenção e de controle dos riscos dos produtos e serviços ofertados à sociedade, assim como, de aplicar sanções e penalidades quando da existência de descumprimentos ou desvios das regras definidas (Figueiredo, 2014, p. 29) ${ }^{26}$.

Sabendo-se da relevância da questão alimentar e nutricional como componente da saúde, entende-se ser necessário ampliar a avaliação das ações regulatórias na área no que diz respeito à exposição à publicidade e sua relação com o perfil alimentar e nutricional da população brasileira.

Estudos compilados em relatório da Organização Mundial da Saúde (OMS) sobre publicidade de alimentos demonstraram a ocorrência de 
exposição excessiva de crianças à publicidade de alimentos, principalmente alimentos não saudáveis (ricos em calorias, gorduras, açúcares e sódio) - que constituem $90 \%$ dos produtos anunciados - com especial destaque às mídias televisivas $^{8}$.

Essa exposição exerce influência nos hábitos de consumo e no estado nutricional do público a que são dirigidas, conforme também vêm demonstrado vários documentos a respeito da temática ${ }^{3,27,28}$.

Consequências da influência da publicidade de alimentos pouco saudáveis nos hábitos alimentares expressam-se no perfil epidemiológico da população. Embora apresentando estabilização nas tendências de crescimento do excesso de peso e obesidade, os dados de 2014 da pesquisa de Vigilância de Fatores de Risco e Proteção para Doenças Crônicas por Inquérito Telefônico (VIGITEL) ${ }^{29}$, realizada anualmente pelo Ministério da Saúde, mostram que $52,5 \%$ da população brasileira adulta apresentam excesso de peso, um crescimento de $23 \%$ em nove anos de pesquisa, e $17,9 \%$ apresentam obesidade. Dados mais recentes disponíveis em relação a crianças e adolescentes são provenientes da Pesquisa sobre Orçamentos Familiares (POF) do Instituto Brasileiro de Geografia e Estatística (IBGE) POF/IBGE 2008/2009 ${ }^{30}$ : 33,5\% das crianças de 5 a 9 anos apresentam excesso de peso e 14,3\% apresentam obesidade. Entre os adolescentes, de 10 a 19 anos, 20,5\% estão em sobrepeso e 4,9\% apresentam obesidade.

Para além do impacto social da obesidade, o custo econômico poderia servir como reforço a justificativa de medidas interventivas mais fortes por parte do Estado em seus determinantes. Recente pesquisa ${ }^{31}$ a respeito do impacto econômico da obesidade no Sistema Único de Saúde (SUS) demonstrou que foram gastos em 2011, R\$ 488 milhões (quatrocentos e oitenta e oito milhões de Reais) com o tratamento da obesidade e de doenças associadas a esse quadro.

Outro estudo recente ${ }^{32}$, de amplitude internacional, divulgado por meio do site Criança e Consumo, apontou que o custo com a obesidade representa 
cerca de 2,4\% do PIB nacional, o que significa 110 bilhões de Reais, incluindose no cálculo custos com a queda de produtividade, gastos diretos com saúde e os investimentos que seriam necessários à redução dos impactos da obesidade.

Por outro lado, os setores sujeitos à regulação da publicidade entendem que a autorregulamentação de publicidade seja suficiente, e colocam que a responsabilidade individual dos pais e famílias deve ter maior peso na realização das escolhas alimentares. Também defendem a publicidade como meio informativo sobre os alimentos ${ }^{33}$.

Em meio a tal cenário conflituoso, organismos internacionais apontam para a necessidade de medidas urgentes para regular a atividade publicitária na área de alimentos voltada para crianças e adolescentes ${ }^{8,9,10}$. Observa-se, para além da questão nutricional, que os impactos dessa atividade têm efeitos negativos no âmbito dos direitos Sociais e Culturais, entendendo que as empresas devem garantir que suas comunicações não impactem negativamente os direitos das crianças e que se utilize o marketing para aumentar a consciência e promover estilos de vida saudável, autoestima positiva, não violência e também para promover os direitos das crianças ${ }^{11}$.

A Organização das Nações Unidas $(\mathrm{ONU})^{11}$ também admite, a respeito dos impactos das práticas de publicidade sobre os direitos culturais e sobre a saúde, que a informação não é suficiente para provocar mudança de comportamento, no que se refere à obrigatoriedade - estabelecida em alguns países e também proposta no âmbito da RDC n² 24 de 2010 - de veiculação de mensagens de alerta durante os comerciais de alimentos nocivos à saúde. São necessárias medidas adicionais de proteção.

Nesse sentido, é possível que a autorregulamentação seja insuficiente, por ser realizada por pares - o Conar é composto por representantes dos próprios anunciantes - e por saber-se que as crianças e adolescentes não possuem discernimento suficiente e adequado para compreender as estratégias publicitárias como tal ${ }^{2,3}$. A Frente pela Regulação da Publicidade 
de alimentos ${ }^{34}$, que congrega entidades da sociedade civil nos âmbitos acadêmico, científico e de defesa de Direitos, aponta que a atuação do Conar não vem apresentando resultados efetivos no tema da publicidade infantil, demonstrando-se também contrária à chamada corregulação, que seria o compartilhamento da regulação entre o Estado e o setor regulado, com fiscalização da autorregulamentação.

O Estado Brasileiro não possui estratégia vigente de regulação da publicidade de alimentos voltada para crianças e adolescentes. No campo da regulação de publicidade de produtos, bens e serviços que impactam a saúde, a Anvisa possui reconhecida atuação na regulação da publicidade de medicamentos, tabaco e bebidas alcoólicas, atuação essa historicamente permeada por conflitos de interesse por parte do setor regulado.

Apesar da ausência de estratégia na área, dando reforço às ações regulatórias sobre alimentos, o Governo Federal publicou recentemente o Decreto $\mathrm{n}^{0}$ 8.552, de 03 de novembro de $2015^{35}$, regulamentando a Lei $n^{0} 11.265$, de 3 de janeiro de $2006^{36}$, que dispõe sobre a comercialização e a publicidade de alimentos para lactentes e crianças de primeira infância e de produtos de puericultura correlatos. A Lei ficou conhecida como Norma Brasileira de Comercialização de Alimentos para Lactentes e Crianças de primeira infância, Bicos, Chupetas e Mamadeiras (NBCAL), e por um período de quase nove anos, permaneceu sem regulamentação. No escopo do Decreto em questão, o Governo Federal regulamenta a publicidade de alimentos que influenciam negativamente o aleitamento materno e as práticas de alimentação complementar saudável. A Lei em referência e o Decreto, por conseguinte, podem vir a representar importante passo do Estado Brasileiro no tocante à regulamentação da publicidade de alimentos. 


\subsection{VULNERABILIDADE, AUTONOMIA E ESCOLHAS ALIMENTARES}

Realizar escolhas alimentares adequadas pressupõe autonomia. Para além da disponibilidade de informações corretas e completas, sabe-se que há diversos fatores que influenciam e determinam as escolhas dos alimentos como acesso físico e financeiro, a cultura alimentar, os gostos e preferências individuais - e a publicidade inclui-se entre $\mathrm{eles}^{28}$. Ficará demonstrado que autonomia pressupõe informação e ausência de influências indevidas, e também que o processo de construção da autonomia requer redução das vulnerabilidades, o que, no caso de crianças e adolescentes, trata-se de vulnerabilidade intrínseca à fase da vida, ou seja, a inabilidade em escolher seus próprios alimentos de maneira adequada está condicionada à idade e, adicionalmente, trata-se de vulnerabilidade provocada pela influência indevida da publicidade.

Neste trabalho, a questão da autonomia é tratada a partir de uma visão não individualista, mas considerando que o processo de desenvolvimento da autonomia para as escolhas alimentares é coletivamente influenciado e determinado, pela família, ambiente escolar, mídia e pelo modo de vida da sociedade como um todo, que nos oferta modelos e impõe padrões alimentares. A habilidade para escolhas saudáveis é um processo em desenvolvimento, especialmente durante o período da infância.

Acerca do compromisso com a redução da vulnerabilidade, a Declaração Universal sobre Bioética e Direitos Humanos (DUBDH) da Organização das Nações Unidas para a Educação, a Ciência e a Cultura (Unesco), aclamada por todos os países membros desta entidade em 2005, traz, em seu artigo oitavo, que:

A vulnerabilidade humana deve ser levada em consideração na aplicação e no avanço do conhecimento científico das práticas médicas e de tecnologias associadas. Indivíduos e grupos de vulnerabilidade específica devem ser protegidos e a integridade individual de cada um deve ser respeitada (Unesco, 2005, p. 6) ${ }^{37}$. 
Partindo-se do Relatório do Comitê Internacional de Bioética da Unesco sobre Vulnerabilidade e Integridade Pessoal ${ }^{38}$, um dos documentos que oferecem suporte à compreensão dos princípios contidos na DUBDH, entendese vulnerabilidade como as condições que, mais ou menos diretamente, influenciam na nossa capacidade de viver como indivíduos livres e autônomos.

O Relatório trabalha com a visão de Vigilância no sentido de proteção do bem estar de indivíduos e grupos vulneráveis, compreendidas entre tais grupos as crianças, por seu estágio de vida que implica reduzida capacidade de escolhas autônomas - na situação ora em análise, prejudicadas, ainda, pela influência da publicidade. Esse entendimento reforça a importância de se valorizar uma ampla gama de princípios como autonomia, beneficência, justiça, dignidade e equidade, entre outros. O princípio da vulnerabilidade e integridade pessoal não apenas enfatiza tais metas, mas também torna visível que o objetivo último do progresso da ciência, no âmbito da bioética, não pode ser o lucro $^{38}$.

Para além do cumprimento das normativas vigentes e das obrigações fundamentais que temos uns para com os outros, a importância do entendimento do princípio da vulnerabilidade e integridade pessoal contido na DUBDH com relação ao debate em questão, convoca gestores, acadêmicos e profissionais de saúde e nutrição - corresponsáveis pelo avanço do conhecimento na área e pelas decisões de como utilizá-lo - a reconhecer a realidade da vulnerabilidade ${ }^{38}$, buscando construir uma ponte entre as diferentes visões sobre a regulação da publicidade de alimentos em uma sociedade pluralista, de modo a valorizar mais a solidariedade do que meros interesses individuais.

Reconhecer, respeitar e reduzir a vulnerabilidade de crianças e adolescentes diante da publicidade de alimentos significa, portanto, protegê-los de tal exposição e buscar, por outro lado, fornecer elementos para apoiar a construção de sua autonomia nas escolhas alimentares. 
Nesse sentido, a definição de Beauchamp e Childress ${ }^{39}$ para o conceito de autonomia pessoal engloba o autogoverno livre de interferência e controle externo e de limitações que atrapalhem a realização de escolhas significativas. Um exemplo de prejuízo à realização de escolhas seria o entendimento inadequado; a ação autônoma deve ter intenção, compreensão da situação e ausência de influências que controlem ou determinem tal ação. Nesse sentido, fica claro que as crianças e adolescentes não possuem plena compreensão da situação - quais os objetivos da publicidade e quais os meios utilizados para tal - e, assim, são indevidamente influenciadas em suas escolhas.

Tal raciocínio poderia ser usado também no debate sobre a limitação à autonomia para fazer escolhas alimentares até mesmo em se tratando de pessoas adultas. As diversas teorias sobre a autonomia estão condicionadas à liberdade, enquanto independência de controle externo, e à capacidade de agência, de ação intencional. Algumas teorias tratam das habilidades necessárias ao autogoverno como: compreensão, raciocínio, administração, deliberação, e escolhas independentes. Beauchamp e Childress ${ }^{39}$ focam sua análise sobre autonomia na qualidade das escolhas autônomas, mais do que na capacidade de autogoverno.

$\mathrm{Na}$ visão de Engelhardt ${ }^{40}$, o respeito à autonomia deve promover uma ação sem coação externa, onde estejam presentes categorias como o respeito à pessoa e o consentimento. Como dito, pessoas em situação de vulnerabilidade - como crianças e adolescentes - devem ser protegidas.

No que tange às escolhas alimentares, respeitar agentes autônomos é reconhecer o seu direito a fazer escolhas e a agir com base em seus valores, costumes e crenças. É a obrigação de respeitar a capacidade das pessoas autônomas em tomar decisões, de posse de informações corretas e completas sobre uma alimentação adequada e saudável, e implica condição anterior, socioeconômica, para adquirir os alimentos.

O respeito à autonomia envolve, assim, agir respeitosamente, não apenas ter uma atitude de respeito. As propostas de autorregulamentação, 
nesse sentido, seriam uma suposta atitude de respeito por parte dos anunciantes; no entanto, induzir crianças e adolescentes a escolhas, na maioria das vezes, não saudáveis, não pode ser avaliada como uma ação respeitosa.

De acordo com Beauchamp e Childress ${ }^{39}$, respeitar a autonomia requer mais do que não interferência; inclui, em alguns contextos, construir ou manter a capacidade das pessoas para escolhas autônomas, e essa atitude diz respeito também ao princípio kantiano de tratar as pessoas como fins, assistindo-as para o alcance de seus objetivos e forjando sua capacidade como agentes, não as tratando como meios para alcançar os fins. No caso da publicidade de alimentos, a finalidade, conforme definição apresentada, é a formação de mercado e fidelização de consumidores para aumento das vendas, portanto, visando o lucro.

Isso posto, em situações em que se encontram pessoas com autonomia frágil, é necessário trabalhar a ampliação de capacidades dessas pessoas para que sua autonomia possa se desenvolver e seja reforçada. Se fôssemos considerar resolvida a questão básica do acesso físico e financeiro aos alimentos, na situação ora em debate, crianças e adolescentes deveriam ter, ainda, acesso a informações sobre alimentação adequada e saudável por meio de ações de educação alimentar e nutricional, partindo-se de perspectivas de empoderamento, por meio de práticas problematizadoras, visando à construção de melhores condições para que se possa desenvolver a prática de escolhas autônomas ${ }^{41}$.

\subsection{A RESPONSABILIDADE DO ESTADO NA REGULAÇÃO}

Tendo reconhecido que crianças e adolescentes são vulneráveis à exposição à publicidade de alimentos, requerendo medidas de proteção e fortalecimento de sua autonomia, passemos a explorar questão da 
responsabilidade do Estado diante de tais compromissos. Como balizadores da temática, apropriamo-nos de bases da Bioética de Intervenção, que teve suas proposições iniciais elaboradas por Garrafa e Porto, além do pensamento de Hans Jonas e seu Princípio Responsabilidade.

As lacunas da Bioética principialista de Beauchamp e Childress, de cunho hegemônico, colocaram a necessidade de aprofundar conhecimentos em proposições que se mostrassem capazes de oferecer enfrentamento ao discurso e à prática dominantes, insuficientes para compreensão e problematização das realidades dos países latino-americanos. Buscando amplitude em seus referenciais e conceitos para além da lógica principialista, a Bioética de Intervenção ${ }^{42}$ apresenta fundamentos assentados em interpretações e ações "multi-inter-transdisciplinares" que perpassam diversas áreas do conhecimento humano. Contribuem às denominadas bioéticas de abordagem crítica os conhecimentos produzidos pela filosofia, pelo direito e pelas ciências humanas.

Buscando estabelecer diálogo com a lógica de pensamento da Bioética de Intervenção no que toca à problematização das realidades latinoamericanas, Nascimento e Garrafa ${ }^{43}$ apontam que os estudos sobre colonialidade, aqui colocados de maneira bastante pontual e resumida, compartilham da visão de que deve existir uma forma de pensar - e talvez, um modo de andar a vida - que parta das perspectivas dos subjugados, explorados, colonizados que somos os povos latino-americanos. Essa lógica atravessa o debate da regulação de publicidade no que se refere aos conceitos e aos interesses por detrás dos conceitos estabelecidos, quando utilizamos termos como publicidade, ética, autonomia, informação, e, assim, nos discursos que construímos como realidade de mundo.

Para Nascimento e Garrafa $^{43}$, a ideia de estreitar o diálogo entre a Bioética de Intervenção e os estudos da colonialidade é "desmistificar a imagem colonizada de vida" (Nascimento e Garrafa, 2011, p. 293), atentando para o fato de que os discursos hegemônicos, baseados na colonialidade, apresentam-se como generosos, o que requer da Bioética uma abordagem 
crítica e comprometida com a realidade dos países do hemisfério Sul, oprimidos, colonizados. Para tanto, é possível, de acordo com os autores, estabelecer diálogos com esses discursos, inclusive apropriando-se de ferramentas teóricas do Norte, tendo em conta, no entanto, que a visão hegemônica advinda dessa linha de pensamento esconde as armadilhas coloniais.

Ainda, no âmbito conceitual da Bioética de Intervenção, a ação social deve ter envolvimento político e comprometimento com as situações de vulnerabilidade, com proposições contextualizadas e capacidade de transformação das realidades sociais. Tal entendimento contextualizado e comprometido com o lado mais frágil da sociedade tornou patente a opção por essa linha de pensamento para iniciar a compreensão da regulamentação da publicidade como responsabilidade do Estado.

A Bioética de Intervenção partilha do conceito epidemiológico da determinação social do processo saúde e adoecimento, percebendo que a vulnerabilidade configura-se como limitação à autonomia, portanto, à plena realização do potencial de saúde. Crianças e adolescentes, nessa visão, encontram-se em situação de vulnerabilidade e, portanto, incapacidade de proteger os próprios interesses. Assim, a adequada abordagem para esses indivíduos deve prever limites diminuídos de risco aceitável e necessidade de ampliação das medidas de proteção (no caso, o risco da exposição à publicidade de alimentos e a proteção por meio de controle estatal). Essa abordagem também está presente no texto da $\mathrm{DUBDH}^{37}$ em seu artigo quarto, que trata de benefício e dano.

Com relação à fundamentação filosófica, a Bioética de Intervenção ${ }^{44}$ trabalha com uma base utilitarista e consequencialista, defendendo propostas que atendam ao maior número de pessoas, pelo tempo mais longo possível e que tenham como resultado as melhores consequências para a coletividade, ainda que gerem restrições individuais. Esse é o caso das ações regulatórias implementadas pelo Estado; têm a difícil missão de enfrentar poderosos interesses econômicos com a intenção de proteger os interesses da maioria, 
com a finalidade última, na análise que diz respeito à regulação da publicidade, de garantir a saúde e a alimentação adequada, direitos previstos constitucionalmente.

A valorização da perspectiva coletiva sobrepondo interesses individuais pressupõe aplicar também o princípio da justiça na análise da questão da regulação de publicidade de alimentos, contexto para o qual a Bioética de Intervenção traz reforço na interpretação histórico-social.

Por meio do instrumental da Bioética de Intervenção, ainda conforme verbete de Garrafa $^{44}$ para o Diccionario Latino-americano de Bioética, é possível sustentar a relevância de transformações concretas e permanentes em vez de mudanças superficiais, e a negação de uma postura de neutralidade, optando pela politização de situações onde se estabeleçam conflitos.

Assim, para além dos quatro princípios tradicionais, a Bioética de Intervenção ${ }^{42}$ propõe-se a utilizar os denominados Quatro "Pês" para o exercício de uma prática da bioética que se defina comprometida com as questões de vulnerabilidade, com o ambiente em que vivemos e com o trato adequado aos interesses públicos. Os "Pês" são: prevenção, proteção, prudência e precaução. Prevenção contra possíveis danos, proteção aos segmentos mais vulneráveis da sociedade, prudência com relação aos avanços da tecnociência e precaução frente ao que desconhecemos.

Os referenciais teóricos e práticos de proteção e prevenção colocam-se como guias utilizados para evitar possíveis danos e iatrogenias advindos do uso de tecnologias e serviços de interesse para a saúde pública, onde podemos incluir a publicidade de alimentos, uma vez que a população, especialmente as crianças e os adolescentes, estão vulneráveis e suscetíveis, ao mesmo tempo, aos possíveis riscos associados à sua exposição, prejudicando e limitando o desenvolvimento de sua autonomia nas escolhas.

Para Hans Jonas $^{20}$, a autonomia dos sujeitos está ameaçada devido à massificação que os impede de decidir e responsabilizar-se. Ainda, de acordo 
com o autor, é preciso buscar um novo patamar ético para o progresso técnico global e o uso adequado das tecnologias, patamar esse fundado pela responsabilidade. A ação humana deve ser orientada de maneira a garantir a permanência da vida na Terra, devendo a ética aplicar-se ao agir individual e ao público, considerando o imperativo de que deve haver um futuro.

Interpretando essa visão da Ética da Responsabilidade, defendida por Jonas, entende-se que as empresas fabricantes de produtos e ofertantes de serviços que interferem direta ou indiretamente na saúde devem garantir a qualidade dos produtos e serviços, agindo de forma responsável em benefício da população que, muitas vezes, precisa ser protegida por meio de intervenções do Estado, justamente em vista de sua vulnerabilidade. A Ética da Responsabilidade consiste, então, em um agir que se antecipa à ação e não como cobrança ou imputação de um ato já acontecido ${ }^{20}$.

No mesmo sentido, a Bioética de Intervenção atribui ao Estado a responsabilidade de garantir os direitos da população, reforçando eticamente a necessidade de intervenção do Estado em questões como a regulação de publicidade de alimentos ${ }^{2}$.

Ainda, para a Bioética de Intervenção, a responsabilidade do Estado serve também para garantir e preservar a dignidade das pessoas, individualmente e enquanto grupos sociais, de maneira a contribuir para minimizar as assimetrias nas relações sociais e amenizar os efeitos das diversas vulnerabilidades, em uma lógica concebida como equitativa ${ }^{2}$. 


\section{OBJETIVOS}

\subsection{OBJETIVO GERAL}

Analisar a perspectiva ética presente no discurso contrário à regulação da publicidade de alimentos direcionada a crianças e adolescentes.

\subsection{OBJETIVOS ESPECÍFICOS}

- Conhecer os argumentos presentes no discurso contrário à regulação da publicidade de alimentos direcionada a crianças e adolescentes;

- Descrever o contexto de produção do discurso em referência;

- Conhecer efeitos do discurso;

- Verificar o alinhamento ou não do discurso aos princípios bioéticos de proteção aos vulneráveis e de responsabilidade;

- Identificar se a proposta de autorregulamentação converge para a promoção da autonomia para escolhas alimentares. 


\section{METODOLOGIA}

Essa dissertação trabalhou com metodologia qualitativa, sendo um estudo exploratório, documental, utilizando-se de conceitos, ferramentas e procedimentos da Análise de Discurso (AD) para conhecer o discurso contrário à regulação, por parte do Estado, da publicidade de alimentos direcionada a crianças e adolescentes.

O discurso foi extraído de um documento selecionado para estudo, consistindo o trabalho em várias leituras sucessivas do texto, tendo-se realizado análise dos argumentos presentes no discurso, buscando reconhecer o contexto em que se estabelecem e compreender como produzem sentidos, especialmente no que tange à perspectiva ética.

Utilizaram-se, então, os resultados obtidos da análise para discutir acerca das propostas de autorregulamentação e regulação da atividade em questão por parte do Estado.

A proposta da Análise de Discurso foi-se construindo em conjunto com a discussão, porque ao longo do estudo do método percebeu-se que a análise não poderia ser efetuada de maneira dissociada da discussão. Destaque-se que, conforme será demonstrado, a análise de discurso como prática metodológica não permite postura neutra ou descolada de visão ideológica do analista. A todo momento, a visão de quem analisa está intimamente implicada com o material de estudo, desde o momento de escolha desse material, portanto, a análise e a discussão dos sentidos que ela traz são indissociáveis dentro do método.

As lentes que pautaram a análise e a discussão foram a ética da responsabilidade e a bioética de intervenção. 


\subsection{UNIVERSO DE ESTUDO}

O estudo foi realizado no âmbito do cenário nacional de discussão sobre a regulação pelo Estado da publicidade de alimentos direcionada a crianças e adolescentes, que envolve órgãos de governo, movimentos sociais afetos ao tema e instituições representantes de setores da indústria de alimentos e de publicidade. Mais especificamente, o discurso em análise foi obtido por meio de documento produzido pelo Conar, conforme detalhado a seguir.

\subsection{PROCEDIMENTOS}

A primeira etapa da pesquisa consistiu da escolha de um documento que expressasse o discurso contrário à regulação, por parte do Estado, da publicidade de alimentos direcionada a crianças e adolescentes.

O documento selecionado para análise foi um manifesto elaborado e divulgado pelo Conar em agosto de 2012 em seu site, que expressa contrariedade às propostas de regulação da publicidade (de maneira geral, não somente publicidade de alimentos) voltada a crianças e adolescentes, intitulado "Cidadãos responsáveis e consumidores conscientes dependem de informação (e não da falta dela) - As normas éticas e a ação do Conar na publicidade de produtos e serviços destinados a crianças e adolescentes". Cópia do documento encontra-se anexa (ANEXO).

Complementarmente, realizou-se pesquisa no site do Conar sobre a composição do Conselho de Ética da entidade.

Uma vez selecionado o documento descrito, que compôs, assim, o corpus de análise, durante a segunda etapa foi realizada a análise do discurso presente no documento, utilizando o método de Análise de Discurso - conforme referencial proposto originalmente por Michel Pêcheux e apresentado por Eni Orlandi $^{45}$ - buscando revelar a forma como a linguagem se materializa na 
ideologia e como essa se manifesta na linguagem. Para a Análise de Discurso, importa compreender os sentidos assumidos pelos discursos, não somente na forma linguística mas também material da ideologia, considerando o sujeito, sua história, o contexto social em que se insere.

Segundo Orlandi ${ }^{45}$, a prática de leitura de Pêcheux, que constitui a Análise de Discurso, procura expor o leitor à opacidade - materialidade - do texto, com o objetivo de levar à compreensão do que o sujeito diz em relação a outros dizeres. O texto exemplifica o discurso e permite que se tenha acesso a ele, não sendo o texto, objeto final de interesse; o produto da análise será uma compreensão de como o texto produz sentidos e como se constituem os sujeitos que os produzem, da sua posição enunciativa.

A orientação metodológica da autora escolhida apontou para a elaboração de um dispositivo de interpretação, conformando um conjunto de definições, conceitos e perguntas que serviu de apoio para a identificação dos sujeitos que se manifestam por meio do discurso. Qual sua filiação de sentidos? Que noção de ética permeia as construções do discurso desses sujeitos? Qual sua relação com determinadas memórias e ideologias? O dispositivo mistura descrição e interpretação, e o sujeito que fala, também faz movimentos de interpretação, segundo Orlandi ${ }^{45}$. Coube aqui uma relativização da posição do analista em face da interpretação, procurando perceber como o discurso funciona e como produz seus sentidos - com quais princípios éticos o discurso está comprometido, quais as condições de produção.

Em complemento à análise de discurso, trabalhou-se com algumas das ferramentas da abordagem lógico-afirmativa para avaliação de argumentos, indicadas no âmbito do Método em Seis Passos, proposto por Julio Cabrera ${ }^{46}$. O método constitui-se em um esquema geral com passos para avaliar a validade das premissas, inferências e conclusões presentes nos argumentos. Os passos verificam a existência real do argumento; existência do argumentador; reconstrução do argumento; clareza dos termos e valor de verdade das premissas; correção do argumento e; propósito do argumento. Para a abordagem afirmativa, o uso de um procedimento como o Método em 
seis passos seria capaz de decidir se os argumentos estariam corretos ou não. No presente trabalho, buscou-se apoio do Método em seis passos com a finalidade de verificar como se apresentam os argumentos no âmbito do discurso e como tais argumentos apoiam ou não a construção da perspectiva ética do Conar.

Conforme foram sendo revelados os sentidos buscados por meio da análise, foi-se intercruzando o discurso com as referências da Ética de Responsabilidade proposta por Hans Jonas e do cabedal da Bioética de Intervenção - cujos referenciais iniciais foram propostos por Garrafa e Porto e que seguem crescendo como perspectiva não hegemônica no âmbito dos estudos das Bioéticas de abordagem crítica - refletindo sobre a autorregulamentação e sobre a regulação, por parte do Estado Brasileiro, da publicidade de alimentos direcionada a crianças e adolescentes.

\subsection{ASPECTOS ÉTICOS DA PESQUISA}

Por não envolver pesquisa com seres humanos, não foi necessário realizar submissão do trabalho ao Comitê de Ética da Faculdade de Saúde da Universidade de Brasília. 


\section{RESULTADOS E DISCUSSÃO}

Para Eni Orlandi, "[...] a relação com a linguagem não é jamais inocente, não é uma relação com as evidências [...]" (Orlandi, 2001, p. 95) ${ }^{45}$. Importante estabelecer que o texto é a unidade da qual se parte para remeter a um discurso, que transparece por meio do texto e não se dá como algo posto, mas ganha sentido como algo que deriva da formação ideológica de cada conjuntura. A definição do material de análise, do corpus, acontece como construção de quem o analisa ${ }^{45}$. Assim, o primeiro movimento de análise de discurso está colocado, por meio da escolha do documento e dos trechos desse documento que compõem o corpus.

Nas seções que seguem, procurou-se analisar os argumentos apresentados no documento, o contexto em que o discurso foi produzido e o modo como produz sentidos, a perspectiva ética que foi possível extrair do texto, dialogando com os princípios e, portanto, com os discursos da Bioética de Intervenção e da Ética de Responsabilidade.

O documento foi analisado em profundidade, porém, não exaustivamente em sua extensão, entendendo que os discursos contidos no documento são inesgotáveis, tomados em sua incompletude, conforme entende-se da metodologia da Análise de Discurso.

\subsection{O DISCURSO DO CONSUMO CONSCIENTE E INFORMADO}

O documento "Cidadãos responsáveis e consumidores conscientes dependem de informação (e não da falta dela) - As normas éticas e a ação do Conar na publicidade de produtos e serviços destinados a crianças e adolescentes" ${ }^{33}$ expõe as normas éticas e trata sobre a atuação do Conar em contraposição às propostas de regulação pelo Estado da publicidade 
direcionada a crianças e adolescentes. Refere-se à publicidade de todo tipo de produto e serviço destinado a crianças e adolescentes, incluindo, portanto, a publicidade de alimentos voltada a esse público. Destaque à publicidade de alimentos foi abordado mais especificamente na seção quatro do documento.

Somente em sua segunda parte o título do documento permite identificar do que se trata, trazendo a parte inicial uma frase afirmativa que apresenta opinião dos sujeitos que o produziram. Essa afirmação contesta outro discurso, contrário ao apresentado no documento em questão, por meio da negação desse outro discurso, tido pelo Conar como desfavorável à disponibilização de informação como meio para alcance da cidadania, responsabilidade e consciência no consumo.

Uma primeira leitura do documento do Conar permite perceber que está organizado em sete seções - quatro delas nominadas por afirmações, a saber: 1- O Conar reflete de forma democrática, ética e técnica os anseios da sociedade em questões que envolvam o consumo e a publicidade; 2- A publicidade brasileira é uma atividade que traz a ética em seu DNA; 3- O sistema misto de legislação e autorregulamentação provê a segurança que convém ao consumidor; 4- A solução para a epidemia de obesidade infantil passa pela família, educação - e também pela autorregulamentação; 5- Uma breve história do Conar; 6- A íntegra da Seção 11 do Código Ético-Publicitário; e 7- As campanhas processadas.

No que concerne ao conteúdo, as seções apresentam uma descrição histórica acerca da temática de autorregulamentação publicitária, seguida pela exposição de dados a respeito da atuação do Conar, apontando a publicidade brasileira como "[...] ética de nascença" (Conar, 2012, p. 2) ${ }^{33}$ e o Conar como disposto a "refletir [...] os anseios da sociedade" (Conar, 2012, p. 3$)^{33}$.

Explorando o documento em suas seções, percebe-se que os esquemas discursivos estão presentes nas primeiras cinco seções, trazendo as duas últimas trechos descritivos sobre o Código de autorregulamentação e expositivos sobre as ações autorregulatórias empreendidas pelo Conar até o momento da publicação do documento em questão. 
Como percepção inicial a ser explicitada, a utilização de argumentos visuais está bastante presente no documento do Conar; na capa, optou-se pela fotografia de uma menina sentada de costas em um balanço, funcionando como parte do discurso estético em favor do conteúdo do texto.

A posição da menina - de costas para o leitor do texto - parece torná-la especialmente desprotegida contra ataques (colocando o próprio observador na posição de atacante/ameaçador); mas, por outro lado, o fato de não se mostrar o rosto da menina faz com que a expressão facial não desempenhe nenhum papel na argumentação visual. Também pode transparecer a ideia de que regular a propaganda (ou suprimir informação, conforme sugere a linguagem utilizada pelo Conar no título do documento) seria como dar as costas à criança, ou ignorar uma necessidade sua - no caso, a necessidade de informação por meio da propaganda. Mostra-se, então, o impacto que o Conar quer evitar, já na capa, mas também a que serve o discurso ali contido, contra o quê e quem ele se coloca.

As demais fotos apresentadas ao longo do documento, com os rostos de crianças e de uma adolescente felizes e serenas, em situações de brincadeiras, aparecem em seções onde são apresentados dados sobre a atuação do Conar, supostamente demonstrando contentamento pela atitude de proteção a essas crianças oferecidas pelo Conselho.

Optou-se por separar alguns pontos de análise por seção, e eventualmente, comentários analíticos são tecidos envolvendo tópicos referentes a outras seções. Algumas das seções foram analisadas em maior extensão, de acordo com a identificação de pontos relevantes para o estudo dos fundamentos éticos presentes no discurso, a filiação ideológica que sustenta o discurso e a maneira como ele produz seus efeitos. 


\subsubsection{Primeira Seção - O Conar reflete de forma democrática, ética e técnica os anseios da sociedade em questões que envolvam o consumo e a publicidade}

Na primeira seção, são apresentadas as justificativas iniciais do Conar para defender seu trabalho como válido e suficiente em termos de autorregulamentação da publicidade direcionada a crianças e adolescentes no Brasil. O Conselho apresenta-se como pioneiro na imposição de restrições a anúncios voltados a crianças e adolescentes, destacando que a sua é anterior à preocupação de autoridades e sociedade e até mesmo anterior à promulgação do Estatuto da Criança e do Adolescente (ECA).

Adiante, ver-se-á que o contexto onde brotou esse pioneirismo não envolve genuína preocupação com a proteção do público infantil, portanto, não se alinha aos objetivos do ECA, das autoridades ou da sociedade em suas diversas representações.

Crianças e adolescentes são tratados como "[...] menores de idade" (Conar, 2012, p. 2) ${ }^{33}$; de acordo com o Glossário de termos da ANDI Comunicação e Direitos - Agência de Notícias dos Direitos da Infância ${ }^{47}$, o termo "menor" é considerado inapropriado, desde a entrada em vigor do ECA, por apresentar sentido pejorativo. Assim, entende-se que não deveria ser utilizado para designar ou caracterizar crianças e adolescentes, que são legalmente sujeitos de direitos. O glossário aponta, ainda, que o termo contribui para a reprodução de discriminação, estigma e exclusão social, pois remete ao extinto Código de Menores. Em vários outros pontos do documento, crianças e adolescentes são referidos pelo discurso como menores ou menores de idade, e até "[...] menores infratores" (Conar, 2012, p. 4) ${ }^{33}$.

Fornecendo informações sobre o Código de Autorregulamentação Publicitária, o texto aponta que foi revisado completamente em 2006, como reflexo da preocupação da sociedade com o tema, sem explicar como foi construída, ou como surgiu essa preocupação por parte da sociedade. 
No ano de 2006, a ANVISA iniciou o processo de consulta pública ao texto prévio da RDC que propunha a regulamentação estatal de publicidade e outros tipos de promoção comercial de alimentos. Associa-se, então, o movimento realizado pelo Conar como responsivo à pressão pela regulação de sua atividade comercial, embora descrito como reflexo da preocupação da sociedade com o tema.

Utilizando o método em seis passos para avaliação de $\operatorname{argumentos}^{46}$, é possível detectar, no documento, a presença de um tom muito descritivo, tecendo afirmações e abordando a existência de regulamentos e dispositivos legais que constituem, antes, comandos a respeito da ordem pública do que genuínos argumentos.

A exposição de dados estatísticos a respeito dos processos éticos instaurados pelo Conar - que pareceria ser meramente descritiva - pode estar sendo trazida para o discurso como premissa argumentativa; por outro lado, às vezes usam-se palavras argumentativas, como por exemplo, "Afinal [...]", "Pelo contrário [...]", "[...] muito menos [...]" (Conar, 2012, p. 2) ${ }^{33}$, sem haver realmente argumentos, do ponto de vista do método em seis passos para análise de argumentos. É possível, assim, chegar-se ao entendimento de que não são apresentados quaisquer argumentos, apenas tentativas de imposição de um ponto de vista.

Para além da descrição, informação e afirmação presentes no texto como regra, alguns argumentos são de fato apresentados, conclusões são defendidas por meio desses argumentos, expondo dados numéricos - que parecem ter sido utilizados como justificativas de apoio aos argumentos. $O$ quantitativo de denúncias registradas e processos instaurados pelo Conar em determinado período é assim julgado:

$[\ldots]$ [... 2) 3 .

A negação de que o número de denúncias seria alto pressupõe que haja uma opinião em contrário, que não é relevada no texto. 
Esse julgamento de que o quantitativo de denúncias recebidas não era alto foi utilizado para apoiar a retórica que se segue:

[...] diante desses números emerge intocado o fato de que a publicidade brasileira é ética de nascença, sendo o respeito ao

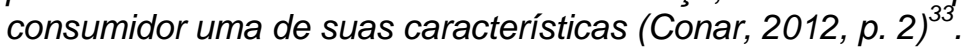

$\mathrm{Na}$ interpretação do Conar, os números são suficientes e soberanos para apoiar a condição ética basilar da publicidade brasileira. Por meio dessa opção pelos números para determinar a condição de ser ou não ser ética a publicidade, identifica-se o estabelecimento de relações de poder sobre o interlocutor, em uma tentativa de convencimento que não permite questionamento, porquanto intocável. Patrick Dahlet $^{48}$ aponta a incontestabilidade e a construção de "[...] verdades óbvias fundantes do bom sentido comum [...]", muito utilizadas como operações enunciativas na narrativa do discurso neoliberal (Dahlet, 2015, p. 220).

A premissa que define o fato como intocável não pode ser aceita, pois poderia haver diversos motivos para o baixo número de representações julgadas, entre eles: pouca capacidade de denúncia pela sociedade, pouco alcance das medidas regulatórias do Conar, pouco interesse em fazer tais julgamentos, regras de autorregulação tão frouxas que permitiriam um baixo potencial de enquadramento das peças publicitárias como passíveis de julgamento.

Possivelmente, o perfil ético da publicidade tenha sido questionado, o que levou o Conar a munir-se das armas que possui para defender-se, quais sejam, os números, utilizados em seu favor. Transparece uma tentativa de mensurar princípios éticos matematicamente, sem discutir tais princípios. A característica ética da publicidade brasileira é um discurso trazido pronto, calculado, fechado, intocado, naturalizado e não aberto a diálogo. Poder-se-ia questionar ao discurso, caso os números mudem, se mudaria também a característica ética de nascença afirmada.

Garrafa $^{49}$ afirma, em verbete sobre Ética e Política para o Diccionario Latino-americano de Bioética, que a ética utilizada como conceito asséptico 
está a serviço de perspectivas neutrais de interpretação das realidades permeadas por conflitos sociais, que, somada à despolitização de conflitos morais, contribui para ampliar as contradições e aprofundar as desigualdades sociais. Assim, pontuar o tema da inclusão social na agenda de discussões éticas seria fundamental para reaproximar ética e política.

No verbete do mesmo dicionário que aborda globalização e o mercado da alimentação, Jorge Eduardo Rulli50 aponta que o discurso de ética e responsabilidade social utilizado no meio empresarial transformou-se em um modo eficaz para agregar valor a produtos e serviços e propor novas formas de maximizar os lucros; a identificação de corporações ao discurso ético tornouse, portanto, rentável.

Avaliando-se a clareza dos termos e o valor da verdade das premissas do trecho em análise, identificou-se a presença de termos-chave da questão (ex: consumidor, ética, informação, abusiva, respeito ao consumidor), como premissas assumidas e não discutidas. Alguns termos correm o risco de ser apresentados de maneira puramente retórica, especialmente quando envolvem a palavra ética (a exemplo das expressões DNA ético, ética de nascença).

Nenhum dos termos fundamentais para 0 entendimento da argumentação foi definido, tampouco se discutiu premissas como publicidade ética de nascença, respeito ao consumidor, liberdade de expressão comercial, que serviram de base dos argumentos, prejudicando, assim, a aceitação dessas premissas como verdadeiras e, por fim, o rendimento dos argumentos presentes no discurso. Assim, de acordo com o Método em Seis Passos ${ }^{46}$, os argumentos utilizados no discurso poderiam vir a ser considerados incompletos e equivocados.

É justamente essa incompletude do discurso que permite diferentes significações por parte dos diferentes interlocutores. De onde fala o Conar, crianças e adolescentes são vistos como menores e como consumidores, não como vulneráveis; são tratados, para além da visão discriminatória, como objetos e não fins em si mesmos. A ética da publicidade não é uma ética de proteção, não assume responsabilidade sobre as escolhas desses vulneráveis. 
A informação a que defendem o acesso não é informação sobre os danos que a exposição à publicidade pode causar às crianças e adolescentes. Tampouco os danos à saúde causados pela má alimentação, grandemente influenciada pelas peças publicitárias que os associados do Conar produzem e veiculam, e que são eventualmente julgadas eticamente pelos próprios pares, como será demonstrado adiante.

A primeira seção é finalizada com a argumentação de que os processos éticos julgados pelo Conar servem para:

\begin{abstract}
[...] historiar a ação da autorregulamentação publicitária a serviço da sociedade, expressa a disposição permanente do Conar em refletir da melhor maneira possível, com espírito verdadeiramente democrático, os anseios da sociedade nessa e em outras questões que envolvam o consumo e a publicidade. Expressa também a nossa disposição de defender a liberdade de expressão comercial e a relevância socioeconômica da publicidade para a sociedade contemporânea, porque o Conar acredita que cidadãos responsáveis e consumidores conscientes dependem da informação e que a falta dela prejudicaIhes a autonomia e a liberdade de escolha (Conar, 2012, p. 3) ${ }^{33}$.
\end{abstract}

Aqui, ocorre a manipulação da noção de democracia, como saber compartilhado, buscando aliança com esse saber, colocando-o em lugar incontestável, tratando de questão cara e sensível para a sociedade, entre outras, como a relevância da publicidade do ponto de vista socioeconômico.

Primeiramente, essa designação implica que a atividade é relevante do ponto de vista social e econômico, como injunção, entre outras: falar da autorregulamentação publicitária a serviço da sociedade implica que se concorde, previamente, que a autorregulamentação publicitária está a serviço da sociedade; do mesmo modo, que a sociedade anseia por essa e outras questões que envolvam consumo e publicidade; que deve haver liberdade para a expressão comercial. Novamente, trata-se de reprodução do inquestionável, uma forma oculta de enunciação que coloca os termos fora de qualquer possibilidade de argumentação, conforme Dahlet ${ }^{48}$.

Por outro lado, e paradoxalmente, como que contestando o Estado Democrático de Direito, está em jogo para o Conar o funcionamento da sociedade como um todo, as bases democráticas do Estado, seu modo de 
atuar e seu papel. O que é mostrado como democrático, em verdade, é o espírito do Conar ao refletir os anseios da sociedade.

O Conar não define o que seria essa verdadeira democracia, pois, como nos mostra Adela Cortina ${ }^{51}$, embora muito tenha sido escrito sobre o termo democracia, há ocasiões em que interessa mantê-lo oculto, com a finalidade de reforçar condutas presentes no discurso, também por que o âmbito semântico da expressão democracia tem sido ampliado até tal ponto que dela fazem uso diversas correntes de pensamento.

Cortina $^{51}$ trabalha com a expressão Democracia Radical, que seria um aprofundamento da visão de democracia participativa, e afirma que o significado da palavra democracia poderia ser convertido no critério mais radical de crítica a nossas democracias reais. No entanto, adverte, enquanto permanecerem ocultos o significado de democracia e porque ela pode servir para dar legitimidade à dominação, continuarão os cidadãos sem capacidade crítica frente o funcionamento das democracias reais e sem força moral para cooperar em sua transformação.

A autora defende a necessidade de compreender a que se referem as ideologias políticas - socialista ou liberal - quando defendem a democracia, buscando esclarecer o que seja uma democracia sem dogmas ${ }^{51}$. A ideologia política liberal apresenta-se como o modelo ao qual parece identificar-se o Conar quando se diz portador de um espírito verdadeiramente democrático.

Com referências claras ao neoliberalismo ao contestar o papel do Estado na regulação da publicidade, o discurso do Conar defende liberdades e autonomias individuais, submetendo-as à necessidade de informação - que seria garantida, em acordo com o discurso, pela publicidade - e vinculando essas liberdades às liberdades comerciais e econômicas, quando se utiliza do "[...] porque o Conar acredita [...]" (Conar, 2012, p. 3) ${ }^{33}$, na tentativa de explicar que a liberdade individual depende da liberdade comercial.

A bioética de intervenção critica modelos que supervalorizam a autonomia em nível individual, defendendo uma ampliação da utilização do 
conceito de justiça, que busque contribuir para um modelo de organização de sociedade mais justa e equitativa ${ }^{44}$.

Como esse Conselho reflete os anseios da sociedade? Que questões envolvendo o consumo e a publicidade são de interesse da sociedade? Qual seria a melhor maneira possível? Na opinião de quem? Transparece uma contradição em relação à apresentação dos dados de denúncias e processos registrados; se o quantitativo foi considerado não especialmente alto, os anseios da sociedade podem não estar representados adequadamente pelo Conar, ou são anseios de pouca importância para o Conselho que os julga.

No entremeio do parágrafo, sutilmente insere-se os interesses reais do Conselho que representa a indústria publicitária, quais sejam, a liberdade de expressão comercial e as questões socioeconômicas, que podem ser lidos também, por fim, como lucro - objetivo primordial dos associados, como representantes de empresas privadas que são.

Note-se que, após a defesa da publicidade como relevante do ponto de vista socioeconômico, as crianças e adolescentes, antes tratados como menores de idade, agora são tornados "[...] cidadãos responsáveis e consumidores conscientes [...]" (Conar, 2012, p. 3) ${ }^{33}$, fazendo-se uma redefinição e manipulação de papéis conforme interessa ao discurso.

Essa mudança de identidade tem como efeito, perante o interlocutor, a associação das crianças e adolescentes a boas qualidades, quando expostos à publicidade; antes, eram menores de idade, mas protegidos pela autorregulamentação da publicidade, podem vir a ser cidadãos responsáveis e consumidores conscientes. O efeito do discurso é o de indução, através do que deixa implícito.

A parte final do trecho em destaque, que retoma os supostos interesses da sociedade - entrelaçada às crenças do Conar - traz como premissas de valor justamente a responsabilidade dos cidadãos, a consciência dos consumidores, que dependeriam diretamente da informação. Ainda, afirma-se 
que a falta da informação - supostamente fornecida pela publicidade - poderia prejudicar a autonomia e a liberdade de escolha.

Aqui, o discurso da autonomia é perigosamente utilizado. Qual grau de autonomia o Conar espera proteger ou promover em seus consumidores? Com qual finalidade? Apresenta-se, no texto, autonomia vinculada à liberdade de escolha, ou seja, pessoas com capacidade de compra, e suficientemente informadas pela publicidade estarão prontas para escolher o que irão comprar. Mais ainda, crianças com capacidade de escolher o que irão comprar. Essa lógica está em pleno desacordo com o princípio de proteção aos vulneráveis, tratado no âmbito da DUBDH.

Lembrando o conceito de publicidade, vemos que há muito tempo a informação não é foco de tal atividade, e sim, a promoção do lucro e a conquista de clientela. Ou seja, a publicidade não poderia ser apresentada como um serviço à sociedade, como instrumento a serviço da democracia e em prol da autonomia de da liberdade de escolha - especialmente sabendo-se que a publicidade é paga pelo consumidor, com estabelece o conceito.

O discurso traz informação irreal, buscando, como dito, fazer parecer o que não pode, de fato, oferecer, talvez à semelhança da própria atividade publicitária, como também estabelece o conceito utilizado no presente estudo. Opta-se, no discurso, por não definir claramente, ao longo do documento em análise, o que é publicidade; o que seria uma boa publicidade, ou má publicidade.

Importante referendar que a escolha dos conceitos de apoio à análise em curso traz como ideia a busca por uma lógica de pensamento descolonializada para tratar o tema da regulação da publicidade de alimentos, onde, por exemplo, a informação necessária para o dito consumo consciente não seja a informação oferecida pela publicidade.

Nascimento e Garrafa ${ }^{43}$ apontam, a respeito da colonialidade da vida e do poder, que as linhas de pensamento hegemônico - ao qual se identifica, neste trabalho, alinhamento do discurso do consumo consciente e informado - 
utilizam claramente a publicidade como dispositivo de reprodução da imagem colonizada da vida. Nessa lógica, o discurso em análise contribui, portanto, para a deterioração das questões de saúde e nutrição, a estruturação e manutenção das desigualdades sociais.

Colocando-se em defesa de nobres valores, o discurso pressupõe que seja papel do Conar contribuir com a cidadania, com a consciência, com a construção da autonomia e em defesa das liberdades - de expressão comercial e de escolha.

Esses valores são vendidos ao interlocutor por meio de uma associação aos objetivos do Conselho, funcionando como publicidade da própria publicidade. No entanto, o tipo de informação e de empoderamento necessário ao reforço da autonomia de crianças e adolescentes não é ofertado pela publicidade. Contrariando princípios bioéticos como o da proteção aos vulneráveis, a publicidade é uma influência indevida sobre as possíveis decisões ou escolhas alimentares de crianças e adolescentes, e prejudica-lhes a autonomia. Sabe-se, também, que a liberdade para realizar escolhas alimentares é influenciada por fatores outros além da informação disponível; é determinada pelo poder de compra e é influenciada pelas tradições culturais, preferências, hábitos, e até mesmo pelas mensagens publicitárias.

Percebe-se, então, a ocorrência de manipulação do interlocutor, utilizando-se de conceitos difusos com a intenção de conferir pleno suporte ao discurso.

O ponto que caberia ao Conar defender, ou colocar à venda, seria apenas a liberdade de expressão comercial - conceito criado como parte do processo de significação utilizado pelo Conar na construção de seu discurso. Trata-se de uma estratégia denominada nominalização, que é a naturalização de um artefato discursivo. O Conar produz um significado, em alusão ao direito constitucional de liberdade de expressão, para uma liberdade de expor ao público o que se quer comercializar. É a utilização de uma fórmula feita, sem discussão do significado dessa expressão. 
Como efeito, as construções simbólicas destacadas, naturalizadas e reforçadas no e através do discurso - publicidade ética de nascença, DNA ético, liberdade de expressão comercial - vão se tornando parte de um interdiscurso ou discurso coletivo sobre o tema, apoiando e determinando futuros discursos, estabilizando e cristalizando-se na memória discursiva coletiva.

\subsubsection{Segunda Seção - A publicidade brasileira é uma atividade que traz a ética em seu DNA}

Seguindo pela ordem apresentada no documento, a segunda seção apresenta, em seu título, uma reformulação explícita sobre o que é a publicidade:

A publicidade brasileira é uma atividade que traz a ética em seu DNA (Conar, 2012, p. 4) ${ }^{33}$.

Não se trata de um conceito, mas de uma forma de caracterizar a publicidade, associando a ética à constituição primária da atividade. Utilizando a expressão DNA, já no título da seção, o discurso cria um coeficiente simbólico sobre a publicidade, utilizando o nome atividade para designar a publicidade com um nome diferente e retratando-a como ética por essência.

Essa seção traz como diferencial marcante em relação à anterior 0 questionamento sobre a responsabilidade pela educação de crianças e adolescentes e a apresentação de pontos que buscam alinhamento a outros discursos, aparentando afinidade com instrumentais de proteção.

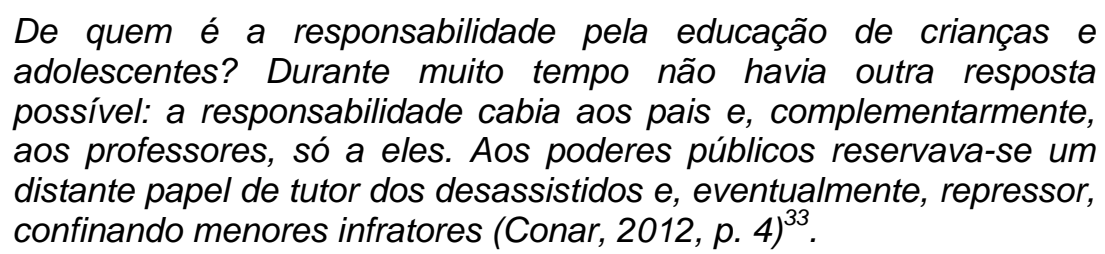

Vincula o Estado, em algum tempo passado, à repressão, confinamento de menores infratores e tutoria de desassistidos, distante da responsabilidade 
pela educação. Reduz e discrimina, pela escolha das palavras, crianças e adolescentes em conflito com a lei, a menores infratores. Não confere significado a questões sociais, como se fossem mero acaso histórico; eventuais, como expressa o discurso.

A opção de utilização de um termo como desassistidos, evitando menção aos processos de exploração e dominação de uns sobre outros é apontada por Dahlet ${ }^{52}$ como eufemismo, forma utilizada pelo discurso neoliberal em tentativa de apagar as divisões sociais e eliminar os conflitos existentes - ao menos no âmbito do discurso. Apesar de manifestar a desigualdade, o termo reforça o apagamento da divisão, ao não permitir condição de mudança, de questionamento. Silenciando os agentes e os alvos de produção da desigualdade, o discurso produz um efeito de reduzir a inquietude que possa gerar nos dominantes e a rebelião nos dominados, de acordo com o autor.

O trecho que segue coloca o Conar como discordando que a educação caiba somente aos pais e professores, além de elevar o status dos menores a crianças e adolescentes, agora como merecedores de uma preocupação:

Felizmente, esse entendimento geral mudou. A sociedade brasileira e
mundial viu crescer nas últimas décadas uma extraordinária
preocupação com a formação e o bem-estar de crianças e
adolescentes (Conar, 2012, p. 4)

Não são quaisquer menores, os merecedores dessa preocupação; não os menores infratores, mas as crianças e adolescentes.

Ao utilizar a palavra extraordinária para definir uma preocupação crescente com as crianças e adolescentes, o discurso, no entanto, parece discordar que seja realmente um público merecedor de tal esforço social, por ser a preocupação fora do comum. A sociedade é colocada no discurso como um ente passivo, que apenas viu crescer a preocupação, e não como quem participou da construção ou compartilhou dessa preocupação. O termo "nada" aparece na frase seguinte, por duas vezes:

Nada mais justificado, nada mais louvável (Conar, 2012, p. 4) ${ }^{33}$. 
Aqui, o discurso busca uma aproximação a tal preocupação, admitindo que seja justificada e até louvável - embora apresentando duas vezes a palavra nada nessa construção, de onde se pode subentender uma negação da validade da preocupação com a infância.

Ainda, o discurso constrói a ilusão de que mudou também a situação global da infância, ignorando que ainda há pobreza, discriminação e abandono, crianças sofrendo de fome e falta de acesso a condições de saúde e educação no mundo. A representação social da realidade construída pelo discurso do Conar ignora e apaga a persistência de questões relativas à infância como problemas sociais.

O discurso segue a construção da própria realidade, colocando-se alinhado à necessidade de educação formal e social como instrumentos para vencer futuros desafios da humanidade.

O futuro encerra múltiplos e decisivos desafios para a humanidade, que só poderão ser vencidos se nossos jovens receberem educação formal e social para tanto (Conar, 2012, p. 4) ${ }^{33}$.

$\mathrm{Na}$ tentativa de criar a ilusão da existência de vínculos, e de um sujeito coletivo, utiliza-se o pronome pessoal nossos para designar os agora denominados jovens, colocando o Conar em lugar enunciativo que o une à sociedade de maneira positiva, vencendo os desafios. Ao deixar indefinido quem são esses jovens, e quais são os desafios, o discurso condiciona o futuro a outro termo indefinido, qual seja, a educação social.

Jogam-se os desafios para o futuro, como se já não estivessem colocados à humanidade no presente. Como se a preocupação extraordinária e a educação fossem elementos de uma poupança para algo indefinido que ainda está por vir, e que deverá ser enfrentado por outros. Esse recurso de mitificação do futuro, ligado à incerteza por conta dos desafios, intenciona vender uma proposta de educação social que está oculta. Nota-se a presença de um pretenso discurso global, que indistintamente se preocupa com os jovens, no entanto, retira-Ihes a historicidade, visto que há pouco eram designados com outros nomes dentro da mesma seção. 
A perspectiva de futuro contida no discurso se apresenta conflituosa com a tese da ética de responsabilidade, ponderando o que aponta Hans Jonas ${ }^{20}$ sobre as ações que têm projeção causal em direção ao futuro. O filósofo entendeu que, no âmbito da moralidade, a ação humana deve ser capaz de projetar uma consciência prévia que busque, em vez de desvendar ociosamente as consequências futuras, ter em conta a magnitude dos impactos de longo prazo e a sua frequente irreversibilidade. Isso implica, para Jonas, deslocar a responsabilidade para o centro da ética.

No trecho apresentado em sequência, aparecem empresas e voluntários, sem menção ao Estado, cujo papel só foi destacado em relação ao que era, no passado. Assim, constrói-se no discurso o apagamento enunciativo do Estado, como grande ausente nas ações de proteção e educação, como se o voluntariado e a ação empresarial pudessem dar conta dessas ações. Evidencia-se o reforço à noção de Estado Mínimo, concepção vinculada à ideologia neoliberal, como uma situação dada, naturalizada.

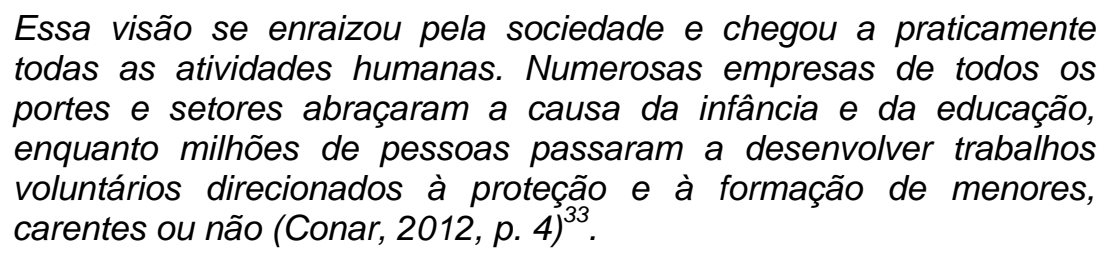

Há uma tentativa de fazer supor que a visão do Conar é a que prevalece, em todas as atividades humanas, de maneira determinante, enraizada, quando se aponta que a visão de responsabilidade social se enraizou pela sociedade.

Os jovens agora voltam a ser denominados menores, como no início da seção. A utilização da vírgula permite distinção entre os menores, já discriminados pela escolha da palavra, mas ainda podendo ser diferenciados entre carentes ou não. Haverá tratamento diferencial para esses menores? Pode-se, por meio do discurso, fingir que estão em posição de igualdade, mas a afirmação demonstra a intenção de marcar a diferença.

Adiciona-se a publicidade, como ente não indiferente, relevante como atividade e fonte financiadora das comunicações no país. 
A publicidade não poderia ficar indiferente a tal mobilização. Afinal, multiplicou-se nas últimas décadas a relevância dessa atividade, sendo ela a principal base de financiamento da extraordinária aceleração das comunicações no país (Conar, 2012, p. 4) ${ }^{33}$.

Apresentam-se novos dados numéricos na tentativa de justificar a relevância social da publicidade, pontuando historicamente momentos como o surgimento de regulamentos atinentes à atividade e enaltecendo características do código de autorregulamentação.

Essas reformas se deram após um processo de amadurecimento e discussão de cada tema com numerosos interlocutores, inclusive autoridades e os elos do mercado publicitário. Definidas, as normas entram em vigor já em consenso com o mercado e sem nenhum ônus para o governo, em todas as suas instâncias (Conar, 2012, p. 5) ${ }^{33}$.

A utilização desses recursos demonstra o modus operandi do discurso, como forma de construção da realidade, materializando-a por meio das palavras, ao definir o papel da publicidade, marcar sua importância, seu enraizamento, suas qualidades e demonstrar a existência de consenso em torno de seu conteúdo. Dessa maneira, o Conar constrói sua perspectiva de mundo, seu universo de significações, que assim se inscreve no interdiscurso, entre tudo o que já se disse sobre a publicidade e tudo o que ainda será dito.

Dahlet $^{48}$ avalia que a reprodução de valores e práticas discursivas até mesmo entre meios marcadamente opostos em ideologias - a onipresença em espaços discursivos - se deve ao fato de seus suportes e articulações passarem despercebidos, sendo assim tomados por perspectiva universal, global.

\subsubsection{Terceira Seção - 0 sistema misto de legislação e autorregulamentação provê a segurança que convém ao consumidor}

A terceira seção do documento apresenta conviç̧ões para defender a utilidade da publicidade como fonte de informação para o consumo consciente, 
sua contribuição como atividade para o crescimento da economia e uma explanação sobre o processo de revisão do Código de autorregulamentação.

O Conar traz à tona o Código de Defesa do Consumidor, evocado como saber compartilhado sobre o qual pretende se fundamentar por meio da tentativa de associação do discurso à representação do Código:

Nunca é demais lembrar que o Código de Defesa do Consumidor prevê a pena de prisão para o anunciante que levar o consumidor a engano (Conar, 2012, p. 6)

O discurso apresenta uma defesa da publicidade livre e ética, fazendo um julgamento que visa caracterizar de que publicidade se está tratando; deixa implícito que possam existir outros tipos de publicidade, com características diferentes dessa que se defende.

A motivação do Conar em defesa da publicidade livre e ética apenas
sublinha a necessidade absoluta de sintonia entre o Código Brasileiro
de Autorregulamentação Publicitária e os anseios da sociedade
(Conar, 2012, p. 6) $)^{33}$.

O Conar cita estudos, inespecíficos, como vozes de autoridade em apoio ao seu discurso, e trabalha valores positivos em associação à publicidade:

Numerosos estudos comprovam a força da publicidade como motor de mercados, de qualidade de vida, de crescimento material e humano (Conar, 2012, p. 6) ${ }^{33}$.

Em sequência, retoma-se a defesa da publicidade como meio de informação, mito que já fora examinado à luz do conceito de publicidade que vem sendo utilizado em apoio à presente análise. Trata-se de um lugar-comum, afirmar que as pessoas poderiam consumir melhor quando providas de informação, utilizado como recurso pelo discurso a fim de fundamentar consensualmente sua proposta de obtenção de lucro por meio da publicidade.

Além desse reforço a uma informação inverossímil, fala-se em um processo de consumo, associando-o com palavras atrativas, supostamente de interesse do consumidor (novidades, vantagens, brindes, entre outras), e ainda, apresentando como implicações do dito processo, valores muito caros para a sociedade, como conforto e segurança, caracterizando manipulação por meio do discurso. Na base desse trecho do texto está a inferência de que as 
pessoas queiram ou devam consumir; a pessoa - e também a criança e o adolescente, focos do discurso presente no texto - são tomados, como pressuposto discursivo, por consumidores.

As pessoas consomem melhor com informação. $O$ processo de consumo começa, normalmente, nos meios de comunicação, com a oferta de novidades, vantagens, especificações, preços, descontos, parcelamentos, brindes etc., que geram facilidades, comodidades, conforto, segurança etc (Conar, 2012, p. 6) ${ }^{33}$.

Aparece, como forma discursiva, nova reformulação da palavra publicidade, utilizando metáfora a respeito da concorrência, e da construção de implicação de que a concorrência é, por sua vez, benéfica para o consumidor:

Publicidade é sinônimo de concorrência, e concorrência é garantia de melhores condições para o consumidor (Conar, 2012, p. 6) ${ }^{33}$.

Reiterando a finalidade da publicidade, que é essencialmente lucrativa, percebe-se que as formas discursivas utilizadas e o destaque da vantagem para o consumidor têm a função de dissimulação ideológica dos reais interesses dos sujeitos de fala.

\subsubsection{Quarta Seção - A solução para a epidemia de obesidade infantil passa pela família, educação - e também pela autorregulamentação}

A quarta seção traz como tema central a obesidade infantil, caracterizada como epidemia, e sua relação com a publicidade de alimentos. $\mathrm{O}$ título da seção parece tentar referendar o Conar como autoridade no tema, apontando literalmente uma solução para a obesidade, hierarquizando responsabilidades entre família, educação e autorregulamentação.

A expressão autorregulamentação, presente desde o nome do Conselho, pode também ser vista como uma nominalização, e a forma como está colocada no título da seção implica o entendimento de que as famílias têm o dever se autorregular. Essa responsabilidade não é debatida no texto, porém, fica implícita como parte inicial da solução proposta para a obesidade, e cabe 
plenamente no contexto do discurso de base neoliberal. Por outro lado, no âmbito do documento, fica notória também a defesa da autorregulamentação como um direito do Conar, que a criou como proposta de enfrentamento à possibilidade de censura.

Destaque à multicausalidade como característica da obesidade, que faz parte do discurso científico, do mesmo modo que a caracterização da obesidade como epidêmica.

[...] problema complexo com origem em múltiplos fatores (Conar, 2012, p. 8) ${ }^{33}$.

Como em diversos outros pontos do discurso, no entanto, fica em aberto o entendimento da multicausalidade da obesidade, vez que essa premissa não foi explicitada ao leitor do texto. Possui, no entanto, o peso da ciência, que é utilizada em apoio à justificativa que se tenta construir, no discurso, de que a publicidade e a obesidade não possuem associação explícita ou direta. São muitos os fatores, e a publicidade pode estar distante, nessa perspectiva.

O discurso faz menção a estudos e processos decisórios havidos em outros países, utilizados com vozes de autoridade em apoio à justificativa de irrelevância e contrariamente à regulação estatal. Traz também a OMS no mesmo sentido, distorcendo informação conforme interessa ao discurso:

A Organização Mundial da Saúde, por sua vez, não emitiu diretiva
propondo o banimento da publicidade de alimentos e refrigerantes ou
de restrições a ela como política pública, preferindo propor
recomendações gerais a serem adotadas pelos seus
Estados-membros, frisando a necessidade de uma abordagem
multidisciplinar. A posição atual da OMS é no sentido de mobilizar
todos os inúmeros agentes com influência para a solução do
problema (Conar, 2012, p. 9) ${ }^{33}$.

Como organismo internacional, a OMS não emite diretivas, mas sim elabora relatórios e recomendações aos países membro, e não se trata de uma preferência, como anuncia o discurso, mas do papel da organização que consiste em transferência de tecnologia e difusão do conhecimento em saúde pública. Documentos elaborados pela OMS e sua representante regional para as Américas, a Organização Panamericana de Saúde (OPAS) acerca da obesidade e da publicidade de alimentos para crianças, conforme referências, 
são categóricos em afirmar a relevância fundamental de políticas públicas regulatórias na área ${ }^{8,9,10}$.

A solução apontada pelo Conar, no entanto, novamente propõe - por meio de inferência - o apagamento do papel do Estado no processo de regulação da publicidade. A partir dos referenciais da bioética de intervenção como abordagem teórica politizada e comprometida com os direitos das populações excluídas do desenvolvimento econômico, tem-se, no entanto, que o papel do Estado é fundamental na proteção dos interesses das pessoas em situação de vulnerabilidade, questão explicitada no referencial teórico.

O Conar apresenta um contraponto a outros discursos nesse sentido, sem a devida honestidade com relação às diversas propostas de regulação em curso no país - nem todas proibitivas da publicidade:

\begin{abstract}
No entanto, para muitos, anúncios de alimentos e refrigerantes tornaram-se vilões que precisam ser banidos com a maior brevidade possível e sem maiores discussões, como se essa medida fosse capaz de acabar com a obesidade. Esta tese não está prosperando (Conar, 2012, p. 8) ${ }^{33}$.
\end{abstract}

Referem-se aos alimentos e refrigerantes anunciados sendo vistos como vilões, e desfiguram as propostas de regulação, como se o contradiscurso tivesse o objetivo de banimento da publicidade e considerasse que tal ação seria capaz de resolver o problema da obesidade. O discurso emprega recurso mítico, e apaga o debate sobre a regulação e sobre a qualidade dos alimentos e refrigerantes mencionados. Também não revela de quem se trata o sujeito denominado muitos.

No que se refere à promoção de práticas alimentares saudáveis como papel do Estado, tem-se utilizado o tratamento terminológico de produtos alimentícios para designar alimentos com alto grau de processamento industrial, ou alimentos ultraprocessados ${ }^{7,26}$. Trata-se de um contradiscurso que vem sendo construído com a finalidade de marcar as diferentes características e implicações à saúde, possivelmente influenciado por discursos como este em análise, que afirmam que se um alimento tem registro sanitário aprovado no país, é pressupostamente bom, portanto, não deve ser 
demonizado nem ter sua divulgação proibida. É interessante perceber que essa relação dialógica ocorre entre discursos anteriores e futuros, conforme Orlandi $^{45}$.

\subsubsection{Quinta Seção - Uma breve história do Conar}

Na quinta seção, que trata do histórico de fundação do Conselho, afirmase que o Conar e seu código foram criados a partir de uma ameaça à atividade publicitária, quando, no final dos anos 1970, havia a possibilidade de criação de uma Lei de censura prévia à propaganda. Aponta-se que, então, a proposta de autorregulamentação surgiu como resposta, dotada de inspiração, à censura, com o propósito de cuidar dos interesses do consumidor.

O Conar e seus representantes se reconhecem como vítimas da censura, ressaltando, no entanto, suas características como grupo combativo, em defesa de nobres princípios como a liberdade de expressão comercial e os interesses do mercado publicitário. Identificam sua ação, nesse sentido, como inspirada e de sucesso.

Diante dessa ameaça, uma resposta inspirada: autorregulamentação, sintetizada num Código, que teria o propósito de zelar pela liberdade de expressão comercial e defender os interesses das partes envolvidas no mercado publicitário, inclusive os do consumidor (Conar, 2012, p. 10) ${ }^{33}$.

Ao final, foi acrescentado o consumidor como uma parte envolvida nesse mercado. Utiliza-se aqui a ferramenta do esquecimento, mencionando o consumidor apenas como parte do mercado publicitário, tão distante como partícipe da ameaça de censura à propaganda quanto da resposta inspirada representada pela autorregulamentação.

Analisando o contexto em que se insere no mercado de consumo, e com base nas definições de publicidade ora em debate, é possível perceber que o envolvimento do consumidor dá-se como o expropriado, submetido à publicidade sem nunca sequer ter sido questionado se a queria, se realmente 
possui algum interesse em tal mercado, para além de ser seu refém. Ademais, nenhuma fatia econômica desse mercado jamais the coube. Ainda, a supervalorizada liberdade de expressão comercial apenas o torna, mais uma vez, submisso aos interesses do mercado, pois ao submeter-se ao produto da expressão comercial, ele tem a sua liberdade de escolha invadida, influenciada, subjugada. Assim funciona a publicidade, retomando novamente o conceito: paga pelo consumidor, voltada ao lucro e à conquista de novos consumidores.

O discurso segue designando como sujeitos que falam um conjunto de entidades representativas do mercado publicitário, como se verá, de setores que detêm grande poder econômico e midiático no país, listadas conforme segue: ABA - Associação Brasileira de Anunciantes; ABAP - Associação Brasileira de Agências de Propaganda; ABERT - Associação Brasileira de Emissoras de Rádio e Televisão; ANER - Associação Nacional de Editores de Revistas; ANJ - Associação Nacional de Jornais; Central de Outdoor; ABTA Associação Brasileira de Televisão por Assinatura; IAB Brasil - Interactive Advertising Bureau e FENEEC - Federação Nacional das Empresas Exibidoras Cinematográficas.

O lugar enunciativo do discurso do consumo consciente e informado é coerente com a defesa que fazem dos direitos, quais sejam, a liberdade de expressão comercial e os interesses do mercado publicitário. Questionável é a menção ao consumidor como parte envolvida nesse mercado. Questiona-se também quem é esse consumidor a que o documento se refere. Crianças e adolescentes não podem ser vistos como meros consumidores, mas antes como vulneráveis que são em relação à exposição à publicidade, conforme exposto e defendido ao longo do presente trabalho.

A sequência da história narrada no discurso do Conar aborda a implementação do Código de autorregulamentação como uma ideia de sucesso:

Num espaço de poucos meses, anunciantes, agências e veículos subordinaram seus interesses comerciais e criativos ao Código, solenemente entronizado durante o III Congresso Brasileiro de 
Propaganda, em 1978. Nunca mais o abandonariam (Conar, 2012, p. $10)^{33}$.

A menção ao consumidor como parte interessada no mercado publicitário desaparece completamente do discurso, demonstrando que, provavelmente, não há real interesse do e no consumidor no cenário descrito exceto como sujeito a ser conquistado pelas ações publicitárias.

Sugere-se que a memória dos sujeitos de fala, representados pelo Conar, esteja marcada pela restrição de sua atividade econômica - ou de seus interesses comerciais - com a censura, motivo pelo qual se utilizam do discurso para apontar tentativas de regulamentação estatal da publicidade em alinhamento à ideia de retorno da censura. Por isso se unem, por isso apresentam seu manifesto, publicizam o que pensam, e o fazem com o conhecimento e a expertise dos melhores profissionais da área de publicidade. Sabem fazer vender, marcas e ideias.

O Conar detém a força do capital de "[...] cerca de quatrocentas empresas a ele associadas" (Conar, 2012, p. 11) ${ }^{33}$. Aqui, destaca-se a identidade de quem fala, que por meio de relações de força e pela posição hierárquica, faz com que o discurso se imponha e produza sentidos:

As decisões do Conar nunca foram desrespeitadas. Nas raras vezes em que foram questionadas na Justiça, o Conar saiu-se vitorioso (Conar, 2012, p. 10) ${ }^{33}$.

As palavras utilizadas são marcadores de conflito, cristalizam o Conar como vitorioso e sua ação como inquestionável no âmbito do interdiscurso a respeito da publicidade. Esse efeito do discurso é um dos esperados por quem o produz, a materialização discursiva, o inscrever na história a sua marca.

De acordo com Francisco Forjaz ${ }^{53}$, forçar o debate a respeito dos limites legais - e, no caso, das raras ações judiciais promovidas pelo Conar - afasta a necessária discussão acerca de limites éticos para a publicidade direcionada a crianças e adolescentes. 
Aparece contradição no discurso, no uso dos termos nunca e raras vezes. Mostram-se números de processos éticos instaurados (oito mil desde a entronização do Código de ética do Conar até a publicação do documento em análise), cita-se um "[...] sem-número de reuniões de conciliação entre associados em conflito" (Conar, 2012, p. 10) ${ }^{33}$. Lembrando que, na primeira seção do documento, utilizou-se exatamente o número de reclamações e peças julgadas, tido como não especialmente alto, para caracterizar como ética de nascença a publicidade brasileira.

Essas contradições aparecem apesar da tentativa de fazer o discurso parecer homogêneo. No fim, o que parece importar mais, em destaque, é que o Conar saiu-se vitorioso, marcando sua posição por meio da discursividade. Conclama-se a Justiça, como voz de autoridade, situada na fala estrategicamente em sequência à designação Conar, como recurso de associação, buscando deixar a contradição para trás. Some o consumidor, não sendo possível saber se também vitorioso ou derrotado com as decisões do Conar.

Acompanha a frase em destaque na página a foto de uma menina, dessa vez de frente, encarando o leitor, pendurada em um galho de árvore e portando meio sorriso, com uma expressão desafiadora, modo pelo qual o discurso estético reforça a mensagem escrita. Faz-nos parecer, então, que o consumidor também se sai vitorioso, como a menina.

Ainda na seção do documento que apresenta a história do Conselho, listam-se os preceitos que definem a ética publicitária, como parte de um quadro intitulado Como funciona o Conar. São eles:

- todo anúncio deve ser honesto e verdadeiro, bem como respeitar as leis do país;

- deve ser preparado com o devido senso de responsabilidade social;

- deve ter presente a responsabilidade da cadeia de produção junto ao consumidor;

- deve respeitar o princípio da leal concorrência;

- deve respeitar a atividade publicitária (Conar, 2012, p. 11) ${ }^{33}$.

Os preceitos parecem ser imputados ao anúncio - que ganham status personalizado, devendo ser honestos e verdadeiros - e não aos anunciantes ou 
às agências produtoras dos anúncios. O único ser humano presente no discurso de preceitos da ética publicitária é o consumidor, mesmo assim, passivo.

Poderíamos questionar sobre o que seria um anúncio verdadeiro em relação ao produto, imaginando como exemplo um anúncio de chocolate, que informaria sobre a característica do produto como ultraprocessado, nutricionalmente pouco saudável, rico em gorduras, açúcares, que seu consumo excessivo está relacionado à obesidade, cáries e outras doenças não transmissíveis, com alta prevalência e que são, atualmente causadoras de mais de $70 \%$ das mortes no país. Por certo, essa hipótese não é a mais provável; seria então apresentada uma verdade construída, à semelhança de diversos trechos do discurso do Conar?

Está presente também a expressão responsabilidade social, na devida medida, o que deixa a inferência de que pode haver responsabilidade social desmedida, indevida ou talvez exagerada. Outro conceito sem definição, não dialogado, que seria de grande relevância para o aprofundamento da compreensão da perspectiva ética do discurso. Responsabilidade também é imputada à cadeia de produção, embora seja possível apenas inferir do que se trata, possivelmente, a cadeia de produção de bens ou de serviços anunciados.

Trazemos novamente para apoiar a análise do discurso as contribuições de Jonas $^{20}$, que afirma que a reflexão ética de nossos dias está repleta do "[...] algodão das boas intenções e dos propósitos irrepreensíveis, o declarar-se do lado do bem e contra o pecado, pela prosperidade e contra a destruição" (Jonas, 2006, p. 23). Ele atenta para o fato que tais motivações não podem apresentar insuficiência argumentativa, o que se percebe constantemente no discurso em estudo.

A palavra respeito é utilizada três vezes dentro da lista de princípios, em referência às leis do país, ao princípio da leal concorrência e à atividade publicitária. Ora, o respeito às leis é obrigatório; as expressões leal concorrência e atividade publicitária não estão definidas, embora, como parte 
do contexto do discurso, seja possível inferir que não estejam referenciadas pelos interesses do consumidor, mas antes pela lógica do capital.

Dahlet $^{52}$ nos incita a buscar a emancipação da retórica que traz a eufemização como ferramenta, como parte de uma linguagem que quer fazerse parecer ética, transparente e eficaz; uma linguagem que nos induz ao consumo sem freios, nem sempre possível de ser realizado. Nesse sentido, misturam-se o discurso em análise e o objeto de sua defesa, ou seja, é necessária uma reação ao próprio discurso publicitário, como parte do interdiscurso neoliberal, globalizante, fabular, que, segundo o autor, está a serviço de "[...] um sistema que desarticula precisamente o tempo da emancipação [...]" (Dahlet, 2014, p. 136).

Em seguida à referência aos princípios e preceitos éticos, aparece novamente o consumidor, como possível formulador de denúncias, ao lado de autoridades, empresas associadas e da própria diretoria do Conar. O discurso segue explicando como funciona o procedimento de atendimento a denúncias de descumprimento do Código, julgadas por um Conselho de Ética do Conar, cuja composição é assim descrita:

O Conselho de Ética está dividido em oito Câmaras, sediadas em São Paulo, Rio, Brasília, Porto Alegre e Recife, e é formado por 180 conselheiros, entre representantes da sociedade civil - pessoas que se destacaram na defesa do consumidor ou no estudo das relações de consumo - e publicitários. Todos trabalham para o Conar em regime voluntário (Conar, 2012, p. 11) ${ }^{33}$.

O número de conselheiros chama a atenção pela expressividade, além do destaque dado aos publicitários, como se não fossem parte da dita sociedade civil; essa estaria representada por "[...] pessoas que se destacaram na defesa do consumidor ou no estudo das relações de consumo" (Conar, 2012, p. 11) $)^{33}$. Presume-se que possivelmente os estudiosos de relações de consumo sejam pessoas com interesses no mercado publicitário; resta saber quem são os representantes do Conselho de ética do Conar que possuem destaque na defesa do consumidor. Note-se também a utilização da expressão "[...] trabalham para o Conar [...]" (Conar, 2012, p. 11) ${ }^{33}$ para designar a participação voluntária dos representantes no Conselho em questão. 
Esse trecho do texto parece entrar em contradição com um anterior, em que o Conar se alinha aos jovens, utilizando a expressão nossos jovens, pois o Conselho de Ética é abordado guardando-se certa distância do Conar, em tentativa de gerar inferência de que se trata de órgão que não sofreria influência direta dos dirigentes do Conselho.

Em pesquisa complementar realizada no site do Conar $^{54}$, estão listados 20 membros do Conselho de ética, identificados genericamente como representantes da sociedade civil. Ao lado dos respectivos nomes, entre parênteses, está identificada a formação ou qualificação de 18 entre os 20. Ainda, clicando-se sobre o nome de cinco deles, visualiza-se um mini currículo.

Dos 18 com formação identificada, tem-se: um advogado, cinco jornalistas, cinco professores, três médicos, uma pesquisadora, um jornalista e professor, um engenheiro e professor, um administrador e professor. Os mini currículos apresentam um diretor de jornalismo de importante emissora de televisão (identificado como jornalista), um sócio diretor de uma consultoria de marketing (identificado como professor), um médico que escreve artigos para um dos maiores jornais do país desde 1960, o diretor geral da Escola Superior de propaganda e marketing (professor) e um profissional de marketing que é membro do Conselho de Ética do Conar desde os anos 1980 (identificado inicialmente como administrador e professor).

Esses são os sujeitos que fiscalizam, julgam e deliberam as denúncias feitas ao Conar. No site e em diversos boletins do Conselho, é possível conhecer parte dos trâmites de ações por ele julgadas.

Embora a composição do conselho não esteja discriminada no âmbito do documento de onde se analisa o discurso, depreende-se que os membros do Conselho de ética, dada sua inserção profissional e social, tenham total interesse em legitimar as ações dos anunciantes representados pelo Conar, entendendo-se que o julgamento por pares posa ser comparado a uma ação entre amigos. O mesmo grupo de amigos que, de seu lugar enunciativo, defende a suficiência da autorregulamentação. 
Ainda que representantes da sociedade, são pessoas alinhadas à mesma ideologia do discurso do consumo consciente e informado, o que torna questionável a veracidade de representação dos interesses do consumidor e, por fim, levanta suspeição acerca da validade dos julgamentos realizados pelo Conselho de ética do Conar. Em última análise, revela-se o conflito de interesses presente e transparece um discurso que, em seu conjunto, carece de credibilidade, embora se diga ético.

Cabe um alerta à sociedade a respeito da representatividade desses membros, entendendo que se trata de um Conselho que não representa os interesses do consumidor, fato que poderia gerar denúncia a órgãos como Ministério Público. 


\section{CONSIDERAÇÕES FINAIS}

A análise do discurso do consumo consciente e informado permitiu caracterizar uma perspectiva ética de comprometimento com ideais relacionados ao mercado, à livre concorrência, ao predomínio das relações de consumo sobre a vulnerabilidade de crianças e adolescentes, e a valores que pretendem apagar o papel do Estado na proteção da saúde e distanciá-lo do controle da atividade publicitária, ou seja, ideais fortemente vinculados ao contexto neoliberal.

O discurso analisado mostrou alinhamentos e posicionamentos éticos que falam de interesses e representações presentes em nossa sociedade, em meio, certamente, a muitos outros, que se cruzam, interpõem-se, retomam-se, reforçam-se mutuamente e, por vezes, contrapõem-se.

A argumentação empreendida no texto foi de difícil identificação, pelo excesso de retórica, afirmações e premissas não discutidas, que terminam por perder o valor de verdade e não permitem inferir as conclusões enunciadas e os propósitos pretendidos.

Através da análise do discurso, delineou-se uma forma discursiva que utiliza como recursos naturalização, inverossimilidade, dissimulação ideológica, eufemização, por meio dos quais se constrói um universo de significações que serve aos interesses de quem o produz.

O discurso analisado se constrói com base em associações, muitas vezes míticas, e formas discursivas que se repetem, como reformulações conceituais, inferências e pressupostos não debatidos, não qualificados no texto. Esse padrão de discursividade é estabelecido pela relação com outros discursos, prévios, e aponta para outros, como nos ensina Orlandi ${ }^{45}$. É dessa maneira não dialógica e mesmo carente de veracidade que o discurso do consumo consciente e informado se inscreve simbolicamente na história e produz seus sentidos. 
Estão presentes como constantes no discurso, ainda, o apagamento dos conflitos sociais, a desconsideração de perspectivas históricas e o ocultamento das enunciações, gerando como efeito a chamada "reprodução do inquestionável"48, a construção de verdades que não se questiona. Utilizando esses recursos e formas discursivas, o Conar torna seu discurso palatável e permeável nos mais diversos âmbitos onde ele for reproduzido, à semelhança de como opera o discurso midiático.

Trata-se de discurso que não se alinha aos princípios apreçados pela bioética de intervenção, em especial ao princípio de proteção aos vulneráveis, e ao princípio da responsabilidade de Hans Jonas.

As propostas de autorregulamentação tampouco são convergentes para a promoção da alimentação adequada e saudável e ampliação da autonomia diante das escolhas, um dos principais propósitos das políticas públicas na área de Segurança Alimentar e Nutricional. A atuação do Conar nesse sentido é avaliada como divergente em interesses, tendo em conta os objetivos da publicidade, relacionados ao lucro e não à promoção da cultura alimentar, do acesso físico e financeiro a alimentos de qualidade ou a instrumentalização para ampliação da autonomia diante das escolhas alimentares.

Considerando, conforme aponta Mari ${ }^{55}$, que a análise de discurso como instrumental não possui a precisão de uma balança, admite-se que a pesquisa apresenta limitações, no sentido do posicionamento de quem realiza a análise, comprometida, de partida, com determinados pressupostos - no caso, com os vulneráveis, com o lado mais frágil da questão. Em contrapartida, a análise realizada pode contribuir para reforçar a perspectiva de proteção aos vulneráveis, tão cara para as bioéticas que se pretendem críticas, radicalizando o entendimento de que o Estado deve sim ter atuação reguladora da atividade econômica em estudo.

De maneira a complementar a presente abordagem do tema, seria de utilidade avaliar outros discursos, buscando também reconhecer seus modos de reprodução e geração de sentidos, como o próprio discurso da alimentação 
saudável, que apresenta várias nuanças, se utiliza de sustentação científica e é amplamente divulgado pelas diversas mídias.

Acredita-se ter contribuído, como profissional que atua em saúde pública, com o entrelaçamento entre a nutrição e a bioética como campos que se dedicam a pensar e a propor condições dignas de vida, partindo de visões que reconhecem a determinação social dos processos de saúde e adoecimento, e mais especificamente, das condições para o alcance da Segurança Alimentar e Nutricional.

Nesse sentido, cabe reforçar que o Direito Humano à Alimentação Adequada é direito a ser garantido pelo Estado, devendo ser assegurado por meio de políticas públicas intersetoriais, com reforço à participação popular em sua construção, como vem buscando construir o Brasil na área de Segurança Alimentar e Nutricional - com avanços importantes como a formulação de grandes marcos legais na área, a implementação dos programas de transferência de renda, ampliação do acesso à alimentação - especialmente a alimentação escolar - e à água, porém, com grandes tarefas de enfrentamento por cumprir, notadamente em áreas como a reforma agrária, o controle do uso de agrotóxicos e transgênicos na produção de alimentos e a regulação de sua publicidade.

Aponta-se, por fim, que a perspectiva ética do discurso analisado representa um duplo paradoxo, por tratar-se de discurso empresarial, com objetivo comercial, mas que apaga seu enraizamento competitivo e orientado pelo lucro e metamorfosa-se em discurso ético, buscando a visualização e recepção pelo interlocutor como tal.

Há que investir nas utopias emancipatórias, opondo-se ao discurso da fábula que aliena e desconstrói os sonhos, como aponta Dahlet ${ }^{52}$. Entende-se que o reforço a essas utopias pode ser conquistado justamente por meio do uso e da difusão, como prática que transforma a realidade do mundo, do discurso das bioéticas com posicionamento crítico, alimentando as lutas pela dignidade e em defesa dos vulneráveis - que somos todos diante de discursos e poderes que nos oprimem. 
Ajuizando, dos pontos de vista legal e ético, que a criança em sua vulnerabilidade deve ser, com a máxima prioridade, protegida pelo Estado, entende-se que o fato de haver dúvidas acerca da pertinência da ação regulatória sobre a publicidade que tem a criança como alvo significa valorizar outros interesses adiante da necessidade de proteção. Considera-se dada a pertinência; o que está em jogo é a disposição do Estado em enfrentar os poderosos interesses em contrário, aqui representados pelo discurso do consumo consciente e informado. 


\section{REFERÊNCIAS}

1) Ramos FRS. A Bioética como ferramenta de interpretação da realidade: entre o universalismo e o pluralismo. In: Porto D, Garrafa V, Martin GZ, Barbosa SN. Bioéticas, Poderes e Injustiças - 10 anos depois. Brasília: Conselho Federal de Medicina, Cátedra Unesco de Bioética, Sociedade Brasileira de Bioética; 2012. p.143-151.

2) Veiga E, Pannuzio E, Cunha T, Garrafa V. A legitimidade da intervenção estatal na publicidade de produtos sujeitos à vigilância sanitária.

[Internet]. Revista de Direito Sanitário. São Paulo: v. 12, n. 2 p. 91-111 Jul./Out. 2011. [acesso em 2014 set]. Disponível em:

http://www.revistas.usp.br/rdisan/article/view/13251

3) Vasconcellos A B, Goulart D, Gentil P C, Oliveira T P. A saúde pública e a regulamentação da publicidade de alimentos. [Internet]. Brasília: Ministério da Saúde; [2010?] [acesso em 2014 set]. Disponível em: http://189.28.128.100/nutricao/docs/geral/regulamentaPublicidadeAlimen tos.pdf

4) Agência Nacional de Vigilância Sanitária (Brasil). Resolução de Diretoria Colegiada $\mathrm{n}^{\circ} 24$ de 15 de junho de 2010. Dispõe sobre a oferta, propaganda, publicidade, informação e outras práticas correlatas cujo objetivo seja a divulgação e a promoção comercial de alimentos considerados com quantidades elevadas de açúcar, de gordura saturada, de gordura trans, de sódio, e de bebidas com baixo teor nutricional, nos termos desta Resolução, e dá outras providências. [Internet]. Diário Oficial da União. (2010 jun. 29) [acesso em 2014 set]. Disponível em:

http://portal.anvisa.gov.br/wps/wcm/connect/34565380474597549fd4df3f bc4c6735/RDC24_10_Publicidade+de+alimentos.pdf?MOD=AJPERES

5) Secretaria de Direitos Humanos, Conselho Nacional dos Direitos da Criança e do Adolescente. Resolução n 163, de 13 de março de 2014. Dispõe sobre a abusividade do direcionamento de publicidade e de comunicação mercadológica à criança e ao adolescente. [Internet]. Diário Oficial da União. (2014 abr. 04) [acesso em 2014 set]. Disponível em:

http://pesquisa.in.gov.br/imprensa/jsp/visualiza/index.jsp?jornal=1\&pagin $a=4 \&$ data $=04 / 04 / 2014$

6) Associação Brasileira de Anunciantes. Nota Pública - Publicidade infantil. [Internet]. [2014?] [acesso em 2014 set]. Disponível em: http://www.abert.org.br/web/index.php/notmenu/item/22580-nota-publicapublicidade-infantil

7) Ministério da Saúde (Brasil). Guia Alimentar para a População Brasileira. [Internet]. Brasília: Ministério da Saúde; 2014. 2a ed.[acesso em 2015 
set]. Disponível em:

http://portalsaude.saude.gov.br/images/pdf/2014/novembro/05/GuiaAlimentar-para-a-pop-brasiliera-Miolo-PDF-Internet.pdf

8) OPAS. Organização Pan-Americana da Saúde. Recomendações da consulta de especialistas da Organização Pan-Americana da Saúde sobre a promoção e a publicidade de alimentos e bebidas não alcoólicas para crianças nas Américas. [Internet] Washington DC: Organização Pan-Americana da Saúde; 2012. [acesso em 2014 set]. Disponível em: http://www.paho.org/hq/index.php?option=com_docman\&task=doc_view \&ltemid=270\&gid=17262\&lang $=p t$

9) OPAS. Organização Pan-Americana da Saúde. Plano de Ação para Prevenção da Obesidade em Crianças e Adolescentes. [Internet]. Washington DC: Organização Pan-Americana da Saúde; 2014[acesso em 2015 set]. Disponível em:

http://www.paho.org/bra/images/stories/UTFGCV/planofactionchildobesit y-por.pdf

10)WHO. World Health Organization. Draft Final Report of the Commission on Ending Childhood Obesity. [Internet].Geneva, Switzerland: World Health Organization; 2015. [acesso em 2015 set]. Disponível em: http://www.who.int/end-childhood-obesity/en/

11)ONU. Organização das Nações Unidas. Assembleia Geral, 69ª sessão. Relatório da Relatora especial no campo dos direitos culturais. Documento da Reunião de Peritos. [Internet]. [acesso em 2015 nov]. Nova lorque: Organização das Nações Unidas; 2014. Disponível em: http://daccess-dds-

ny.un.org/doc/UNDOC/GEN/N14/499/88/PDF/N1449988.pdf?OpenElem ent

12) Henriques $P$, Camacho Dias $P$, Burlandy $L$. A regulamentação da propaganda de alimentos no Brasil: convergências e conflitos de interesses. [Internet]. Cad. Saúde Pública, Rio de Janeiro, 30(6): 12191228, jun 2014. [acesso em 2015 jan]. Disponível em:

http://www.scielo.br/scielo.php?pid=S0102-

311X2014000601219\&script=sci_arttext

13)Ministério da Saúde (Brasil), Secretaria de Vigilância em Saúde. Política nacional de promoção da saúde. [Internet]. Brasília: Ministério da Saúde; 2010, $3^{\text {a }}$ ed. [acesso em 2014 set]. Disponível em:

http://bvsms.saude.gov.br/bvs/publicacoes/politica_nacional_promocao_ saude_3ed.pdf

14)Brasil. Decreto $N^{0} 7.272$, de 25 de agosto de 2010. Regulamenta a Lei no 11.346, de 15 de setembro de 2006, que cria o Sistema Nacional de Segurança Alimentar e Nutricional - SISAN com vistas a assegurar o direito humano à alimentação adequada, institui a Política Nacional de Segurança Alimentar e Nutricional - PNSAN, estabelece os parâmetros 
para a elaboração do Plano Nacional de Segurança Alimentar e Nutricional, e dá outras providências. [Internet Diário Oficial da União. (2010 ago. 26) [acesso em 2014 set]. Disponível em: http://www.planalto.gov.br/ccivil_03/_ato20072010/2010/decreto/d7272.htm

15)Ministério da Saúde (Brasil), Secretaria de Atenção à Saúde, Departamento de Atenção Básica. Política Nacional de Alimentação e Nutrição / Ministério da Saúde. Secretaria de Atenção à Saúde. Departamento de Atenção Básica. - Brasília: Ministério da Saúde, 2012.

16)Marins BR, Araújo IS, Jacob SC. A propaganda de alimentos: orientação, ou apenas estímulo ao consumo? [Internet] Ciênc. Saúde Coletiva 2011; 16: 3873-82. [acesso em 2014 set] Disponível em: http://www.scielo.br/scielo.php?pid=S141381232011001000023\&script=sci_arttext

17)Instituto Brasileiro de Defesa do Consumidor - IDEC. Publicidade de alimentos não saudáveis: os entraves e as perspectivas de regulação no Brasil. [Internet] Instituto Brasileiro de Defesa do Consumidor. Cadernos Idec - Série Alimentos - Volume 2. São Paulo: Idec, 2014. [acesso em 2015 nov] Disponível em: http://www.idec.org.br/pdf/publicidadealimentos-nao-saudaveis.pdf

18)Pinheiro ARO, Carvalho MFCC. Transformando o problema da fome em questão alimentar e nutricional: uma crônica desigualdade social. [Internet]. [acesso em 2015 nov] Ciênc. saúde coletiva 2010; 15(1): 121130. Disponível em:

http://www.scielo.br/scielo.php?script=sci_arttext\&pid=S141381232010000100018\&lng=en

19)Cortina A, Martínez, E. Ética. São Paulo: Loyola; 2005.

20)Jonas H. O Princípio Responsabilidade - Ensaio de uma ética para a civilização tecnológica. Rio de Janeiro: PUC Rio; 2006.

21)Segre M, Cohen C. Definição de Valores, Moral, Eticidade e Ética. In: Segre M, Cohen C. (Org.). Bioética. São Paulo: Editora da Universidade de São Paulo; 2002. p. 17-26.

22)Wittgenstein, L. Conferencia sobre Ética. [Internet]. [1929 ou 1930] [acesso em 2014 nov] Disponível em: http://www.ddooss.org/articulos/textos/Wittgenstein_etica.pdf

23)Fisher A. Metaethics: An Introduction. Durham: Acumen; 2011.

24)Muniz E. Publicidade e propaganda origens históricas. [Internet] Caderno Universitário № 148, Canoas: Ed. ULBRA; 2004 [acesso em 2015 nov]. Disponível em: http://www.eloamuniz.com.br/arquivos/1188171156.pdf 
25)Malanga E. Publicidade: uma introdução. São Paulo: Atlas; 1979.

26)Figueiredo AVA. Riscos emergentes dos alimentos: regulação, conflitos e tensões; uma experiência brasileira. [tese] [Internet]. Brasília: Universidade de Brasília; 2014. [acesso em 2015 set]. Disponível em: http://repositorio.unb.br/handle/10482/17746

27)Hawkes C. Marketing de alimentos para crianças: o cenário global das regulamentações. Brasília: Organização Pan-Americana da Saúde/Agência Nacional de Vigilância Sanitária; 2006.

28)Monteiro RA. Influência de aspectos psicossociais e situacionais sobre a escolha alimentar infantil. [tese] [Internet]. Brasília: Universidade de Brasília; 2013. [acesso em 2014 set]. Disponível em: http://repositorio.unb.br/handle/10482/4699

29) Ministério da Saúde (Brasil). Vigilância de fatores de risco e proteção para doenças crônicas por inquérito telefônico - VIGITEL. [Internet] Ministério da Saúde; 2015 [acesso em 2015 set]. Disponível em: http://portalsaude.saude.gov.br/images/pdf/2015/abril/15/PPT-Vigitel2014-.pdf

30) IBGE. Instituto Brasileiro de Geografia e Estatística. Pesquisa de Orçamentos Familiares 2008-2009: antropometria e estado nutricional de crianças, adolescentes e adultos no Brasil. [Internet]. 2010 [acesso em 2014 set]. Rio de Janeiro: Instituto Brasileiro de Geografia e Estatística; 2010. Disponível em:

http://www.ibge.gov.br/home/estatistica/populacao/condicaodevida/pof/2 008_2009_encaa/pof_20082009_encaa.pdf

31)Oliveira ML. Estimativa dos custos da obesidade para o Sistema Único de Saúde do Brasil. [tese] [Internet]. Brasília: Universidade de Brasília; 2013. [acesso em 2014 set]. Disponível em: http://repositorio.unb.br/handle/10482/13323

32) Criança e Consumo. Custo com obesidade no país é de 2,4\% do PIB. [Internet]. 2014 dez [acesso em 2014 set]. Disponível em: http://criancaeconsumo.org.br/noticias/custo-com-obesidade-no-pais-ede-24-do-pib/

33) Conselho Nacional de Autorregulamentação Publicitária - CONAR. Cidadãos responsáveis e consumidores conscientes dependem da informação (e não da falta dela). [Internet]. Agosto de 2012. [acesso em 2014 set]. Disponível em: http://www.conar.org.br/conar-criancas-eadolecentes.pdf

34)Frente pela Regulação da Publicidade de alimentos. Autorregulação da publicidade no Brasil é insuficiente. [Internet]. 2013 set. [acesso em 2014 set]. Disponível em:

http://regulacaoalimentos.blogspot.com.br/2013/09/autorregulacao-dapublicidade-no-brasil.html\#more 
35)Decreto $n^{\circ} 8.552$, de 3 de novembro de 2015.[Internet]. Diário Oficial da União. 2015 nov. 04 [acesso em 2015 dez]. Disponível em:

http://www.planalto.gov.br/ccivil_03/_Ato2015-

2018/2015/Decreto/D8552.htm

36)Lei $n^{0} 11.265$, de 3 de janeiro de 2006. Regulamenta a comercialização de alimentos para lactentes e crianças de primeira infância e também a de produtos de puericultura correlatos. [Internet]. Diário Oficial da União. 2006 jan. 04 [acesso em 2015 dez]. Disponível em:

http://portal.anvisa.gov.br/wps/wcm/connect/dd8746004745968f9e6bde3 fbc4c6735/Lei+N\%C2\%BA+11265.pdf?MOD=AJPERES

37)UNESCO. Organização das Nações Unidas para a Educação, a Ciência e a Cultura. Declaração Universal sobre Bioética e Direitos Humanos. Edição e tradução: Cátedra UNESCO de Bioética da Universidade de Brasília. Brasília, 2005.

38)UNESCO. The Principle of Respect for Human Vulnerability and Personal Integrity. Report of the International Bioethics Committee of UNESCO (IBC). [Internet]. [acesso em 2014 set]. Paris; 2013. Disponível em: http://unesdoc.unesco.org/images/0021/002194/219494E.pdf

39)Beauchamp TL, Childress JF. Principles of Biomedical Ethics. 7th.ed. Oxford University Press, 2012: 90-349.

40)Engelhardt Jr H T. Os princípios da Bioética. In : Fundamentos da Bioética. São Paulo, Loyola, 1998, pp. 131-168.

41)Ministério do Desenvolvimento Social e Combate à Fome (Brasil). Marco de referência de educação alimentar e nutricional para as políticas públicas. - Brasília, DF: MDS; Secretaria Nacional de Segurança Alimentar e Nutricional, 2012.

42)Garrafa V. Bioética. In: Políticas e Sistema de Saúde no Brasil. Giovanella, L et al (orgs.), Cap. 24. $1^{\text {a }}$ ed. Fiocruz e CEBES, 2008:1-17.

43)Nascimento W, Garrafa V. Por uma Vida não Colonizada: diálogo entre bioética de intervenção e colonialidade. [Internet]. Saúde Soc. São Paulo, v.20, n.2, p.287-299, 2011. [acesso em 2015 set]. Disponível em: http://www.scielo.br/pdf/sausoc/v20n2/03.pdf

44)Garrafa V, Porto D. Bioética de intervención. In: Tealdi JC, director. Diccionario latino-americano de bioética. Bogotá: Unesco/Universidad Nacional de Colômbia; 2008. p. 161 - 164.

45)Orlandi EP. Análise de Discurso: princípios e procedimentos. Campinas, SP: Pontes, 2001.

46)Cabrera J. Problemas bioéticos persistentes entre la lógica y la ética: Contribución para un abordaje negativo de la argumentación en Bioética. Premio Anual de Bioética 2014 Fundación Dr. Jaime Roca. [Internet]. 
[acesso em 2016 jan]. Disponível em: http://www.tcba.com.ar/PREMIOBIOETICA/pdf/publicaciones/2014/ganador-bioetica-2014.pdf

47)ANDI Comunicação e Direitos. Menor. In: ANDI Comunicação e Direitos. Glossário. [Internet] [201-?] [acesso em 2015 dez]. Disponível em: http://www.andi.org.br/glossario

48)Dahlet, $P A$. (Re) produzir o inquestionável: nominalização, generalização e naturalização no discurso neoliberal. [Internet]. EID\&A - Revista Eletrônica de Estudos Integrados em Discurso e Argumentação, llhéus, n. 8, p. 206-221, jun.2015. [acesso em 2015 nov]. Disponível em: http://www.uesc.br/revistas/eidea/revistas/revista8/eid\&a_n8_12_patrick. pdf

49)Garrafa V. Ética y política. In: Tealdi JC, director. Diccionario latinoamericano de bioética. Bogotá: Unesco/Universidad Nacional de Colômbia; 2008. p. 531 - 3.

50)Rulli, JE. Globalización y mercado de la alimentación. In: Tealdi JC, director. Diccionario latino-americano de bioética. Bogotá: Unesco/Universidad Nacional de Colômbia; 2008. p. $302-6$.

51)Cortina A. Ética Aplicada y Democracia Radical. $5^{a}$ ed. Madrid: Tecnos; 2008.

52)Dahlet PA. Apagar as divisões, celebrar o consenso: a governança discursiva na era neoliberal. [Internet]. Todas as Letras W, São Paulo, v. 16, n. 1, p. 125-138, maio 2014. [acesso em 2015 nov]. Disponível em: http://editorarevistas.mackenzie.br/index.php/t//article/view/6658/4762

53)Forjaz FM. A ética publicitária e a abusividade da publicidade infantil. [Internet]. Jus Navigandi, Teresina, ano 19, n. 3838, janeiro 2014. [acesso em 2014 set]. Disponível em: http://jus.com.br/artigos/26315/aetica-publicitaria-e-a-abusividade-da-publicidade-infantil\#ixzz3pF5RsVEJ

54)Conselho Nacional de Autorregulamentação Publicitária. Composição do Conselho de Ética do CONAR. [Internet]. [acesso em 2015 out]. Disponível em: http://www.conar.org.br/

55)Mari $\mathrm{H}$. Análise do discurso e ensino: a importância de se repensar o trabalho com a língua. In: Mari H. (Org.) Categorias e práticas de análise do discurso. Belo Horizonte: Núcleo de Análise do Discurso/FALE UFMG; 2000. p.12-22. 


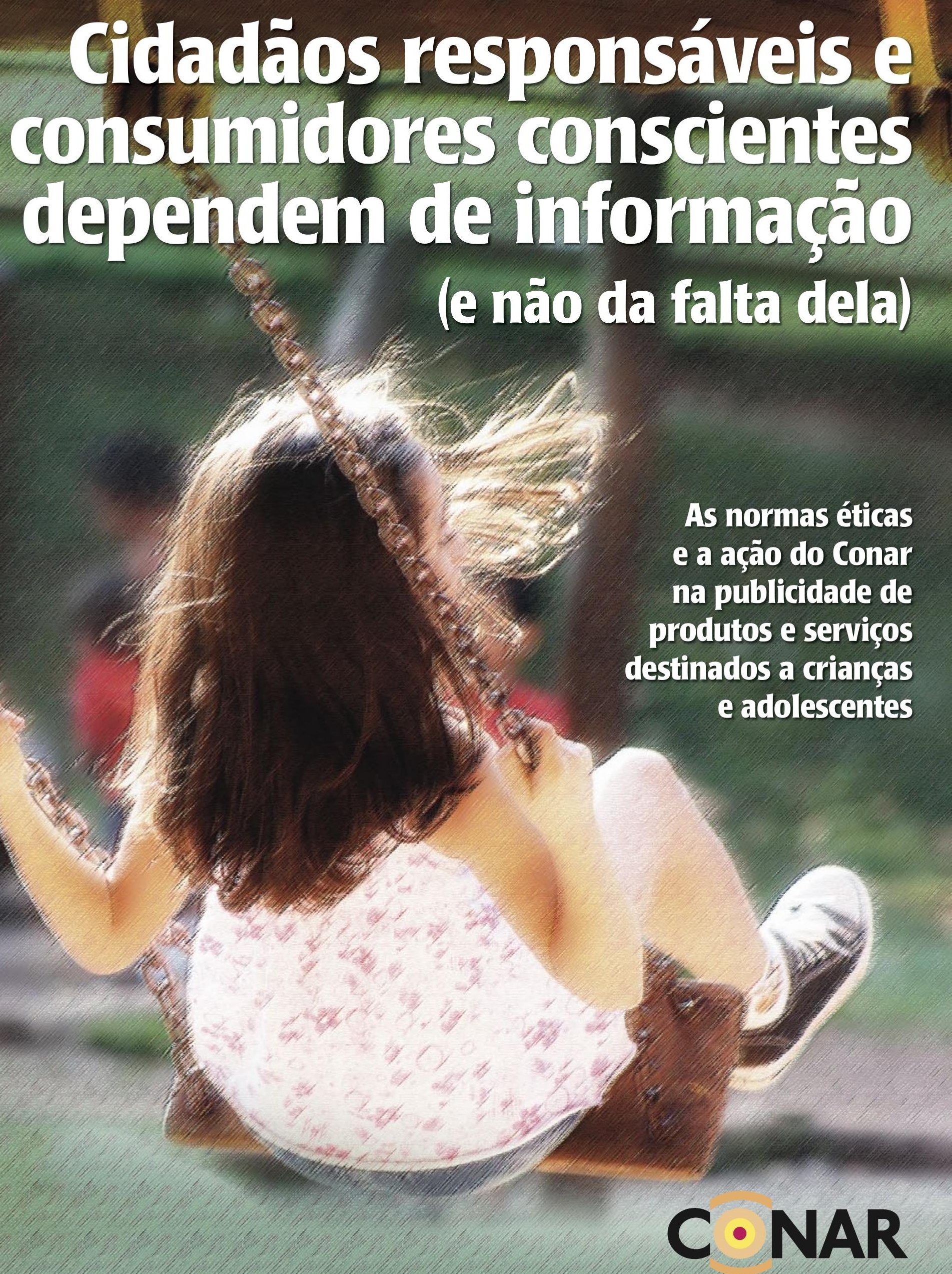

CONSELHO NACIONAL DE AUTORREGULAMENTACÃO PUBUICITÁRIA 
O Conar reflete de forma democrática, ética e técnica os anseios da sociedade em

questões

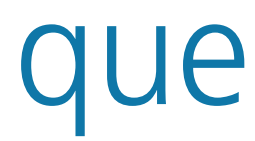

consumo

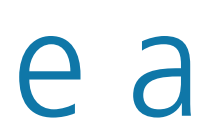

esde 1978, a publicidade brasileira promove e aplica, a partir dos princípios da autorregulamentação e por meio da ação do Conar, recomendações e parâmetros éticos para peças publicitárias de todos os tipos. Foi o Conar, antes que isso preocupasse as autoridades e a sociedade - e antes mesmo da promulgação do Estatuto da Criança e do Adolescente -, o pioneiro no país na imposição de restrições a anúncios de cigarros, bebidas alcoólicas, bem como produtos e serviços destinados a crianças e adolescentes.

Em 2006, essas normas específicas, refletindo a preocupação da sociedade com o tema, passaram por uma completa revisão. Desde então, o Brasil tem uma das mais exigentes regras para publicidade dirigida a menores de idade.

Divulgadas, o Conar tratou de aplicá-la com zelo redobrado. Até maio de 2012, o Conar instaurou e julgou cerca de trezentos processos éticos enquadrados na Seção 11, espaço definido no Código Brasileiro de Autorregulamentação Publicitária para tratar da publicidade de produtos e serviços destinados a crianças e adolescentes, ou em outras partes do Código. Afinal, seus demais dispositivos, a começar pelo artigo $1^{\circ}$ ("Todo anúncio deve ser respeitador e conformar-se às leis do país; deve, ainda, ser honesto e verdadeiro"), seguem perfeitamente válidos para peças destinadas a crianças e adolescentes. Um bom exemplo é o tratamento adotado pelo Código para a publicidade de bebidas alcoólicas, cuja principal preocupação é proteger menores de idade, posto que seu consumo por eles é proibido por lei federal desde os anos 1940.

O número de representações instauradas e julgadas pelo Conar não pode ser considerado especialmente alto, em meio a cerca de 2 mil processos levados ao Conselho de Ética desde $1^{\circ}$ de setembro de 2006, data da entrada em vigor das novas normas, muito menos diante de talvez mais de 500 mil peças publicitárias veiculadas nesse período, numa projeção a partir de números do Ibope Monitor. Pelo contrário, diante de tais números emerge intocado o fato de que a publicidade brasileira é ética de nascença, sendo 0 respeito ao consumidor uma de suas características. Muitos acreditam ser essa a base da excepcional qualidade que projeta a atividade até no exterior, colocando a publicidade brasileira entre as melhores, mais eficientes e premiadas do mundo.

Outra forma de comprovar esse DNA ético da publicidade é estudar os dados do Sistema Nacional de Informações de 


\section{Conar é o pioneiro no país na imposição de restrições a anúncios de todos os tipos, inclusive aqueles de produtos e serviços destinados a crianças e adolescentes}

Defesa do Consumidor, Sindec, do Ministério da Justiça. Segundo esse indicador, em meio a cerca de 140 mil reclamações de consumidores aos Procons de todo o país em doze meses, menos de 1,5\% diz respeito à publicidade. Tão baixo é esse índice que o Sindec sequer o detalha, misturando reclamações contra peças publicitárias veiculadas àquelas, por exemplo, sobre eventuais informações distorcidas fornecidas pelos vendedores aos clientes nos pontos de venda.

As representações julgadas pelo Conar - tanto as de produtos e serviços para menores de idade quanto as demais - podem ser vistas em nosso Boletim de decisões do ConseIho de Ética e no site. A coleção de decisões, além de historiar a ação da autorregulamentação publicitária a serviço da sociedade, expressa a disposição permanente do Conar em refletir da melhor maneira possível, com espírito verdadeiramente democrático, os anseios da sociedade nessa e em outras questões que envolvam o consumo e a publicidade. Expressa também a nossa disposição de defender a liberdade de expressão comercial e a relevância socioeconômica da publicidade para a sociedade contemporânea, porque 0 Conar acredita que cidadãos responsáveis e consumidores conscientes dependem da informação e que a falta dela prejudica-lhes a autonomia e a liberdade de escolha.

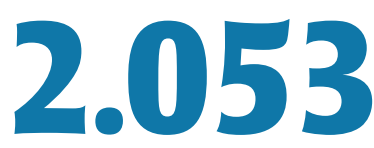

Total de casos abertos pelo Conar entre 1/9/2006 e 31/5/2012

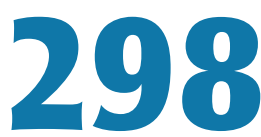

Casos abertos envolvendo publicidade de produtos e serviços para crianças e adolescentes

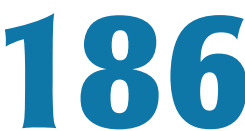

Processos terminaram com penalização do anunciante e sua agência 


\section{A publicidade brasileira é uma atividade que traz a ética em seu DNA}

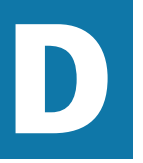

e quem é a responsabilidade pela educação de crianças e adolescentes? Durante muito tempo não havia outra resposta possível: a responsabilidade cabia aos pais e, complementarmente, aos professores, só a eles. Aos poderes públicos reservava-se um distante papel de tutor dos desassistidos e, eventualmente, repressor, confinando menores infratores.

Felizmente, esse entendimento geral mudou. A sociedade brasileira e mundial viu crescer nas últimas décadas uma extraordinária preocupação com a formação e o bem-estar de crianças e adolescentes. Nada mais justificado, nada mais louvável. 0 futuro encerra múltiplos e decisivos desafios para a humanidade, que só poderão ser vencidos se nossos jovens receberem educação formal e social para tanto.

Essa visão se enraizou pela sociedade e chegou a praticamente todas as atividades humanas. Numerosas empresas de todos os portes e setores abraçaram a causa da infância e da educação, enquanto milhões de pessoas passaram a desenvolver trabalhos voluntários direcionados à proteção e à formação de menores, carentes ou não.

A publicidade não poderia ficar indiferente a tal mobilização. Afinal, multiplicou-se nas últimas décadas a relevância dessa atividade, sendo ela a principal base de financiamento da extraordinária aceleração das comunicações no país. Numa hipótese otimista, cerca de 12 milhões de brasileiros recebiam o sinal de TV aberta em suas casas nos anos 1970 (segundo dados do IBGE, havia, em 1970, 4,2 milhões de domicílios com TV no Brasil, um índice de penetração de 24\%). Hoje, são atingidos mais de 187 milhões de brasileiros, os domicílios com TV no país passam de 55 milhões, com um índice de penetração do meio de $97 \%$, segundo dados do Instituto Marplan. Números igualmente extraordinários valem para todos os demais meios de comunicação.

Os publicitários perceberam a relevância da atividade já nos anos 1950, quando cunharam um código de conduta profissional, incorporado, em 1965, à legislação que rege a publicidade. Estava lançada a semente que veio germinar em 1978, com a publicação do Código Brasileiro de Autorregulamentação Publicitária que, por sua vez, deu origem ao Conar, Conselho Nacional de Autorregulamentação Publicitária.

0 Código e o Conar dotaram a publicidade de um instrumento prático, simples e rápido para interagir com a sociedade, respeitando-a e ouvindo-a a um só tempo, já que definiuse ali um canal de comunicação altamente eficiente para que 


\section{Código e 0 \\ Conar dotaram \\ a publicidade de \\ um instrumento \\ prático, simples \\ e rápido para \\ interagir com \\ a sociedade, respeitando-a e ouvindo-a \\ a um só tempo}

qualquer pessoa pudesse manifestar sua opinião e eventual desagrado com o conteúdo da mensagem publicitária. Com o Conar, um único consumidor pode alterar ou mesmo deter a maior campanha publicitária em exibição. Uma queixa, ainda que manuscrita e lavrada em termos humildes, pode confrontar um investimento de milhões de reais.

O segredo de compartilhar tanto poder com o consumidor sem paralisar e oprimir a atividade está no teor do Código Ético-Publicitário, que soube detalhar restrições sem asfixiar a natural e desejável criatividade dos profissionais do setor e, talvez, o mais importante: ter a capacidade de se renovar permanentemente. Nos últimos dez anos, o Código Brasileiro de Autorregulamentação Publicitária passou por quatro reformas marcantes, envolvendo publicidade de bebidas alcoólicas; alimentos, produtos e serviços destinados a crianças e adolescentes e sustentabilidade.

Essas reformas se deram após um processo de amadurecimento e discussão de cada tema com numerosos interlocutores, inclusive autoridades e os elos do mercado publicitário. Definidas, as normas entram em vigor já em consenso com o mercado e sem nenhum ônus para o governo, em todas as suas instâncias.

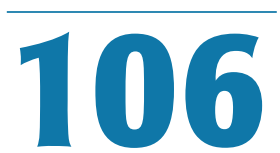

Casos abertos pelo Conar envolveram apelo imperativo de consumo

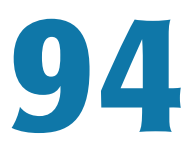

Destes casos foram abertos por iniciativa própria

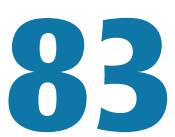

Casos terminaram com penalização para 0 anunciante e sua agência 
O sistema misto

de legislação e

autorregulamentação provê

\section{a segurança que}

convém ao consumidor

\section{C}

onvicção número um do Conar: as leis vigentes no Brasil mais a autorregulamentação garantem integralmente o consumidor contra eventuais abusos da publicidade. Nunca é demais lembrar que o Código de Defesa do Consumidor prevê a pena de prisão para o anunciante que levar o consumidor a engano.

Outra forte convicção do Conar: a publicidade é importante para o progresso da sociedade. Numerosos estudos comprovam a força da publicidade como motor de mercados, de qualidade de vida, de crescimento material e humano. As pessoas consomem melhor com informação. 0 processo de consumo começa, normalmente, nos meios de comunicação, com a oferta de novidades, vantagens, especificações, preços, descontos, parcelamentos, brindes etc., que geram facilidades, comodidades, conforto, segurança etc. Publicidade é sinônimo de concorrência, e concorrência é garantia de melhores condições para o consumidor. Sem a publicidade, a velocidade e a qualidade do consumo caem drasticamente, bem como os índices de crescimento da economia.

A motivação do Conar em defesa da publicidade livre e ética apenas sublinha a necessidade absoluta de sintonia entre o Código Brasileiro de Autorregulamentação Publicitária e os anseios da sociedade. $E$ isso nos leva às normas éticas para proteger crianças e adolescentes.

\section{UM AMPLO DEBATE COM A SOCIEDADE}

Em 19 de abril de 2004 instalou-se um grupo de trabalho envolvendo as entidades fundadoras do Conar - ABA, Abap, Abert, Aner, ANJ e Central de Outdoor - com apoio técnico de associações setoriais. As demandas de autoridades, organizações, imprensa etc. foram levantadas e mediadas com as entidades representativas de indústria, comércio e prestadores de serviços voltados para crianças e adolescentes. Instâncias governamentais e não governamentais participaram das

\section{A publicidade é importante para o progresso da sociedade. Numerosos estudos comprovam de crescimento material e humano.}




\section{As pessoas \\ consomem \\ melhor com \\ informação. \\ 0 processo de \\ consumo começa, normalmente, nos meios de comunicação}

discussões, da mesma forma que representantes do Conar estiveram presentes a diversas audiências públicas, seminários e debates. Um vigoroso mapeamento das experiências internacionais na matéria ajudou a definir rumos e soluções.

Assim, em $1^{\circ}$ de setembro de 2006 entraram em vigor novas normas éticas que atualizaram a Seção 11 do Código Brasileiro de Autorregulamentação Publicitária e seu Anexo $H$, que trata da publicidade de alimentos e bebidas não alcoólicas. Para bebidas alcoólicas, o Conar já havia produzido novas normas em 2003, que foram aperfeiçoadas em 2008, também visando prioritariamente a proteção do público menor de idade.

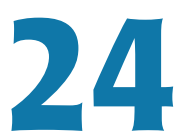

Casos abertos pelo Conar envolveram consumo responsável

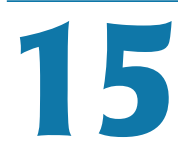

Destes casos foram abertos mediante queixa de consumidor

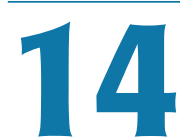

Casos terminaram com penalização para 0 anunciante e sua agência

a força da publicidade como motor de mercados, de qualidade de vida, 


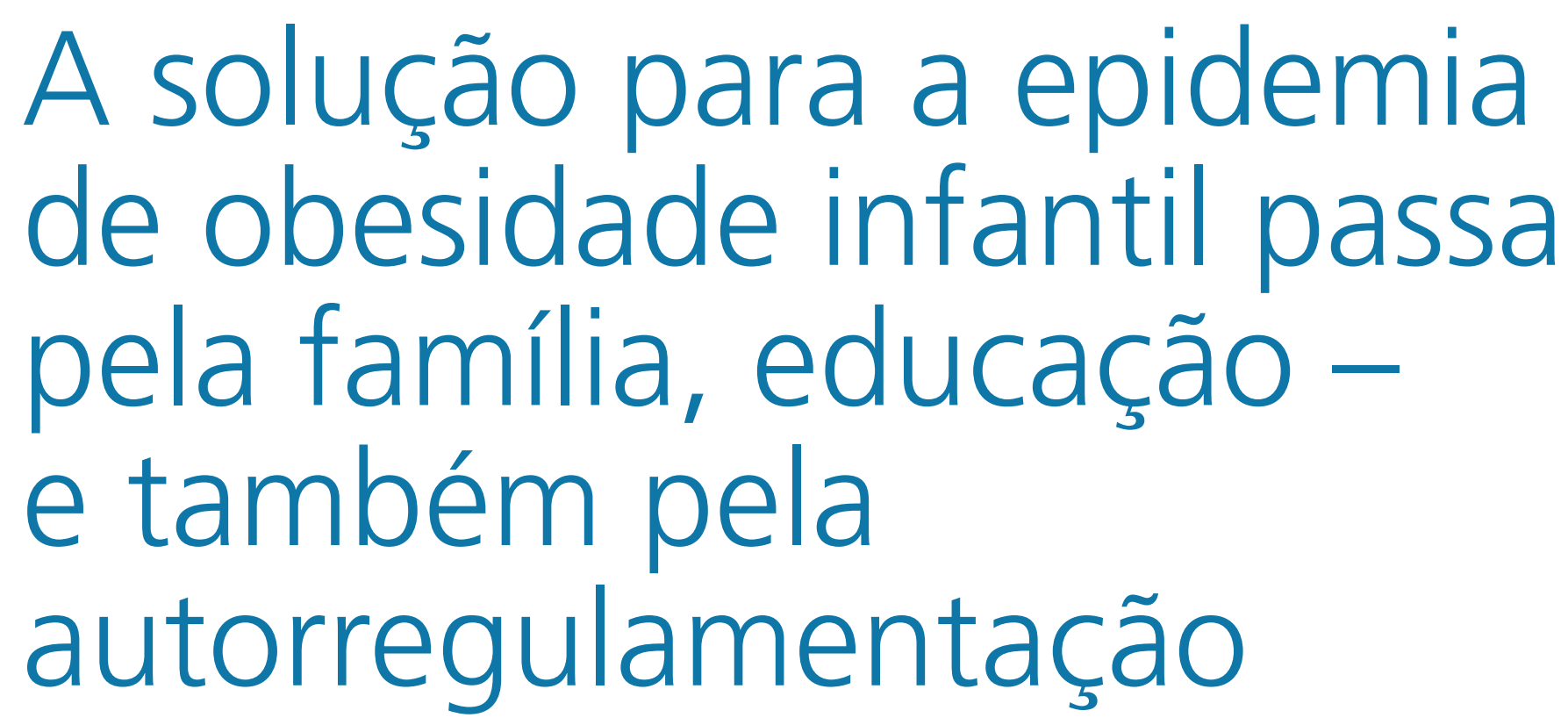

$\mathbf{A}$ vançam as discussões sobre os impactos da epidemia de obesidade que afeta o mundo, atingindo indiscriminadamente jovens, adultos e crianças. Cada vez mais, as origens múltiplas e entrecruzadas deste gravíssimo problema são mapeadas e entendidas. Cristaliza-se a conclusão de que se trata de problema complexo com origem em múltiplos fatores. 0 estudo inglês Foresight Report, por exemplo, aponta mais de cem fatores que influenciam direta ou indiretamente a questão, sendo a publicidade apenas um deles.

No entanto, para muitos, anúncios de alimentos e refrigerantes tornaram-se vilões que precisam ser banidos com a maior brevidade possível e sem maiores discussões, como se essa medida fosse capaz de acabar com a obesidade. Esta tese não está prosperando. Apenas dois países no mundo - Suécia e Noruega - impuseram limitações legais à publicidade de produtos e serviços dirigidos a crianças e adolescentes. Também a província de Quebec, no Canadá, baniu a publicidade do gênero. Ou seja, apenas 0,32\% da população da Terra é, hoje, privada de acessar informações publicitárias sobre alimentos e refrigerantes. Em contrapartida, a China, depois de discutir longamente a questão, adotou a autorregulamentação para a publicidade.

Os resultados observados em Quebec mostram de forma clara que banir a publicidade não é solução para nada. Em 2004, quase 25 anos depois de adotada a proibição da publicidade, os índices de obesidade infantil são praticamente idênticos aos das demais províncias do país, como atestado pela autoridade sanitária local. Pior: os indicadores de sobrepeso e obesidade registrados em crianças de Quebec são superiores aos observados na província da vizinha Alberta, onde a publicidade não sofreu restrições. Estudo em profundidade da experiência de Quebec, promovido pelo Journal of Marketing Research, mostra que o banimento da publicidade teria inibido o consumo diário de menos de quatro calorias por criança - o equivalente a trinta segundos de caminhada - em relação às demais regiões do país.

Certamente influenciados pela falta de resultados da experiência de Quebec, autoridades da Europa e dos Estados Unidos reafirmaram recentemente o propósito de evitar legislação restritiva para a publicidade do gênero, optando por reforçar as instâncias da educação e da autoridade da família, complementados por mecanismos de autorregulamentação associados às plataformas de cooperação voluntária dos anunciantes, os chamados pledges, já adotados pelas principais empresas do setor e postos em prática em vários países, inclusive no Brasil.

É essa a posição mais recente do Parlamento europeu, 


\section{Parlamento europeu rejeitou formalmente a proibição de publicidade para crianças em outubro de 2011 e de novo em abril de 2012}

que rejeitou formalmente a proibição de publicidade para crianças em outubro de 2011 e de novo em abril de 2012. No âmbito do governo europeu, o comissário de Saúde e Proteção ao Consumidor declarou, em março, que restrições não são necessárias, na medida em que a indústria está comprometida com a publicidade responsável.

Nos Estados Unidos, há dois grupos trabalhando sobre o tema. 0 da Casa Branca, liderado pela primeira-dama Michelle Obama, vem discutindo a questão com as empresas de alimentos e mídia, buscando soluções de consenso. Já o Congresso acolheu recomendação de uma comissão formada por representantes de quatro agências governamentais - Center of Disease Control and Prevention, Federal Trade Comission, Food and Drug Administration e Department of Agriculture -, que considerou desnecessárias leis contra a publicidade.

A Organização Mundial da Saúde, por sua vez, não emitiu diretiva propondo o banimento da publicidade de alimentos e refrigerantes ou de restrições a ela como política pública, preferindo propor recomendações gerais a serem adotadas pelos seus Estados-membros, frisando a necessidade de uma abordagem multidisciplinar. A posição atual da OMS é no sentido de mobilizar todos os inúmeros agentes com influência para a solução do problema.

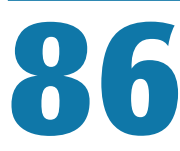

Casos abertos pelo Conar envolveram denúncia de comportamento perigoso ou deseducativo

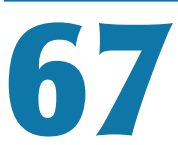

Destes casos foram abertos mediante queixa de consumidor

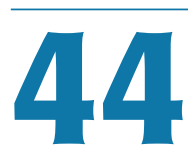

Casos terminaram com penalização para o anunciante e sua agência 


\section{Uma breve \\ história do Conar}

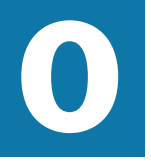

Código Brasileiro de Autorregulamentação Publicitária e o Conar nasceram de uma ameaça à atividade: no final dos anos 1970, o governo federal pensava em sancionar uma lei criando uma espécie de censura prévia à propaganda. Diante dessa ameaça, uma resposta inspirada: autorregulamentação, sintetizada num Código, que teria o propósito de zelar pela liberdade de expressão comercial e defender os interesses das partes envolvidas no mercado publicitário, inclusive os do consumidor.

A ideia foi um sucesso. Num espaço de poucos meses, anunciantes, agências e veículos subordinaram seus interesses comerciais e criativos ao Código, solenemente entronizado durante o III Congresso Brasileiro de Propaganda, em 1978. Nunca mais o abandonariam.

Logo em seguida era fundado o Conar, uma ONG encarregada de fazer valer o Código. Desde então, já foram instaurados quase 8 mil processos éticos e foi promovido um sem-número de reuniões de conciliações entre associados em conflito. As decisões do Conar nunca foram desrespeitadas. Nas raras vezes em que foram questionadas na Justiça, o Conar saiu-se vitorioso.

\section{O Conar foi fundado pelas entidades representativas do mercado publicitário:}

- ABA - Associação Brasileira de Anunciantes

- ABAP - Associação Brasileira de Agências de Propaganda

- ABERT - Associação Brasileira de Emissoras de Rádio e Televisão

- ANER - Associação Nacional de Editores de Revistas

- ANJ - Associação Nacional de Jornais

- Central de Outdoor

Aderiram ao Conar:

- ABTA - Associação Brasileira de Televisão por Assinatura

- IAB Brasil - Interactive Advertising Bureau

- FENEEC - Federação Nacional das Empresas

Exibidoras Cinematográficas

\section{Conar é capaz de adotar medida liminar de sustação no intervalo de algumas horas a partir}




\section{Como funciona o Conar}

O Conar tem sede em São Paulo, conta com cerca de vinte funcionários que trabalham em período integral e é mantido pela contribuição das cerca de quatrocentas empresas a ele associadas.

\section{Os preceitos que definem a ética publicitária são:}

- todo anúncio deve ser honesto e verdadeiro, bem como respeitar as leis do país;

- deve ser preparado com o devido senso de responsabilidade social;

- deve ter presente a responsabilidade da cadeia de produção junto ao consumidor;

- deve respeitar o princípio da leal concorrência;

- deve respeitar a atividade publicitária.

São atendidas denúncias de consumidores, autoridades, empresas associadas ou formuladas pela própria diretoria. Feita a denúncia, o Conselho de Ética do Conar - o órgão soberano na fiscalização, julgamento e deliberação no que se relaciona à obediência e cumprimento do Código - se reúne e delibera, garantindo amplo direito de defesa ao anunciante e sua agência. Se a denúncia tiver procedência, o Conar recomenda aos veículos que seja suspensa a exibição da peça ou sugere correções. Pode ainda advertir anunciante e agência.

O Conselho de Ética está dividido em oito Câmaras, sediadas em São Paulo, Rio, Brasília, Porto Alegre e Recife, e é formado por 180 conselheiros, entre representantes da sociedade civil - pessoas que se destacaram na defesa do consumidor ou no estudo das relações de consumo - e publicitários. Todos trabalham para o Conar em regime voluntário.

O Conar não exerce em nenhuma hipótese censura prévia. Anúncios que porventura contenham infração flagrante ao Código têm sua sustação recomendada de forma liminar aos veículos de comunicação. 0 Conar é capaz de adotar medida liminar de sustação no intervalo de algumas horas a partir do momento em que toma conhecimento da denúncia.

\section{As decisões}

do Conar

nunca foram

desrespeitadas.

Nas raras vezes

em que foram

questionadas na

Justiça, o Conar

saiu-se vitorioso

\section{6}

Casos abertos pelo Conar envolveram os demais questionamentos previstos na Seção 11 do Código

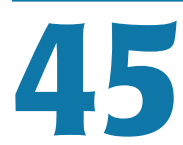

Destes casos foram abertos mediante queixa de consumidor

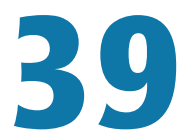

Casos terminaram com penalização para o anunciante e sua agência 


\section{A íntegra da Seção 11 do Código Ético-Publicitário}

Artigo 37 - Os esforços de pais, educadores, autoridades e da comunidade devem encontrar na publicidade fator coadjuvante na formação de cidadãos responsáveis e consumidores conscientes. Diante de tal perspectiva, nenhum anúncio dirigirá apelo imperativo de consumo diretamente à criança. E mais:

1 - Os anúncios deverão refletir cuidados especiais em relação a segurança e às boas maneiras e, ainda, abster-se de:

a. desmerecer valores sociais positivos, tais como, entre outros, amizade, urbanidade, honestidade, justiça, generosidade e respeito a pessoas, animais e ao meio ambiente;

b. provocar deliberadamente qualquer tipo de discriminação, em particular daqueles que, por qualquer motivo, não sejam consumidores do produto;

c. associar crianças e adolescentes a situações incompatíveis com sua condição, sejam elas ilegais, perigosas ou socialmente condenáveis;

d. impor a noção de que o consumo do produto proporcione superioridade ou, na sua falta, a inferioridade;

e. provocar situações de constrangimento aos pais ou responsáveis, ou molestar terceiros, com o propósito de impingir o consumo; f. empregar crianças e adolescentes como modelos para vocalizar apelo direto, recomendação ou sugestão de uso ou consumo, admitida, entretanto, a participação deles nas demonstrações pertinentes de serviço ou produto;

g. utilizar formato jornalístico, a fim de evitar que anúncio seja confundido com notícia;

h. apregoar que produto destinado ao consumo por crianças e adolescentes contenha características peculiares que, na verdade, são encontradas em todos os similares;

i. utilizar situações de pressão psicológica ou violência que sejam capazes de infundir medo.

2 - Quando os produtos forem destinados ao consumo por crianças e adolescentes, seus anúncios deverão:

a. procurar contribuir para o desenvolvimento positivo das relações entre pais e filhos, alunos e professores, e demais relacionamentos que envolvam o público-alvo;

b. respeitar a dignidade, ingenuidade, credulidade, inexperiência e o sentimento de lealdade do público-alvo;

c. dar atenção especial às características psicológicas do público-alvo, presumida sua menor capacidade de discernimento;

\section{Conheça a íntegra do Código Brasileiro de Autorregulamentação Publicitária no site do Conar}


d. obedecer a cuidados tais que evitem eventuais distorções psicológicas nos modelos publicitários e no público-alvo;

e. abster-se de estimular comportamentos socialmente condenáveis.

\section{Parágrafo $\mathbf{1}^{\circ}$}

Crianças e adolescentes não deverão figurar como modelos publicitários em anúncio que promova o consumo de quaisquer bens e serviços incompatíveis com sua condição, tais como armas de fogo, bebidas alcoólicas, cigarros, fogos de artifício e loterias, e todos os demais igualmente afetados por restrição legal.

\section{Parágrafo $2^{\circ}$}

0 planejamento de mídia dos anúncios de produtos de que trata o inciso 2 levará em conta que crianças e adolescentes têm sua atenção especialmente despertada para eles. Assim, tais anúncios refletirão as restrições técnica e eticamente recomendáveis e adotar-se-á a interpretação a mais restritiva para todas as normas aqui dispostas.

Nota: Nesta Seção adotaram-se os parâmetros definidos no art. $2^{\circ}$ do Estatuto da Criança e do Adolescente (Lei $n^{\circ}$ 8.069/90): "Considera-se criança, para os efeitos desta Lei, a pessoa até doze anos de idade". 
As campanhas processadas

Veja nesta e nas páginas seguintes, a relação completa de processos abertos pelo Conar entre $1^{0}$ de setembro de 2006 e 31 de maio de 2012, envolvendo campanhas e peças publicitárias que, de alguma maneira, envolvem publicidade voltada a ou que tangenciam crianças e adolescentes. Para uma descrição detalhada de cada um desses processos, visite o site do Conar: www.conar.org.br.

\section{USO ANTIÉTICO DAS FERRAMENTAS PUBLICITÁRIAS}

\section{APELO IMPERATIVO DE CONSUMO}

\section{"A hora mais divertida do dia tem sempre Ana Maria" \\ Representação nº 433/08, julgada em fevereiro de 2009 \\ Anunciante: Grupo Bimbo}

\section{"Ades Nutrikids"}

Representação n 266/09, em recurso extraordinário, julgada em junho de 2010

Anunciante: Unilever Brasil

\section{"Beach Park"}

Representação $n^{0}$ 006/10, julgada em março de 2010

Anunciante e agência: Beach Park Hotéis e Turismo e Verve Comunicação

\section{"Betakids"}

Representação nº 14/08, julgada em março de 2008

Anunciante: Laticínios Betânia

\section{"Big Quiz Chaves"}

Representação nº 052/09, julgada em março de 2009

Anunciante: SBT

"Biotônico Fontoura - Mamãe, eu quero Biotônico" Representação n 233/06, julgada em novembro de 2006

Anunciante: DM Indústria Farmacêutica

\section{"Bob's - Trikids"}

Representação n 345/08, julgada em março de 2009

Anunciante: Bob's

\section{"Boneco Titanium - Brincando com você"}

Representação n² 212/07, em recurso ordinário, julgada em novembro de 2007 Anunciante: Vipeplas Brinquedos

\section{"Brinca Mundi Parque Infantil"}

Representação n0 025/10, julgada em março de 2010

Anunciante e agência: MF Silva e Comunix Comunicação

\section{"Brinquedos Rosita - Piratas do Caribe"}

Representação n 173/07, julgada em setembro de 2007

Anunciante e agência: Brinquedos Rosita e Frevo Filmes

\section{"Cacau Show - Chocobichos"}

Representação n 244/11, julgada em dezembro de 2011

Anunciante e agência: Cacau Show e In Rio

\section{"Calesita"}

Representação nº 006/09, julgada em abril de 2009

Anunciante: Calesita Indústria de Brinquedos

"Candide Indústria e Comércio - Battle Machines"

Representação nº 002/10, julgada em maio de 2010

Anunciante: Candide Indústria e Comércio

"Casa \& Vídeo - Vem brincar com a gente" Representação n 289/09, julgada em novembro de 2009 Anunciante: Lojas Casa \& Vídeo

"Casas Pernambucanas - Hoje eu quero a loja inteira" Representação no 109/09, julgada em julho de 2009 Anunciante e agência: Casas Pernambucanas e Lew'Lara

\section{"Chocolate Baton Garoto - Acampamento"}

Representação n 206/06, julgada em outubro de 2006

Anunciante e agência: Chocolates Garoto e W/Brasil

\section{"Colecione Playmobil"}

Representação n 350/08, julgada em março de 2009

Anunciante: Sunny Brinquedos

\section{"Danoninho Ice"}

Representação n 290/09, julgada em março de 2010

Anunciante e agência: Danone e Young \& Rubicam

\section{"Delazari Entretenimentos - Cia do Lazer"}

Representação nº 069/10, julgada em maio de 2010

Anunciante: Delazari Entretenimentos

\section{"Delícia - É mais que bom"}

Representação n 267/07, julgada em dezembro de 2007

Anunciante e agência: Bunge Brasil e Lew Lara Propaganda

“Depois de tomar Mini Schin, a brincadeira continua. Junte as garrafinhas e jogue boliche com os amigos"

Representação n 332/09, julgada em maio de 2010

Anunciante e agência: Primo Schincariol e Lew Lara 


\section{"Dia das Crianças C 8 A"}

Representação n 252/09, julgada em novembro de 2009

Anunciante: C\&A Modas

\section{“Dia das Crianças Riachuelo 2011"}

Representação n² 219/11, julgada em outubro de 2011

Anunciante: Lojas Riachuelo

\section{"Dia das Crianças Riachuelo"}

Representação nº 298/10, julgada em março de 2011

Anunciante: Lojas Riachuelo

\section{"Dia dos Fuzarkas Renner"}

Representação n 278/09, julgada em dezembro de 2009

Anunciante: Lojas Renner

\section{"Dia dos Fuzarkas Renner"}

Representação n² 295/10, em recurso ordinário, julgada em maio de 2011

Anunciante: Lojas Renner

\section{"Dia dos Pais Esplanada Shopping"}

Representação n 298/08, julgada em dezembro de 2008

Anunciante e agência: Associação dos Lojistas do Esplanada Shopping Center e CA

Comunicação

\section{"Dolly Guaraná"}

Representação nº 343/09, julgada em outubro de 2010

Anunciante: Dettal Part Participações, Importação, Exportação e Comércio

\section{"Dr. Oetker - Promoção Zoobremesas"}

Representação n 402/08, julgada em maio de 2009

Anunciante: Dr. Oetker Brasil

\section{"DTC Trading Company - Amigos fedorentos"}

Representação no 133/10, julgada em julho de 2010

Anunciante: DTC Trading Company

\section{"Esposende. Sapato + presente, emocão em dobro"}

Representação n⿳0 381/08, julgada em dezembro de 2008

Anunciante: Esposende Calçados

\section{"Estrela - Flower Surprise"}

Representação n 241/11, julgada em março de 2012

Anunciante: Manufatura de Brinquedos Estrela

“Estrela - Promoção Comprou, ganhou”

Representação no 196/09, julgada em setembro de 2009

Anunciante: Manufatura de Brinquedos Estrela

\section{"Estrelitas"}

Representação no 140/09, em recurso ordinário, julgada em novembro de 2009

Anunciante: Nestlé

\section{"Eu quero um quarto com a minha cara"}

Representação n 035/08, em recurso ordinário, julgada em agosto de 2008

Anunciante: Editora Escala

\section{"Experimente Mabelokos. 0 biscoito sem gordura trans mais gostoso do} planeta"

Representação n 300/08, julgada em setembro de 2008

Anunciante: Cipa

\section{"Extraordinário mundo Joy"}

Representação nº 025/12, julgada em abril de 2012

Anunciante: Grupo Morena Rosa - Joy

\section{"Fazenda do Shopping Cidade"}

Representação n 241/08, julgada em setembro de 2008

Anunciante e agência: Cityshop e Elétrica

"Férias Turma da Mônica no Playcenter"

Representação nº 163/11, julgada em setembro de 2011

Anunciante: Playcenter

\section{"Ferrero do Brasil - Nutella Shrek"}

Representação n 195/10, julgada em setembro de 2010

Anunciante: Ferrero do Brasil

"Filhote Mania - DTC"

Representação nº 099/10, julgada em julho de 2010

Anunciante: DTC Trading Company

\section{"Filhotes Mania - DTC"}

Representação nº 099/10, julgada em maio de 2010

Anunciante: DTC Trading

\section{"Giraffas - Gira pintura"}

Representação n 240/11, julgada em maio de 2012

Anunciante: Lanchonetes Giraffas

\section{"Glossy Girls by Vulteen"}

Representação nº 334/09, julgada em maio de 2010

Anunciante: Vult Comércio de Cosméticos

\section{"Grendene - Nova Sandália da Barbie"}

Representação n 340/09, julgada em março de 2010

Anunciante: Grendene Sobral

\section{"Grow Jogos e Brinquedos - Quero Super Trunfo"}

Representação n 131/10, em recurso ordinário, julgada em setembro de 2010 Autora: Conar, por iniciativa própria

\section{"Hasbro - Furreal Friends"}

Representação n 003/10, julgada em março de 2010

Anunciante: Hasbro Brasil

"Hasbro Brasil - Simon Trickster"

Representação nº 284/09, julgada em maio de 2010

Anunciante: Hasbro

\section{“Havaianas - Princesa”}

Representação n 304/11, julgada em março de 2012

Anunciante e agência: São Paulo Alpargatas e AlmapBBDO

\section{"Homeplay brincando com você"}

Representação nº 010/08, julgada em março de 2008

Anunciante: Vipeplas Brinquedos e Utilidades

\section{"Hopi Hari - Alice no País das Maravilhas"}

Representação nº 005/10, julgada em março de 2010

Anunciante e agência: Hopi Hari e NBS

“Horton e o Mundo dos Quem! Peça já o seu...” Representação n 368/08, julgada em novembro de 2008 Anunciante: Fox Film

\section{"Hot Wheels - Hot Cards"}

Representação n 360/08, em recurso ordinário, julgada em maio de 2009 Anunciante: Mattel do Brasil 
"Instrumentos musicais da Xuxa - Candide"

Representação n 268/09, julgada em novembro de 2009

Anunciante: Candide Indústria e Comércio

\section{"International Shopping"}

Representação nº 342/09, julgada em maio de 2010

Anunciante: Internacional Guarulhos Shopping Center

\section{"Kamen Rider Dragon Knight - Long Jump"}

Representação n 317/09, em recurso ordinário, julgada em maio de 2010

Anunciante e agência: Long Jump e Frevo

“Kidy + brinquedo $=$ presentão de Dia das Crianças"

Representação n 366/08, julgada em dezembro de 2008

Anunciante: Kidy Birigui

\section{"Kidy. 100\% saúde"}

Representação n 303/08, julgada em novembro de 2008

Anunciante: Kidy Birigui Calçados

\section{"Klin"}

Representação n² 201/09, julgada em novembro de 2009

Anunciante: Klin Produtos Infantis

"Leve a turminha para sua festa"

Representação n 301/08, julgada em novembro de 2008

Anunciante e agência: Cromus Embalagens e Mauricio de Sousa Produções

\section{"Mais diversão na hora do lanche"}

Representação n 236/10, em recurso ordinário, julgada em março de 2011

Anunciantes: Porcelana Panger e Maurício de Sousa Produções

\section{"Mattel - Mega Feirinha Hot"}

Representação nº 026/09, julgada em março de 2009

Anunciante: Mattel do Brasil

\section{"Mc Lanche Feliz - Avatar"}

Representação n 337/09, julgada em junho de 2010

Anunciante e agência: McDonald's e Taterka

\section{"Milium - Natal 2012"}

Representação nº 004/12, julgada em abril de 2012

Anunciante e agência: Comercial de Ferragens Milium e Onewg Multicomunicação

\section{"Mini Chef Sorveteira"}

Representação n 251/11, julgada em março de 2012

Anunciante: Long Jump

\section{"Mochila Hot Wheels"}

Representação nº 035/09, julgada em julho de 2009

Anunciante: Sestini Mercantil

\section{"Mundo Irado Pernambucanas"}

Representação n 229/09, julgada em novembro de 2011

Anunciante e agência: Casas Pernambucanas e J. Walter Thompson

\section{"Natal divertido Backyardigans no Raposo Shopping"}

Representação n 308/11, julgada em março de 2012

Anunciante e agência:Raposo Shopping e Confraria Visuale

"Natal do Shopping Metrô Tatuapé"

Representação n 436/08, julgada em julho de 2009

Anunciante: Shopping Metrô Tatuapé

\section{“Nestlé - Galera animal"}

Representação nº 358/10, julgada em maio de 2011

Anunciante e agência: Nestlé e W/McCann

"Nickelodeon Brasil - Atenção galera" e "Nickelodeon Brasil - envie a palavra Bob"

Representações nº 029/09 e 030/09, julgadas em março de 2009

Anunciante: Nickelodeon Brasil

"Novo Polenguinho Super - Com sabor de diversão"

Representação n 204/06, julgada em outubro de 2006

Anunciante e agência: Grupo Polenghi e Famiglia Publicidade

\section{"Novos Bolinhos Bauducco"}

Representação nº 242/11, em recurso ordinário, julgada em maio de 2012 Anunciante e agência: Pandurata e AlmapBBDO

\section{"O mundo da Xuxa"}

Representação n 297/08, julgada em setembro de 2008

Anunciante: Xuxa Promoções e Produções Artísticas

\section{"Papatenis do Guga”}

Representação n 260/09, julgada em dezembro de 2009

Anunciante: Grendene Sobral

\section{"Princesas - Grendene"}

Representação n² 254/09, julgada em dezembro de 2009

Anunciante: Grendene Sobral

\section{"Promoção Amigo Genial Chamyto"}

Representação no 141/09, julgada em julho de 2009

Anunciante: Nestlé

\section{"Promoção Bubbaloo Futebol Clube"}

Representação no 161/10, julgada em setembro de 2010

Anunciante e agência: Cadbury Brasil e WMcCann

\section{"Promoção Mickey Mania"}

Representação n 372/08, julgada em setembro de 2009

Anunciante: The Walt Disney Company (Brasil)

\section{“Queremos Tip-Top”}

Representação nº 319/11, julgada em maio de 2012

Anunciante: TDB Textil David Bobrow

"Rádio e Televisão Bandeirantes - Envie Kids para 48069"

Representação n 117/10, julgada em setembro de 2010

Anunciante: Rádio e Televisão Bandeirantes

\section{"Ri Happy - Orgulho de brincar"}

Representação no 145/10, julgada em setembro de 2010 Anunciante: Ri Happy Brinquedos

\section{"Ri Happy - Relógio do Solzinho"}

Representação n 305/11, julgada em março de 2012

Anunciante: Ri Happy

"Rubik's é a nova sensação do momento" Representação nº 050/08, julgada em julho de 2008

Anunciante: Bungee Brasil

\section{"Sandália Hello Kitty - Grendene"}

Representação n 253/09, julgada em dezembro de 2009

Anunciante: Grendene Sobral 


\section{"Sandália Moranguinho"}

Representação n 330/07, julgada em abril de 2008

Autor: Grupo de consumidores (Instituto Alana)

\section{"Sapo Xulé"}

Representação nº 037/09, julgada em março de 2009

Anunciante: Total Spin Brasil Serviços de Telecomunicações

\section{"SBT - Rebeka - Carrossel animado"}

Representação n 288/09, julgada em maio de 2010

Anunciante: SBT

“Shopping Metrô Tatuapé e Turner - ... E não perca a promoção mochilas Cartoon..."

Representação n 434/08, julgada em março de 2009

Anunciantes: Shopping Metrô Tatuapé e Turner International

\section{"Sorvete Mágico - By Kids Conthey"}

Representação n 279/09, julgada em dezembro de 2009

Anunciante: Conthey

"Spuleta - Biscoito tão gostoso quanto uma boa aventura" Representação n 255/09, julgada em maio de 2010

Anunciante: Dunga Produtos Alimentícios

"Star Desenhos Animados - 0 grilo feliz"

Representação nº 027/09, julgada em março de 2009

Anunciante: Start Desenhos Animados

\section{"Sunny Brinquedos - Neopets"}

Representação n 007/09, julgada em maio de 2009

Anunciante: Sunny Brinquedos

\section{"Super Trunfo - Eu quero todos"}

Representação nº 301/10, julgada em maio de 2011

Anunciante: Grow

"Tem coisas que você vai ter só quando for adulto..."

Representação n 200/11, julgada em setembro de 2011

Anunciante e agência: Estrela e DM9DDB

\section{"Tem Mega-Gogo's no Giraffas"}

Representação nº 098/10, julgada em maio de 2010

Anunciante: Giraffas

"Tim, Nokia e McCann-Erickson - Nokia High School Music"

Representação nº 028/09, julgada em março de 2009

Anunciante e agência: Tim Celular e McCann-Erickson

\section{"Total Spin Brasil - Baby Tunes"}

Representação nº 046/09, julgada em março de 2009

Anunciante: Total Spin Brasil Serviç̧os de Telecomunicações

\section{"Trick Nick, roupa como criança imagina"}

Representação n² 285/09, julgada em dezembro de 2009

Anunciante: Rovitex

"Turner International - Enviando Alien - CN"

Representação n 231/09, julgada em junho de 2010

Anunciante: Turner International (Cartoon Network)

"Turner International - Mande Mac ou Blu - CN"

Representação n 232/09, julgada em março de 2010

Anunciante: Turner International (Cartoon Network)
"União de Lojas Leader - Fantástico mundo da criança"

Representação n 281/09, julgada em novembro de 2009

Anunciante: União de Lojas Leader

"Universal Music - CD A Casa Amarela"

Representação nº 374/08, julgada em abril de 2009

Anunciante e agência: Universal Music e Complô Produções

"Vaidosa - Cotiplás Brinquedos"

Representação n 259/09, julgada em março de 2010

Anunciante: Cotiplás

\section{"Vídeo Game WI Vision"}

Representação nº 066/08, julgada em maio de 2008

Anunciante: Eletrolog

"Volta às aulas com seus ídolos Le Postiche"

Representação nº 034/10, julgada em julho de 2010

Anunciante e agência: Le Postiche Indústria e Comércio e Fabra Quinteiro TSM

\section{MERCHANDISINC}

\section{“Danoninho"}

Representação n 337/08, em recurso ordinário, julgada em dezembro de 2008 Anunciante: Danone

\section{"Mc Donald's - Naruto"}

Representação nº 097/10, julgada em junho de 2010

Anunciante: McDonald's

"Merchandising Selvagem - Programa Pânico na TV"

Representação n 134/10, julgada em setembro de 2010

Anunciante: Ind. e Com. de Bebidas Rodrigues e Silva

\section{"Papinhas Nestlé"}

Representação n 409/08, julgada em março de 2009

Anunciante: Nestlé

"Pepsico e Turner International - Toddynho"

Representação n 431/08, julgada em março de 2009

Anunciantes: Pepsico e Turner International

"Skol"

Representação nº 036/09, em recurso ordinário, julgada em maio de 2009

Anunciante: MTV Brasil e AmBev

\section{CONSUMO RESPONSÁVEL E HÁBITOS SAUDÁVEIS}

\section{"Activia - Criança pode"}

Representação no 144/11, julgada em julho de 2011

Anunciante e agência: Danone e Young\&Rubicam

\section{"Café Pilão"}

Representação n 189/10, julgada em setembro de 2010

Anunciante e agência: Sara Lee Cafés do Brasil e AlmapBBDO

\section{"Candide - Xuxa"}

Representação n 327/07, julgada em março de 2008

Anunciante: Candide Indústrias

\section{"Danoninho - Opinião do pediatra"}

Representação n 236/07, em recurso ordinário, julgadas em setembro 2007 e fev. 2008

Anunciante e agência: Danone e Young \& Rubicam 
“Dia das Crianças 3x melhor - C\&A"

Representação n 010/11, julgada em julho de 2011

Anunciante: C\&A Modas

\section{"Dolly Verão 2011"}

Representação nº 040/11, julgada em maio de 2011

Anunciante: Dettal

\section{"Enviando desafio - CN Celular"}

Representação n 206/09, julgada em novembro de 2009

Anunciante: Turner International do Brasil (Cartoon Network)

\section{“Enviando mix para 77888 - CN"}

Representação n 233/09, julgada em novembro de 2009

Anunciante: Turner International do Brasil (Cartoon Network)

\section{"Hot Wheels - Desafio"}

Representação no 118/11, julgada em setembro de 2011

Anunciante e agência: Mattel e Age

\section{"Kellogg - Sucrilhos prepare-se para ser fera"}

Representação n 1 156/09, julgada em setembro de 2009

Anunciante: Kellogg do Brasil

\section{“Kyly - Vai querer o quê?”}

Representação n 257/06, julgada em dezembro de 2006

Anunciante e agência: Malhas Kyly e Rái Assessoria e Comunicação

\section{"Mande Toon para 49218"}

Representação nº 234/09, julgada em novembro de 2009

Anunciante: Turner International (Cartoon Network)

\section{"Ministério da Agricultura - 0 incrivel café"}

Representação n 372/10, em recurso ordinário, julgada em outubro de 2011

Anunciante e agência: Ministério da Agricultura e SLA Propaganda

\section{"Nescau Nutri Júnior"}

Representação nº 299/08, julgada em julho de 2009

Anunciante: Nestle

\section{"PB Kids - Natal"}

Representação n 318/11, julgada em maior de 2012

Anunciante: PBK Kids Brinquedos

\section{"Playphone - Envie"}

Representação nº 203/09, julgada em novembro de 2009

Anunciante: Playphone

"Primo Schincariol - Toda família tem: um moleque muito folgado" Representação nº 408/08, em recurso ordinário, julgada em agosto de 2009

Anunciante: Schincariol

\section{"Promoção é hora de Shrek"}

Representação n 205/07, em recurso extraordinário, julgada em junho de 2008 Anunciante: Pandurata Alimentos

\section{"Salgadinhos Cheetos"}

Representação n² 250/11, julgada em novembro de 2011

Anunciante: Pepsico do Brasil

\section{"Sanchez Cano Ltda - Balas Fini"}

Representação n 196/10, julgada em setembro de 2010

Anunciante: Sánchez Cano (Balas Fini)
"Sustagen Kids - Fortalece a saúde de seu filho"

Representação n 259/07, julgada em novembro de 2007

Anunciante e agência: Bristol Myers Squibb e F/Nazca

\section{"Tilibra - Na lábia"}

Representação n 136/07, julgada em julho de 2007

Anunciante e agência: Tilibra e Talent

“Turner International do Brasil (Cartoon Network) - Envie nojo para 77888 - CN"

Representação n 230/09, julgada em dezembro de 2009

Anunciante: Turner International (Cartoon Network)

"VR Medical Importadora e Distribuidora de Produtos Médicos - Pointts Sistema de eliminação de verrugas"

Representação n 120/10, julgada em setembro de 2010

Anunciantes: VR Medical Importadora e Distribuidora de Produtos Médicos (Pointts)

\section{RESPONSABILIDADE SOCIAL}

\section{COMPORTAMENTO PERIGOSO}

\section{"Brinque com fogo. Burn Energy Drink"}

Representação n 347/10, julgada em maio de 2011

Anunciante: Recofarma

\section{"Burger King - A gente faz do seu jeito"}

Representação n 346/08, julgada em abril de 2009

Anunciante: Burger King

\section{"Cartoon Network - Meninas Super Poderosas"} Representação n0 088/09, julgada em maio de 2009

Anunciante: Turner International

\section{"Chegou Blopens"}

Representação nº 009/08, julgada em maio de 2008

Anunciante: Grow Jogos e Brinquedos

\section{"Claro - A vida na sua mão"}

Representação n 057/08, em recurso ordinário, julgada em setembro de 2008 Anunciante e agência: Claro e AlmapBBDO

\section{"Claro - V3 Black"}

Representação n 194/06, julgada em novembro de 2006

Anunciante e agência: Claro Empresas e F/Nazca

\section{“Dia dos Fuzarkas Renner"}

Representação nº 349/08, em recurso ordinário, julgada em fevereiro de 2009 Anunciante: Lojas Renner

\section{“Diesel - Live Fast (Bebê)"}

Representação n 274/08, em recurso ordinário, julgada em setembro de 2010 Anunciante: Diesel

\section{"Fnac Kids"}

Representação nº 245/11, julgada em novembro de 2011

Anunciante: Fnac Brasil

\section{"Freegells Love Cats"}

Representação n 176/07, julgada em novembro de 2007

Anunciante: Riclan 


\section{"Garagem S/A - É de arrepiar"}

Representação n 279/10, julgada em setembro de 2011

Anunciante: Candide

\section{"Glade - Pedrinho"}

Representação n 1 122/07, em recurso ordinário, julgada em julho e agosto de 2007

Anunciante e agência: Ceras Johnson e Giovanni FCB

\section{"Grendene - Óculos e papete do Homem-Aranha"}

Representação n 256/06, em recurso ordinário, julgada em nov. de 2006 e março de 2007

Anunciante e agência: Grendene Sobral e W/Brasil

\section{"Hot Wheels"}

Representação No 275/08, julgada em setembro de 2008

Anunciante: Mattel do Brasil

\section{"Justiça Eleitoral - Abelha"}

Representação n 320/08, julgada em novembro de 2008

Anunciante e Agência: Tribunal Superior Eleitoral e W/Brasil

\section{“Longe - Panettone Bauducco"}

Representação n 309/11, julgada em maio de 2012

Anunciante e agência: Pandurata Alimentos e AlmapBBDO

\section{"Mês das tintas Telha Norte"}

Representação no 136/10, julgada em novembro de 2010

Anunciante e agência: Telha Norte e DM9DDB

\section{"Motorola U6"}

Representação nº 062/07, julgada em maio de 2007

Anunciante e agência: Motorola e Ogilvy Brasi

\section{“Nescau - Qual é o seu limite?"}

Representação no 104/11, julgada em julho de 2011

Anunciante: Nestlé

\section{“Nova bala mastigável Halls"}

Representação n² 294/06, julgada em março de 2007

Anunciante e agência: Cadbury Adams Brasil e J. Walter Thompson

\section{“Novo Uno - Bebê"}

Representação n 177/10, em recurso ordinário, julgada em maio de 2011

Anunciante e agência: Fiat e Leo Burnett

\section{"Papete do Homem Aranha"}

Representação n 244/07, julgada em setembro de 2007

Anunciante e agência: Grendene e W/Brasil

\section{"Para um amanhã mais saudável, Yakult hoje"}

Representação nº 074/11, julgada em novembro de 2011

Anunciante e agência: Yakult e GP 7

\section{"S.0.S. Mata Atlântica”}

Representação nº 038/08, julgada em julho de 2008

Anunciante: Fundação S.O.S. Mata Atlântica

\section{"Sandero, o Renault que você não esperava"}

Representação nº 084/08, julgada em maio de 2008

Anunciante e agência: Renault e Neogama BBH

\section{"SBP Automático"}

Representação n 327/09, em recurso ordinário, julgada em julho de 2010

Anunciante: Reckitt Benckiser

\section{"Shopping Praiamar"}

Representação n 329/09, julgada em maio de 2010

Anunciante: Condomínio Shopping Center Praiamar

\section{"Skol - Tubarão"}

Representação no 183/11 e nº 184/11, julgada em novembro de 2011

Anunciante e agência: Ambev e F/Nazca S\&S

"Skol - Um por todos e todos por uma"

Representação nº 070/11, julgada em maio de 2011

Anunciantes e agência: Ambev e CBB e F/Nazca

\section{"Sky. TV é poder interagir"}

Representação n 365/08, julgada em dezembro de 2008

Anunciante e agência: Sky Brasil e Giovanni FCB

\section{"Supermercado Condor"}

Representação nº 012/11, julgada em abril de 2010

Anunciante e agência: Supermercado Condor e CCZ Comunicação

\section{"Tang - Preparou, bebeu, faz"}

Representação nº 318/09, julgada em março de 2010

Anunciante e agência: Kraft Foods Brasil e Ogilvy

“Telefônica - Muito inteligente"

Representação nº 095/11, julgada em julho de 2011

Anunciante e agência: Telefônica e DM9DDB

\section{COMPORTAMENTO DESEDUCATIVO}

\section{"A gente faz o que quer"}

Representação nº 077/08, julgada em junho de 2008

Anunciante: Cartoon Network

"Ades Nutri Kids - As escolhas de Marina: primeiro dia de aula" Representação no 162/09, em recurso ordinário, julgada em março de 2010 Anunciante e agência: Unilever Brasil e New Content

\section{"Banco Itaú - Feito para você"}

Representação n 307/07, julgada em abril de 2008

Anunciante e agência: Banco Itaú e DM9DDB

\section{"Bis Avelä"}

Representação n 248/09, julgada em novembro de 2009

Anunciante e agência: Kraft Foods e Ogilvy \& Mather

\section{"Cadernos Tilibra"}

Representação n 012/08, julgada em maio de 2008

Anunciante: Tilibra

\section{"CBL - Cola maluca"}

Representação n 160/10, julgada em setembro de 2010

Anunciante e agência: Cola Maluca e Adyel Figueiredo Maia

\section{"Chamyto - Nestlé"}

Representação nº 045/12, julgada em maio de 2012

Anunciante e agência: Nestlé e Giovanni+DraftFCB

\section{"Chocolate Bis - Sala de aula"}

Representação no 189/07, julgada em setembro de 2007

Anunciante e agência: Kraft 


\section{"Chokito - Vai um aí?"}

Representação n² 234/06, julgada em novembro de 2006

Anunciante e agência: Nestlé e J. Thompson

\section{"Diário Popular - Biblioteca Larousse"}

Representação n² 285/07, julgada em novembro de 2007

Anunciante: Diário de São Paulo

\section{"Ecosport - Bichinhos"}

Representação n 1 159/07, julgada em novembro de 2007

Anunciante e agência: Ford e J. Walter Thompson

\section{"Família - Sadia”}

Representação n 292/09, julgada em março de 2010

Anunciante e agência: Sadia e DPZ

\section{"Ford - Viva o novo"}

Representação n 072/08, julgada em julho de 2008

Anunciante e agência: Ford e J. Walter Thompson

\section{"Globo.com - Big Brother Brasil 10"}

Representação n 027/10, julgada em março de 2010

Anunciante: Globo.com

\section{"Gulliver - Incrível Hulk"}

Representação no 426/08, julgada em agosto de 2009

Anunciante: Gulliver

\section{"Havaianas - Avó"}

Representação n 238/09, julgada em novembro de 2009

Anunciante e agência: São Paulo Alpargatas e AlmapBBDO

"Itaú - A todos vocês, muito obrigado"

Representação n 324/10, julgada em março de 2011

Anunciante e agência: Banco Itaú e África

\section{"Itaú Personalité - Lambari"}

Representação n 152/06, julgada em setembro de 2006

Anunciante e agência: Banco Itaú e DPZ

\section{“Leader - Já é Dia das Mães”}

Representação nº 129/07, julgada em julho de 2007

Anunciante e agência: União de Lojas Leader e Matos Grey Comunicação

\section{"Mattel - Pista Hot Wheels - Vai encarar?"}

Representação n 439/08, julgada em março de 2009

Anunciante: Mattel do Brasil

\section{"Mega Shot"}

Representação n 427/08, julgada em março de 2009

Anunciante e agência: New Toys e Trade Editoração

\section{"Nem a pau, Juvenal"}

Representação nº 189/08

Anunciante e agência: Sadia e DPZ

\section{"Nerf - Hasbro"}

Representação n² 290/10, julgada em novembro de 2010

Anunciante: Hasbro Brasil

\section{"Nerf - Hasbro"}

Representação n 313/10, julgada em novembro de 2010

Anunciante: Hasbro Brasil
"Net - Todo mundo está saindo da Sibéria”

Representação nº 067/09, em recurso extraordinário, julgada em outubro de 2010 Anunciante: Net Serviços de Comunicação

"Novo Dove Men Care"

Representação n 184/10, julgada em novembro de 2010

Anunciante: Unilever Brasil

\section{"Novo Fiat Punto"}

Representação nº 222/10, julgada em outubro de 2010

Anunciante e agência: Fiat Automóveis e Leo Burnett

\section{"Omo multiação tanquinho"}

Representação n 127/10, julgada em setembro de 2010

Anunciante e agência: Unilever Brasil e Neogama BBH

"Pode falar de boca cheia: Mortadela é Marba" Representação nº 213/06, julgada em outubro de 2006 Anunciante: Frigorífero Marba

"Quem não assina SKY por RS 69,90 é muito pamonha" Representação nº 029/10, em recurso ordinário, julgada em julho de 2010 Anunciante e agência: Sky Brasil e Giovanni FCB

"Reckitt Benckinser - Mortein Rodox, a força que protege" Representação nº 424/08, julgada em março de 2009 Anunciante: Reckitt Benckiser

\section{"Reckitt Benckiser - Repelex Kids"}

Representação nº 030/10, julgada em maio de 2010 Anunciante: Reckitt Benckiser

"Red Bull - Chapeuzinho Vermelho"

Representação no 101/10, julgada em maio de 2010

Anunciante: Red Bull

"Renault - Depois do Stepway, ladeira é drop. E outros carros são flat" Representação n 115/10, julgada em setembro de 2010

Anunciante e agência: Renault do Brasil e Neogama

\section{“Roma Tático Blindado"}

Representação n 247/10, julgada em novembro de 2010

Anunciante: Roma Jensen Comércio e Indústria

\section{"Sadia, a vida com S é mais gostosa"}

Representação n 202/09, julgada em novembro de 2009

Anunciante: Sadia

\section{"Samsung - Por acaso está escrito na minha testa?"} Representação no 132/07, julgada em julho de 2007

Anunciante e agência: Samsung Brasil e J. Walter Thompson

\section{"Seda Teens"}

Representação nº 045/08, julgada em maio de 2008

Anunciante: Unilever Brasil

\section{"Skol - Pagando mico"}

Representação n 311/09, julgada em março de 2010

Anunciante e agência: AmBev e F/Nazca S\&S

\section{"Sky - Abaixo-assinado"}

Representação n 174/06, julgada em setembro de 2006

Anunciante e agência: Sky e Neogama 


\section{"Sky TV é isso"}

Representação n 075/08, julgada em julho de 2008

Anunciante: Sky Brasil

\section{“Space Cross - VW"}

Representação n 222/11, julgada em novembro de 2011

Anunciante e agência: VW e Almap/BBDO

\section{"Sprite Zero - As coisas são como elas são II"} Representação n 108/07, julgada em junho de 2007

Anunciante e agência: Coca-Cola Indústrias e McCann Erickson Publicidade

\section{"Sucos Camp - Vaso" e "Sucos Camp - Boletim"}

Representação no 179/07, julgada em novembro de 2007

Anunciante: General Brands do Brasil

\section{"Tortuguita"}

Representação n² 242/08, em recurso ordinário, julgada em julho de 2009

Anunciante: Arcor do Brasil

\section{"Trakinas, o ovo de Páscoa que é a minha cara"}

Representação nº 065/08, julgada em maio de 2008

Anunciante e agência: Kraft Foods e Giovanni, FCB

“Turner International - Você também pode jogar com o seu celular. CN Celular"

Representação n 319/09, julgada em março de 2010

Anunciante: Turner International (Cartoon Network)

\section{"Unilever - Família Bernardinho"}

Representação n 276/07, julgada em novembro de 2007

Anunciante e agência: Unilever e Ogilvy

\section{"Vanish Poder 02 com até 10 x mais oxigênio"}

Representação n 1 194/10, julgada em agosto de 2010

Anunciante: Reckitt Benckiser Brasil

\section{"Vanish Poder 02"}

Representação nº 117/09, em recurso ordinário, julgada em setembro de 2009 Anunciante e agência: Reckitt Benckiser e Euro RSCG Brasil

\section{"Vírgula - Baixa Hits"}

Representação nº 343/08, julgada em maio de 2009

Anunciante: Vírgula

"Vivo - Conexão como nenhuma outra"

Representação nº 019/10, julgada em maio de 2010

Anunciante: Vivo

\section{"Xixi no banho - S.O.S. Mata Atlântica"}

Representação nº 048/10, julgada em julho de 2010

Anunciante: Fundação S.O.S. Mata Atlântica

\section{ESTÍMULO AO CONSUMISMO}

\section{"Casa Pio - Vamos para Casa Pio"}

Representação n 380/08, julgada em abril de 2009

Anunciante: Casa Pio Calçados

\section{"Grendene - Xuxa - Cuidar da natureza"}

Representação n 330/09, em recurso ordinário, julgada em julho de 2010

Anunciante: Grendene

\section{"Lap Top da Xuxa - Candide"}

Representação n 357/10, julgada em março de 2011

Anunciantes: Candide

\section{“Mattel - Polly Pocket"}

Representação n⿳ 162/08, julgada em setembro de 2008

Anunciante: Mattel do Brasil

\section{"McDonalds - McBacon Junior"}

Representação nº 044/07, julgada em maio de 2007

Anunciante e agência: McDonalds e Taterka Comunicações

\section{"Mundo do Sítio na TV"}

Representação no 182/11, julgada em novembro de 2011

Anunciante: Editora Globo

"Playarte Kids - Peça agora mesmo para o papai e para a mamãe" Representação n 423/08, julgada em março de 2009

Anunciante: Playarte Pictures

\section{"Purina Dog Chow - Incrível para a vida"}

Representação n 171/07, em recurso ordinário, julgada em novembro de 2007 Anunciante: Nestlé - Divisão Purina

\section{"Samsung Celular Beat Mix - Princesa"}

Representação nº 316/10, em recurso ordinário, julgada em março de 2011

Anunciante: Samsung

\section{PRECONCEITO}

"CD da Whitney Houston - Som Livre"

Representação nº 024/08, julgada em maio de 2008

Anunciante: Som Livre

"Toda família tem refrigerante Schin - Primo"

Representação n 326/08, julgada em março de 2009

Anunciante e agência: Primo Schincariol e Lew Lara

\section{RESPEITABILIDADE}

"Blaupunkt - The advantage in your car" Representação n² 225/06, julgada em dezembro de 2006 Anunciante: Blaupunkt - Robert Bosch

"Boate Parthenon - Night club show"

Representação n 244/09, julgada em novembro de 2009

Anunciante: Boate Parthenon

\section{“Bubballoo - É sempre uma charada"}

Representação n² 241/06, julgada em dezembro de 2006

Anunciante e agência: Adams Brasil e J. Walter Thompson

\section{"Burger King. Indecente de tão gostoso"}

Representação n 161/08, julgada em março de 2009

Anunciante: Burger King

\section{"Campanha Sol - É ponto"}

Representação n 181/07, julgada em setembro de 2007

Anunciante e agência: Cervejarias Kaiser Brasil e Fischer América

\section{"Claro - Fale quantas vezes quiser"}

Representação n 179/09, em recurso ordinário, julgada em dezembro de 2009

Anunciante e agência: Claro Empresas e F/Nazca S\&S 


\section{"Coca-Cola Zero"}

Representação no 130/07, em recurso extraordinário, julgada em setembro e dezembro de 2007

Anunciante: Coca-Cola

\section{"Desodorante Axe - Salvo pelo twist"}

Representação nº 088/10, julgada em novembro de 2010

Anunciante: Unilever Brasil

\section{"Giraffas"}

Representação nº 004/09, julgada em abril de 2009

Anunciante e agência: Lanchonete Giraffas e DPZ

\section{"Guaraná Kuat"}

Representação n 165/06, julgada em setembro de 2006

Anunciante: Coca-Cola

\section{"GVT - Acorda tio"}

Representação nº 016/12, julgada em maio de 2012

Anunciante e agência: GVT e Loducca

\section{“Havaianas Kids - Kaiky Brito"}

Representação n 247/06, julgada em novembro de 2006

Anunciante e agência: São Paulo Alpargatas e Almap/BBDO

\section{"Hyundai Santa Fé - A nova geração chegou"}

Representação no 144/07, julgada em setembro de 2007

Anunciante e agência: Hyundai e Z+

\section{"Ketchup Hellman's - Tarados por Ketchup"}

Representação n² 243/06, julgada em dezembro de 2006

Anunciante e agência: Unilever e Ogilvy Brasil

\section{"Kuat - Mãe do amigo"}

Representação n 294/10, julgada em novembro de 2010

Anunciante: Coca-Cola

“Lojas Renner - Dia dos Namorados. Presentes cheios de segundas intenções"

Representação n 167/10, julgada em agosto de 2010

Anunciante: Lojas Renner

\section{"Marisol - Use e se lambuze"}

Representação n 144/08, em recurso ordinário, julgada em setembro de 2008 Anunciante: Marisol

\section{"Os cafajestes - Uma comédia musical"}

Representação n 344/08, julgada em novembro de 2008

Anunciante: Teatro das Artes

"Palmolive - Sua beleza começa na pele"

Representação n 093/08, julgada em junho de 2008

Anunciante e agência: Colgate-Palmolive e Y\&R Propaganda

\section{"Pânico Energy Drink - É ligação direta"}

Representação nº 080/10, julgada em julho de 2010

Anunciante: Alternativa Comércio de Bebidas e Alimentos

\section{"Prazer começa com Prudence"}

Representação nº 047/10, julgada em maio de 2010

Anunciante: DKT do Brasil

\section{"Protex Própolis"}

Representação n 175/08, julgada em setembro de 2008

Anunciante: Colgate-Palmolive
"Red Bull - Banco"

Representação no 190/11, julgada em setembro de 2011

Anunciante: Red Bull

"Red Bull - Menino"

Representação n 128/09, julgada em julho de 2009

Anunciante e agência: Red Bull e Loducca

"Red Bull - Praia de nudismo"

Representação no 130/09, julgada em setembro de 2009

Anunciante e agência: Red Bull e Loducca

\section{"Renault Symbol"}

Representação n 171/09, julgada em setembro de 2009

Anunciante e agência: Renault e Neogama

"Revista Capricho - Não precisa explicar. A gente se entende" Representação n² 228/06, julgada em maio de 2007

Anunciante: Editora Abril

\section{"Sergio K"}

Representação nº 062/11, julgado em junho de 2011

Anunciante: SLKS Comércio de Artigos de Moda

"Sprite - As coisas são como são"

Representação nº 059/07, em recurso ordinário, julgada em maio e julho de 2007 Anunciante e agência: Coca-Cola e McCann-Erickson

\section{"Tjnet - Dança do créu"}

Representação n 342/08, julgada em novembro de 2008

Anunciante e agência: Arvato Móbile e Binder Comunicação

\section{"Toddy - Chocolates do mundo"}

Representação nº 064/09, em recurso ordinário, julgada em setembro de 2009 Anunciante: Pepsico

\section{"Trident Rio-nudista"}

Representação no 103/11, julgada em julho de 2011

Anunciante e agência: Kraft Foods e J. Walter Thompson

"Trifil Infantil"

Representação no 157/07, julgada em julho de 2007

Anunciante: Scalina - Trifil

"Verão Bala Gang"

Representação nº 290/07, julgada em maio de 2008

Anunciante: Gang Comércio de Vestuário

\section{CRIANCAS E ADOLESCENTES EM PUBLICIDADE PARA ADULTOS}

\section{USO DE ELEMENTOS DO UNIVERSO INFANTIL}

\section{"Bic Mangá"}

Representação nº 313/07, julgada em abril de 2008

Anunciante: Bic Brasil

\section{"Birinight 6.0"}

Representação nº 295/06, julgada em março de 2007

Anunciante: Indústria e Comércio de Bebidas Imperial 


\section{"Birinight"}

Representação n² 240/06, julgada em dezembro de 2006

Anunciante: Indústria e Comércio de Bebidas Imperial

\section{"Disney Spunch Cereser"}

Representação nº 061/11, julgada em outubro de 2011

Anunciante: Viti Vinícola Cereser

\section{"Mc Lanche Feliz - Rio"}

Representação no 085/11, em recurso ordinário, julgada em setembro de 2011 Anunciante e agência: McDonald's e Taterka

\section{"Mega aniversário Carrefour"}

Representação n² 216/09, julgada em novembro de 2009

Anunciante: Carrefour

\section{"Merchandising Brahma tampinha"}

Representação n 217/09, em recurso ordinário, julgada em março de 2010

Anunciante: AmBev

\section{"Misteriosa mistura de Skol com limão"}

Representação nº 056/07, em recurso ordinário, julgada em julho de 2007

Anunciante: AmBev

\section{"Nissan Frontier - Pôneis malditos"}

Representação no 176/11, julgada em setembro de 2011

Anunciante e agência: Nissan e Lew' Lara/TBWA

\section{"Saia do óbvio, Xingu"}

Representação n ${ }^{\circ}$ 139/08, julgada em agosto de 2008

Anunciante e agência: Kaiser e Talent

\section{"Skol - Fantasiados"}

Representação n 016/07, em recurso ordinário, julgada em março e maio de 2007

Anunciante e agência: Ambev e F/Nazca

\section{"Skol - Monstro do Pântano"}

Representação nº 024/11, julgada em setembro de 2011

Anunciante e agência: Ambev e F/Nazca S\&S

\section{"Vodka Absolut"}

Representação n 102/10, em recurso ordinário, julgada em julho de 2011

Anunciante: Pernod Ricard

\section{VOCALIZAÇÃO DE APELO DE CONSUMO POR CRIANÇAS}

\section{"A minha Páscoa é Carrefour"}

Representação n 082/08, julgada em julho de 2008

Anunciante e agência: Carrefour e Almap/BBDO

\section{"Anador - Contra dores de cabeça, dores nas costas..."}

Representação nº 008/08, julgada em março de 2008

Anunciante e agência: Boehringer Ingelheim e Leo Burnett

\section{"Brinquedo é no Magazine Luiza"}

Representação n² 249/09, julgada em novembro de 2009

Anunciante: Magazine Luiza

\section{"Claro - 0 meu também"}

Representação n 336/09, julgada em março de 2010

Anunciante e agência: Claro e AlmapBBDO
"Eu quero games foto MP3!!! Seu filho quer celular da C\&A"

Representação nº 354/08, em recurso ordinário, julgada em março de 2009

Anunciantes: C\&A e Claro

\section{"Extra, o hipermercado da minha família"}

Representação n 264/07, em recurso ordinário, julgada em nov. 2007 e março de 2008

Anunciante e agência: Extra e P.A. Publicidade

\section{"Lysoclin"}

Representação n 026/08, julgada em julho de 2008

Anunciante e agência: e Nobel do Brasil e Del Grappa

"Não faça da sua família um prato cheio para os pernilongos" e "Raid Protecto. Eficácia que protege"

Representações n 016/08 e 018/08, julgadas em maio de 2008

Anunciantes: Sul Química e Ceras Johnson

\section{"Net Virtua com Mega Flash"}

Representação nº 203/06, julgada em outubro de 2006

Anunciante e agência: Net e Talent

\section{"Ourocard Dia das Crianças"}

Representação n² 235/06, em recurso ordinário, julgada em novembro de 2006 e fevereiro de 2007

Anunciante e agência: Banco do Brasil e Ogilvy BR

"Pai de cara nova com Gilette na Pacheco"

Representação n² 238/06, julgada em novembro de 2006

Anunciante e agência: Drogaria Pacheco e Contemporânea

"Pão de Açúcar - Lugar de gente feliz"

Representação nº 086/08, em recurso extraordinário, julgada em fevereiro de 2009 Anunciante e agência: Pão de Açúcar e P. A. Publicidade

\section{"Prezunic - É o que você quer"}

Representação n² 200/07, julgada em setembro de 2007

Anunciante: Supermercado Prezunic

"Sundown Kids. Ultraproteção para a pele sensível das crianças" Representação n 017/10, julgada em março de 2010 Anunciante: Johnson \& Johnson

\section{"Sustagen Kids"}

Representação nº 013/08, julgada em maio de 2008

Anunciante: Bristol Meyers Squibb

\section{CREDULIDADE INFANTIL}

"Barbie Fashionistas Luzes"

Representação n 310/11, julgada em maio de 2012

Anunciante: Mattel do Brasil

\section{IDADE DE MODELOS}

\section{"Skol - Carrinho" e "Skol - Pelado"}

Representação n 132/06, em recurso ordinário, julgada em setembro de 2006 Anunciante e agência: Ambev e F/Nazca

\section{"Skol - Golfe"}

Representação nº 033/08, julgada em junho de 2008

Anunciante e agência: AmBev e F/Nazca 
Tudo o que você precisa saber sobre o Conar,

sua história, membros, funcionamento, decisões e formas de participação está no site www.conar.org.br

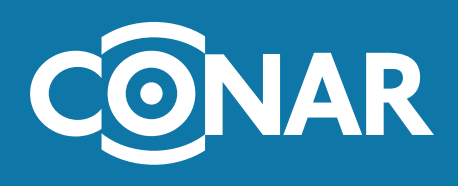

CONSELHO NACIONAL DE AUTORREGULAMENTAÇÃO PUBLICITÁRIA

Agosto de 2012 